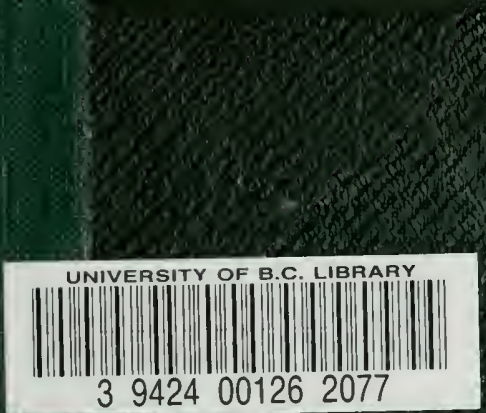

STCRAGE ITEM FRCCESSING-ONE

I p 1- $19 \mathrm{~F}$ U.B.C. LIBRARY 


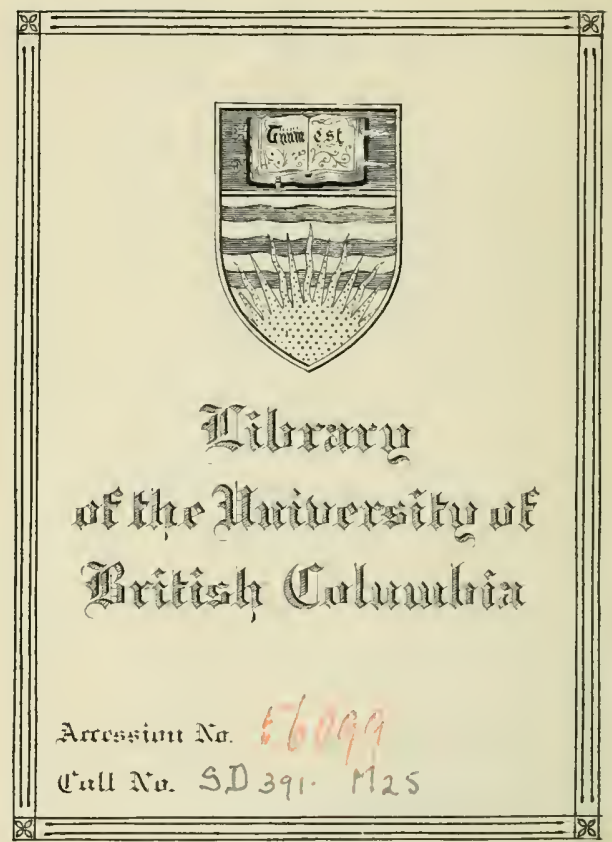


Digitized by the Internet Archive in 2010 with funding from University of British Columbia Library 


$$
\text { ye 4. }
$$

(2) 


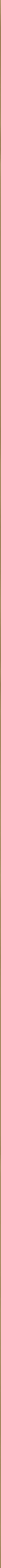


\%.

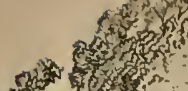

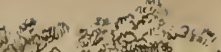

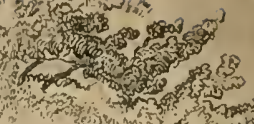

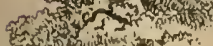

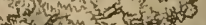

Eil

- 4 .

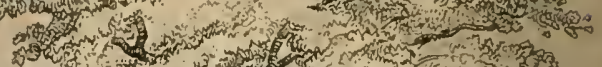

oren

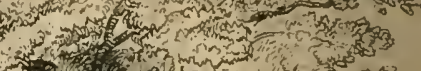

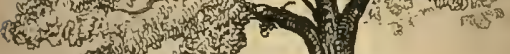

( )
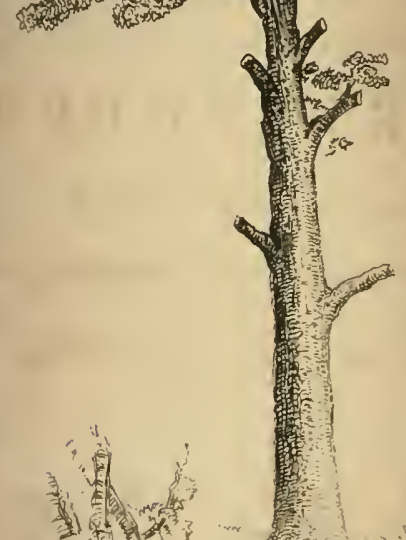

Q

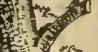

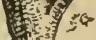

進:
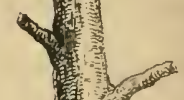

Tis

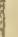

40325

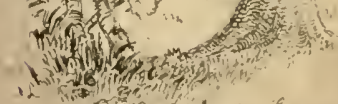

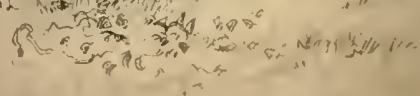




\section{THE \\ FOREST PLANTER AND PRUNER'S \\ ASSISTANT: \\ BEING}

A PRACTICAL TREATISE

ON THE

MANAGEMENT OF THE, ;

NATIVE AND EXOTIC

F O R E S T T R E S

COMMONLY CULTIVATED IN GREAT BRITAIN ;

RESPECTING WHICH EVERY USEFUL INFORMATION IS GIVEN.

ILLUSTRATED BY ENGRAVED FIGURES.

BY J. MAIN, A.L.S.

LONDON:

R I D G W A Y, P I C C A D I L L Y. 1839. 


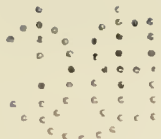

LONDON :

Printed by W. Blatch, Grove Place, Brompton. 


\section{PREFACE.}

Is the following pages it is not intended to notice everything that may be written of forest trees; nor to describe or even name every tree-like plant found in woods. On the general subject there are already extant numerous volumes, many of which are only poetically and pictorially interesting: others are chiefly historical; and others again are simply practical, and confined merely 
to the processes of raising and transplanting trees, with lists of their names.

The scope of the present treatise is intended to embrace descriptions of the more common and most useful species of forest trees only; with practical remarks on their culture and management, and with particular reference to the necessary and important business of pruning them when young, in order to ensure the production of clear-grained and most valuable timber.

The last-mentioned part of a forester's duty has not been studied nor so generally attended to as it deserves; and it is only very lately that definite rules have been laid down for the pruner's guidance. This division of the subject will, therefore, receive full consideration, 
accompanied with illustrations of the effects of pruning in erery stage of the life of a tree; the whole being treated in a brief but comprehensive manner, and in the plainest language. 



\section{CONTENTS.}

\section{CHAPTER I.}

PAGE

Preliminary Remarks.-Aboriginal forests-how destroyed $\rightarrow$ present remains and management

CHAPTER II.

On Planting-different methods of-obstacles in the way of

\section{CHAPTER III.}

On the Defects and Necessity of Pruning-how far practicable-effects and advantages of

\section{CHAPTER IV.}

Suitable Soils for Trees-clay-loam-sand subsoils -moor and bog-earth-wet and dry soils-trees suitable for

\section{CHAPTER V.}

Treatment of Wounded Trees-causes of wounds-topical applications-damage from insects or other animals 


\section{CONTENTS.}

\section{CHAPTER VI.}

PAGE

Qualities of Timber-ponderosity-hardness-toughness-durability-dry-rot-Kyanising . . 147

\section{CHAPTER VII.}

On Coppice Woods-description and value of-management, \&c.-trees suitable for $\quad$. $\quad 177$

\section{CHAPTER VIII.}

On Pruning the Pine and Fir Tribes-why so necessary-evil of neglect-rules for performing . . 188

\section{CHAPTER IX.}

Pollard Trees-their stations and uses-how planted and managed-kinds - 209

\section{CHAPTER $X$.}

Langevity of Trees-information concerning-knowledge of wanting

\section{CHAPTER XI.}

Miscellaneous-felling-grubbing, \&c.

Fencing-absolute necessity of-different methods of-botanical distinctions of trees . . . 231

List of British Forest Trees . . 241 
2

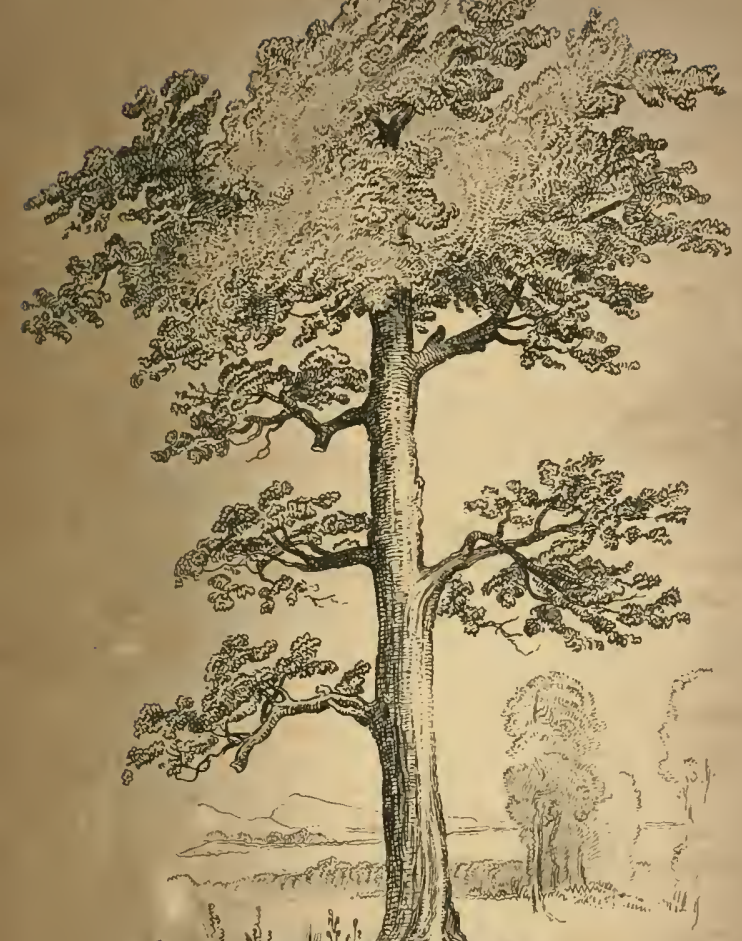

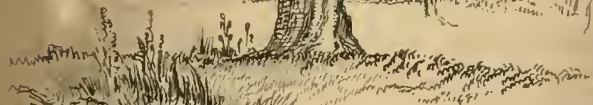

-30 -

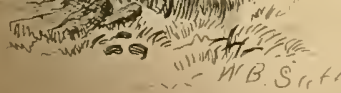





\section{THE}

\section{F 0 R E S T P L A N T E R.}

\section{CHAPTER I.}

PRELIMINARY REMARKS.

Arboriculture, like every other branch of rural economy, continues to be on the improve. Our present experience, added to that of the past, must naturally tend to render all future attempts at planting, when properly ex- 
ecuted, much more certain in their results. The nature of soils, and their effects on the growth of trees, and on the qualities of timber, are now much better understood than heretofore; and the study of physiology and the phenomena of the growth, has enabled the forester to manage his trees so as to give them the finest forms, and, at the same time, yield the most valuable quality of convertible timber.

Many books have been written on this subject, all of which contain much valuable information. 'Those of $\mathrm{Mr}$. Pontey have great merit, but, as his opinions are diffuse, it will not detract from his well-earned fame, nor from that of his followers, if their scattered practical rules and principles be concentrated into a short treatise, ac- 
companied by practical comments and illustrations, to corroborate facts, to clear up obscurities, to rectify errors, and to dismiss all that is redundant or obsolete. Thus reduced, it will be no very serious tax on either the time or purse of the reader, while it may contain all that is really essentially necessary to be known respecting forest trees, whether intended for sources of profit, or as objects of ornament.

The subject is highly and eren nationally interesting; and not only to the landholder, but to every admirer of sylvan scenery. Trees are the principal ornaments of the face of the earth ; their shade is no less grateful under the heat of summer than the shelter they afford against the cold of winter; both so necessary around the habitations of

B 2 
man. Trees add a charm to every landscape, and no landed estate or country residence is deemed either so valuable or beautiful, unless it is well wooded. The useful material which they yield so abundantly for the various purposes of civilized life, are too well known to require notice.

In almost every region of the habitable globe, native woods of some description or other are found, unless they have been cleared away by the hand of man. Some tracts hare been disforested by convulsions of nature, as exemplified in the great desert of Sahara, in Africa, a wide waste of sand, which now overwhelms an extensive expanse of a once rerdant and sylvan champaign. In the same latitudes, howerer, which are free from shifting sand, the natural woods 
are most luxuriant and lofty. As the oldest trees decay, they are succeeded by their own or other seedlings for ever, if man does not interfere to destroy by the axe, or by fire. For such conflagrations often happen, either by design or accident, in uninhabited countries, by which rast tracts of woodlands are laid waste in a few days. Such an awful circumstance as a whole country on fire took place not many years ago in the neighbourhood of Miramichi, in North America, and was attended, not only with the destruction of extensive natural woods, but disastrous to many houses of the inhabitants of the place. The greater part of the continent of America is still covered with indigenous woods; and all farther India and its numerous islands are densely clothed with 
stately timber trees, and thickets of shrubs, or jungle, as it is there called, even to the shores of the sea. And in many, particularly the northern parts, of the old world, we still find the remains of natural woods; and from many evidences in the dark pages of early history, and from the testimony of geological research at the present time, it is more than probable, that the greater part of the continent of Europe, as well as its islands, were at an early period almost entirely covered with wood.

At the time of the invasion of our own island by the Romans, it is clear that from their account of the country, it was very generally, if not wholly covered with wood, except, perhaps, the highest peaks of the hills. And we still see some remains of these vast forests 
which have been reserved by the sovereigns or opulent proprietors for the amusement of the chase, or for the preservation of the timber. Other tracks of natural forest are also in existence, occupying broken or marshy ground, or precipitous slopes inaccessible to the plough.

As civilization proceeded, and as the population increased, the surface of the richest lands were gradually cleared; the largest trees, it is probable, were first felled for building, fencing, and fuel, and their roots grubbed up to make way for the plough, or for extending the pasturage for domesticated flocks and herds.

If we examine those parts of Britain which appear to have been first inclosed, that is, divided into fields for the more 
convenient operations or purposes of husbandry, -it is very evident that the hedges, both as respects the ground they occupy, and their winding directions, were the work of accident rather than design; showing decidedly that the fields were formed out of the forest, rather than that the fences were planted on a surface previously cleared. In such districts the hedge-rows contain trees and bushes, which are evidently the remains of the original forests, and indicate not only the kind of tree that formerly prevailed, but also the nature and quality of the soil best suited to them. The proximity of rivers, or lakes great or small, roads, \&c., fixed the place of the homesteads; and the richest and most level spots adjacent were first disforested. 
In this way, it is likely the face of the country became gradually cleared of its woods; and before coal came into general use, and when fagots and billet were the only fuel, the trees must, while only considered as an encumbrance, have fallen quickly and extensively. And moreorer, when cities and towns, and villages and farmeries were starting up in every quarter, and when ships for war and for commerce were building at every seaport, all tended to thin and demolish the aboriginal forests, and surrender the cleared surface to the various purposes of the husbandman.

These were the circumstances, together with the intention, perhaps, of dislodging the wolves, Robin Hoods, and other lawless freebooters of those days, which operated to divest the country of B 5 
its extensive woods: and the extirpation must have been in many places most complete, or there could not be such extensive tracts of naked country as now exist, as the plains and downs of the south, and the moors of the north of Britain.

This wholesale destruction of the native original forests of this country, though restrained long afterwards by severe laws against wood-stealers, continued without mercy, it would seem, up to a not very distant period, viz. about the year 1540. The population of the country, howerer, increased so rapidly, that every arable acre, and every acre that could be made arable, was required to raise subsistence for the people. Under this call on the agriculture of the kingdom, every uninclosed commonable 
forest was felled and rooted out, reserving only the royal chases, and those belonging to opulent barons, and nearly as they are seen at this day.

These reserved forests, and hedgerows of the inclosed fields, were at last the only sources whence were drawn the supplies constantly required for the royal and merchant's dockyards; and about three or four-score years ago those sources were so much drawn upon, that fears were entertained lest the necessary supplies should altogether cease. These fears were exaggerated by a very general complaint that a great majority of the trees delivered at the yards were found extremely defective and almost useless.

Persons officially connected with government, and many others from feelings of patriotism, began to be alarmed 
at this diminished supply of ship timber. These fears becoming prevalent, a general resolution was taken to provide a remedy. This was, by adopting a more effectual plan for protecting the still existing woods, and replanting those which had been so severely thinned. The Conmissioners of Woods and Forests earnestly adopted improving the government forests by replanting, and by a great number of private individuals on their own estates; calling forth a host of commercial nurserymen and professional planters in every quarter of the kingdom, by whom thousands of acres of old forest land have been replanted, and immense extents of new wood hare been establisher for the future demands of the country.

The natural woods of Britain are 
either oak or beech, Scotch fir, or birch. The two last are chiefly met with on steep declivities or on moist or rocky ground in the northern counties. The oak occurs on almost every piece of waste or broken ground where the soil is loam or clayey; the beech inhabits the Chiltern or chalky hills of the south; and there are some pieces of uninciosed forests of a mixed character.

Birch woods are but little preserved ol regarded for the timber they yield. It is chiefly used by turners and for some other minor purposes; perishable when exposed to the weather, but durable when kept perfectly dry. Birch is, however, mostly kept as underwood, and cut at periods of from five to ten years' growth; at this age it is convertible into many useful rural purposes. 
Beech woods consist of full-grown or growing timber trees and underwood. The latter is felled periodically, and used for fuel, and for the manufacture of charcoal.

Some of these natural woods, in order to get ricl of the claim of tithes, are suffered to grow up into timber, and beautiful and valuable possessions they ultimately become; the largest trees being gradually drawn for sale, giving space for young seerllings to rise in their place, to which succession there is no natural end, provided the woods are well fenced against the inroads of cattle.

The remains of aboriginal oak woods are still met with in many places, and they are of various character, according to the management they have received. Some of them are on unin- 
closed commons, upon which many of the surrounding residents have equal privileges to eut and carry away. Such woods are only an assemblage of low stunted bushes, very few of the trees being allowed to grow up into timber. Others are on wet clayey soils treated as underwood, with a sprinkling of trees intermixed, and which are occasionally felled for sale when they have arrived at a saleable size. On other such inclosed portions of natural oak wood, the owners prefer timber to mere brush or coppice, and allow as many trees to rise as is consistent with their thriving individually. These in time become lofty and valuable groves, and a source of constant though not annual income to the proprietor.

After a fall made in such permanent 
oak woods, the roots remaining in the ground, throw up during the next and following years a numerous birth of young shoots, which should be thinned periodically and treated in the same way as young trees. These shoots are first thinned in the second or third year by slipping (not cutting) off all redundant growths, leaving three or four of the strongest on each stool. These are.allowed to grow up together till they become too thick, when a half or a third of these wavers are removed for sale. This thinning is continued until one only remains to attain its most saleable bulk.

The oak is a purely indigenous British plant, and no tree increases itself by its seeds with more facility. This tendency to increase its numbers by the 
accidental dispersion of acorns, has been considered so effectual for keeping up a supply of young oak trees in the royal forests, that preserving white and black thorns, brambles, and the like, was by some of the commissioners deemed quite as sufficient for continuing a full stock of trees, as by the means of transplanting. And it is quite true that where there is an undergrowth of bushes to protect the seedlings from cattle, young trees will certainly rise, and, if permitted, grow up rapidly if on deep loamy, or clay soil. Indeed, it is very generally believed that self-sown oak arrives sooner at perfection both in bulk and quality of timber, than trees which have been at any time transplanted. This, though a very natural supposition, is not invariably true; because it has been proved in a thousand 
instances, that as fine transplanted oak has been reared and felled as ever has been procured from self-sown trees.

The supposition alluded to has been founded on the necessity of keeping the first downright, or tap-root, entire. But, however necessary this first root may be to the plant in the early stages of its growth, as well in fixing the tree in its place, as in its descending into the firm and moister subsoil, it must be admitted that the tap-root is sooner or later the very first root which fails, and in all full-grown trees is dead and gone long before the tree arrives at its full stature.

So much importance, however, has been attributed to the preservation of the tap-root of transplanted trees, that its destruction has been imagined as the sole cause of the inferiority of much of 
the oak timber lately used in the dockyards ; and, moreover, that to this mutilation is attributable the liability of the timber to the attack of the dry-rot! This is a mere stretch of fancy; as no proof of any such consequences has ever yet been had : nor is it at all consistent with what is well known concerning the constituents of a trunk of a tree.

Natural woods of ash are not frequent: though a hardy native, or at least long naturalized, and readily increasing itself by seeds, it is mostly thinly scattered among oaks, or other deciduous trees. One reason may be, perhaps, that the poles or wavers are more generally useful for rural purposes than any other sort of tree; and, therefore, is mostly kept as coppice, or in hedge-rows, where, however, this kind of 
tree should never be admitted or allowed to grow, because of its deleterious effects upon corn or grass lands. Ash timber is an excellent material for many purposes in the construction of carriages; but although it grows on rich soils to a noble size, it is not naturally a long-lifed tree. The first and most central roots soon decay; and, consequently, the middle of the bole begins to decay also from the bottom upwards; while, at the same time, the outside of the bole being fed by the horizontal fringe of roots, which always run just within the surface, continues to increase, not being at all affected by the failure at the centre. An ash tree, however rigorous and healthy, should not be allowed to stand, except for ornament, after it has attained twenty inches in diameter. 
Native woods of Scotch fir or pine still exist abundantly in the northern parts of the continent of Europe, and also in the highland districts of the north of Scotland. They have covered the same tracts of country for ages; and whence have been drawn the vast supplies of yellow deal which are every year employed in house-building and other purposes, for which this excellent kind of timber is so well adapted. Its durability depends entirely on the inexhalable and preserrative nature of its resinous sap, and to the cellular structure of the wood being so densely charged with it in a concreted state. Trees of all stages of growth compose these natural woods; seedlings constantly rising, if permitted, under the shelter of the parent trees; and accord- 
ing as they stand close or farther apart from each other, so is the length of bole, and clear-grained quality of their convertible bulk, more or less prized.

It has been said that British deal is very inferior to that grown on the shores of the Baltic. The fact is, perhaps, that if both were grown on the same description of soil, and both were allowed to stand the same number of years, very little difference in quality would be observable. It has been pretty well ascertained that old specimens felled in the north of Scotland, and even such as have stood for a century in the south of England, turn out in no respect inferior to yellow deal imported from Memel or Riga. It is also at the same time quite true, that where the Scotch pine has been planted in rich 
trenched soils in this country, and has risen rapidly into bulk, and then been felled, the timber is porous, and of no great value, as it has neither the solidity nor weight of that of foreign pine, owing entirely to its quicker growth in a warmer climate, or at least where the winters are shorter and less severe.

This circumstance has given rise to a question whether slow or quick-grown timber turns out the most durable when put to use. It would appear that in the case of the different sorts of pine timber which have been used by the carpenter, the outsides of each of the concentric layers composing the wood are more durable than the inner or porous part. This is very apparent on deal tables, floors, or stairs which have been long used; and hence it has 
been argued, that the closer these outer rims are to each other-in other words, the slower the growth-the more solid, and consequently the more durable, the timber must be. It is probable this may be the case in respect of pine timber; but it does not obtain in other equally useful kinds.

The Wych or broad-leaved elm is a native of Britain, and is met with in hedge-rows, or scattered about in forests, like the ash, but without usurping for itself any considerable tracts of country. Some individual trees arrive at an immense size before they become faulty at the core, and, like the ash and oak, live for many years after they are entirely hollow within. Their timber when sound is coarse, and remarkably tough and gnarled; and therefore use- 
3

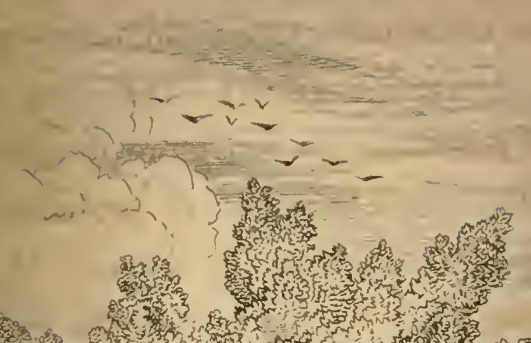

(n)

(n)

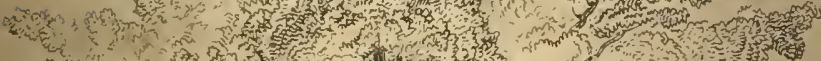
का

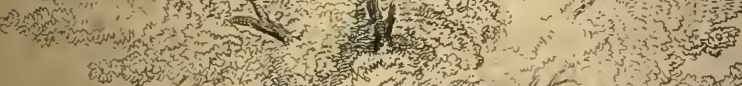

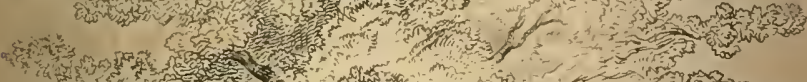

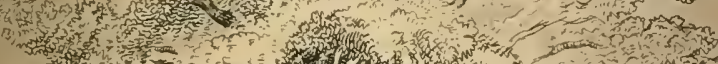
(n)

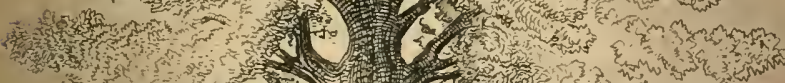

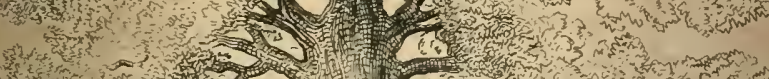
(3)

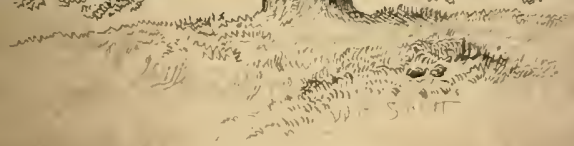



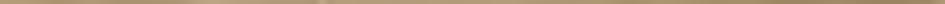
ful to the wheeler, coffin-maker, \&c. but is always considered inferior to what is called the English elm, though this last is an exotic.

It has already been observed that at the time a scarcity of oak timber began to be feh, an impulse was given to the business of planting. Every landholder consideres it a kind of public duty to commence improving and ornamenting his estate by planting. And as prirate interest was closely connected with this public duty, planting forest trees was prosecuted on a most extensive scale.

It appears from an account of the operations carried on in the New Forest under the directions of R. Turner, Esq. Surreyor of that portion of the royal domain, and published in the "Garden- 
er's Magazine," that so far back as the time of William III. and Queen Anne, considerable plantations of oak were made, and which are now (1838) fit for naval purposes, many of the trees containing two loads, that is, one hundred cubic feet each; thus showing that an oak tree on suitable land arrives at a useful size in about a century. "From that time," continues the account, "down to about the end of the last century, but little was done to improve the forest; and as there is scarcely any undergrowth in the open ground, very few young trees are to be seen growing up spontaneously."

During the last twenty years, it seems, several thousand acres have been inclosed expressly for the purpose of 
raising oaks, and it is only to be wondered at that under the apprehension of a scarcity of oak timber, many more thousand acres have not been planted. But it must be considered that according to the above-mentioned account, the commissioners have the privilege of inclosing six thousand acres only at any one time out of the sixty-six thousand acres contained in the forest; that the officers are called on to supply five hundred loads per annum of oak timber to the royal dockyards, and two hundred loads for other purposes. And besides, the owners of adjacent estates have customary or prescriptive claims for beech wood, for fuel, to a very large amount. All which circumstances show that the Commissioners have 
not such mlimited powers as have been attributed to them.

During the same period alluder to in the account, much planting has been done on private estates; to these forestess have been appointed, and the business of arboriculture has becone much. more than ever a distinct branch of rural employment.

On a subject so interesting to the landholder, and at the same time so fashionable with everyborly who had a rood of land to spare, it is no wonder. many books were written and published on the business. These books detailed the various practice of their authors, and embodierl a great mass of excellent information. 


\title{
CHAPTER II.
}

\author{
ON PLANTING.
}

Different methods of planting were recommended and pursued; and these methods were more or less expensirely executed, according to the nature and quality of the soil, and in many cases to the greater or smaller extent of the surface to be planted.

When a naked hill or moor of, perhaps, several huudred acres, was to be 
planted with any kind of tree which harl a chance of succeeding on a thin staple of only a few inches, small two or threeyear old plants of Scotch fir or larch were chosen. These were inserted by a one-handed tool called a planter, formed somewhat like a cooper's adze, invented and first used by the intelligent Mr. Pontey. One or two blows of the planter raised up a triangular piece of the surface, under which the root of the plant was placed, and the raised sod turned back and trodden down with the foot. In this simple, cheap, and expeditious way of planting, many thousand acres of poor hilly land in the north of Scotland and other places were planted about sixty years ago; and though many of the plants perished from the drought of the following summers, as 
many have succeeded as now cover those almost barren hills with thriving trees.

When the surface was too hard or rugged for the action of the planter, trees of a larger size were put in by a mode called pitting. In the execution of this methor, a gang of four men usually worked together; one clears and breaks up the place for a pit of the requisitesize with a mattock; another opens it with a spade; a third carries the plants, and supports one in each hole, while the fourth shorels in the broken earth, and with the assistance of the feet of his companion, fixes the tree upright in its place. This manner of planting is expeditiously performed when the ground works kindly; but if wet or clayey, it is necessary to open all the holes in the 
first place, learing the heap of remored soil to dry or be reduced by frost previous to planting. When the surface to be planted is covered with heath or rank bent-grass, much more labour is required to reduce the soil to a proper state of fineness for the reception of the plants.

When an arable field is to be planted, it receives a previous summer fallow, ploughed as deeply as possible, and cleared of all sorts of weeds. The trees are best planted in October or Novenber'; but if underwood as well as trees be intended to occupy the ground, or to form a cover for game, the last ploughing may be cleferred till about the end of January; and, if the ground be pretty mellow and dry, immediately sown with a mixture of seeds broadcast and har- 
rowed in; after which, trees may be planted at the desired distances. The seeds of oak, ash, beech, firs, larch, and sereral others, may all be sown together, among which if a sprinkling of furze be added it will be no detriment. Spanish chestnuts are dibbed in, as such large seeds cannot be covered by harrows; and in laying down underwood this tree should always be preferred.

This method of laying down land into wood, if carefully performed, is always successful; as there is not only a full number and choice of trees for timber established, but the field answers the purpose of a nursery for many years, and whence may be drawn unlimited numbers of young trees for planting elsewhere. Indeed, where planting is prosecuted on an extensive scale, a nurC 5 
sery or nurseries should be previously formed on the best and most central spots of the land to be planted.

Trees are social beings, always thriving best in the company of each other; even a couple will prosper better, that is, acquire greater magnitude, than if standing singly. Aggregately they shelter each other; and each endeavours to surmount its neighbour. On this account young woods should always be planted thickly; and in order that the deciduous sorts may have a necessary and prompting shelter, evergreen hardy kinds are regularly intermixed. This intermixture is found so effectual in raising plantations of young oak in the royal forests, that it is never omitted. Indeed this is an efiect which must be perfectly obvious to every one in the 
least acquainted with the growth of trees. Notwithstanding the hardihood of the native oak, it requires both warmth and shelter in its youth; and nothing can expedite the growth of this or any other deciduous tree more than planting them between ranks of Scotch pines. So defended from strong and chilling winds, they are drawn up into erect and fine forms; and if, in the after management, the encroaching tendencies of the nurse trees be constantly subdued by pruning and thinning, the principals will go forward prosperously, especially if a little pruning be bestowerl to prevent any of them becoming stagheaded.

It is said that little or no pruning is practised in the New Forest, the trees being, when properly planted on good 
ground left thick enongh to prune each other for a certain number of years. This may be so far economical, as the pruner's wages and time are sared; but neither the soundness nor diametric bulk of the trees individually is promoted by such neglect. A large portion of such trees will certainly be found sound and clear-grained sticks, at the end of four or five-score years; but this is only trusting to the same chance which we meet in every wild forest. Superior trees will there be found, but they are only superior by accident.

All authors, and erery experienced man, agree that deep trenching (and draining if necessary) is the best preparation for securing the most certain success in planting forest trees; and erery wise and spirited planter will arail himself of these means wherever 
practicable. Trenching facilitates the act of putting in the trees as it always should be done; gires scope to the roots, and admits all atmospheric influences so necessary for their well-being. And, moreorer, trenching deeply permits the ascent of those warm vapours which are erer rising from the depths of the earth.

Seeds may also be sown on a trenched surface to secure the birth of seedling plants; and when ornamental plantations are wished to be enriched by a base of holly; hawthom, \&c., their seeds should be sown when the trees are planted.

It is hardly possible to bestow too much care in planting trees intended for profit; the more effectually the land is drained, trenched, and pulverized, the better chance they will have to take to 
the new place, and progress without a pause. Some planters advise the groum to be richly manured and trenched in, to form a rich pasture for the roots, and insist that this proceeding, however expensive at first, is in the end the most economical, in consequence of the trees becoming so much sooner marketable. This method is all rery well in planting a small spot, or for ornamental clumps or groups for embellishing a palace or country residence to produce immediate effect, for which purpose every kind of excitement should be afforded; but such expensive proceedings cannot answer the purpose of a proprietor who merely plants his inferior land for profit. On every private estate there are portions of the surface which, either fron natural poverty or precipitous declination, are unfit for aration or other pur- 
pose of husbandry; such portions are best appropriated to the growth of wood, and from such land the largest profits obtainable will certainly be in the shape of timber and coppice.

The method of raising and planting young forest trees is now so well understood by every forester, and by every labourer employed by them, that it is unnecessary to occupy our pages with any very lengthened account of the processes. Suffice it to observe, that where a public nurseryman is not applied to, or commissioned to furnish the required numbers and kinds of trees, the forester must form a nursery for his own purposes. The area shonld be in proportion to the intended extent of the ground to be planterl: the soil should be a light fresh loam, properly trenched and laid 
into seed-beds and compartments, for the reception of seeds or seedling plants. February and March are the best seasons for stocking a nursery with seeds, or, which is a cheaper plan, with seedling plants of different ages. All the different species of pines and firs, particularly pinaster and Scotch pine for nurses, together with seeds of oak, ash, wych elm, maple, horse and sweet chestunts, \&c., may be sowed in these months, and transplanted into beds in the following spring. All the pine tribe require to be transplanted erery year in the mursery before they are planted ont for good. Indeerl, all trees raised in a uursery should be frequently transplanted, in order to induce a numerous fringe of roots, which renders the final remoral much more safe. The 
preservation of the tap-root, as has been already hinted, deserves not a thought; for every tree, in the course of its progress to maturity, receires much more assistance from its lateral than from its downright roots; and therefore the more numerous the former are, the better chance the tree has to succeed whenerer it may be transplanted.

Oaks are transplanted finally with the best success when they are about five or six years' growth from the acoru. If smaller, they are subject to be choked by herbage if any springs up; and if much older, they are apt to niake a long pause before they start into growth. All similar trees may be safely transplanted about the same age or size: though in the case of some kinds they may be lone sooner or later, according to the state or character of the roots. Some 
roots are naturally extremely subdivided and fibrous; others have but few divisions and fibres: the latter are removed with difficulty, and therefore require frequent remorals while in the nursery; the former bear renoval without injury, even when from ten to fifteen years from the seerl, graft, or layer, and when ten or twelve feet high. But healthy trees of a moderate size and age should always be chosen, and if possible from a nursery of richer soil than that to which they are to be transferred. This is an anomaly in the history of plants, and is decidedly different from what takes place among brute animals. If an individual of the latter be removed from a poor to a rich pasture, a visible change takes place in a very short time, by an increase of bulk and condition; but if a tree be 
starved and stunted in a poor nursery, and is then transplanted into more rich and generous soil, or into one equally poor with that where it was bred, it never becomes so healthy and large a tree as if it had been well nursed in its youth, and had had then a robust habit imposed upon its infant organisation.

The most suitable distances at which forest trees should be planted at first, is four feet; and if the principals and nurses occupy alternate ranks, the whole will rise, if soil and seasons be favourable, with great rapidity. The pines give the requisite shelter, and moreover prompt the deciduous sorts to acquire perpendicular height. Such a plantation soon, that is, in three or four years, becomes a perfect thicket, and where the thinner and pruner must be annually employer!, 
-first, in keeping back the nurses from pressing injuriously upon the principals, and divesting the latter of irregular branches. In another year a part of the nurses will require to be cut out; as well as some of the underling oaks or other kinds. Year after year, the business of thiming and pruning is continued, until all supernumeraries, both principals and secondaries, are cut out; learing a full stock of the former to come to perfection.

It is in this way that the most raluable woods are planted and reared by the labour of the forester. But it is said by some planters, Why take so much pains and be at so much expense in rearing woods, when it may be done with half the trouble? These cheaper methods have alreacly been noticed; but surely 
there can be no comparison between the results? the one is always sure to succeed, while the other nerer succeeds so perfectly, and rery often entirely fails. "Penny wise, and pound foolish," is an old proverb, and never applied with more propriety than it may too often be to some feats of planting. For many instances might be mentioned of attempts at planting forest trees, which have occupied very fair land for scores of years, and which haring made littie or no progress, stand shivering in the breeze, upbraiding the ignorance or parsimony of the proprietor, to whom they can never yield either profit or pleasure.

But planting trees, eren in the most careless manner, is better than doing no planting at all; because if only one in a score succeeds, the labour will be repaid, 
and a valuable feature in the landscape created.

The least expensive mode of raising oak trees for posterity, is that which was adopted by a gallant British Admiral (Collingwood) when residing at his house in the country. He used to have a sack of acorns in his store-room, and on every occasion of his walking or riding in the fields, took with him a pocket-full, which he strewed in the hedges, or among bushes, in any corner where they might have the least chance to germinate and spring up. This was an act the result of which was far away in futurity, yet it was a striking mark of his love of country, and of that service of which he was so bright an ornament.

It is surprising, indeed, what import- 
ant effects often follow the slightest accidental causes. A foreign ship wrecked on our coast has been the means of clisseminating exotic plants unknown to us before; and a single sycamore tree planted in a country where it was a stranger, has in the course of fifty years seen its progeny springing up in every hedge orer a whole parish. The same may have happened with the oak, the ash, or other tree equally productive of seeds.

This being a natural consequence from the mere distribution of seerls, it is a wonder, and even a kind of disgrace to the government of a rich and flourishing nation, to see such extensive tracts of waste land lying useless, in almost every parish in the kingdom; especially when there are so many unemployed 
labourers who might be profitably engaged upon those wastes, in providing and founding an endowment for themselves and all the national poor, now so heavy a charge upon the community.

The grand bar to the execution of any such project is the want of funds. Neither the Chancellor of the Exchequer, the rich capitalist, nor parish authorities, can be persuaded to undertake any measure which will not yield an inmediate and certain profit. Riskirig or laying ont capital entirely for the good of posterity has no allurements for present possessors ; although it is reasonable and capable of the plainest proof that a general measure of this kind would in a course of years provide a fund for the maintenance of indigent poor in all 


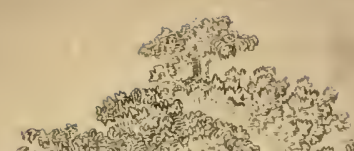

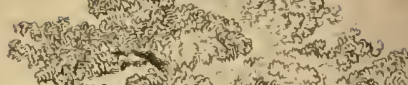

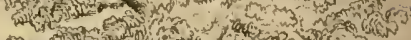

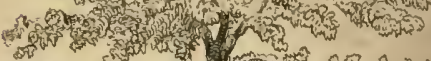
कo a bon (2)

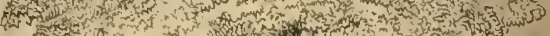

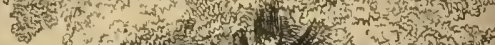

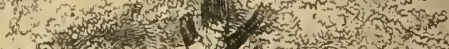

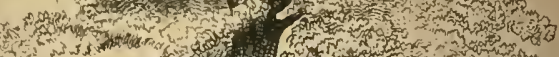
201 to

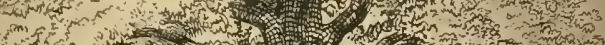

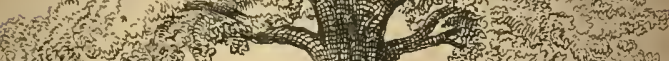

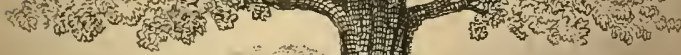

$$
\text { r. }
$$

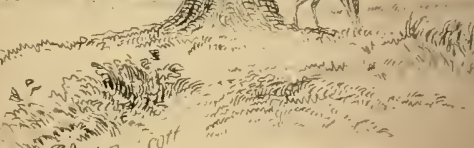




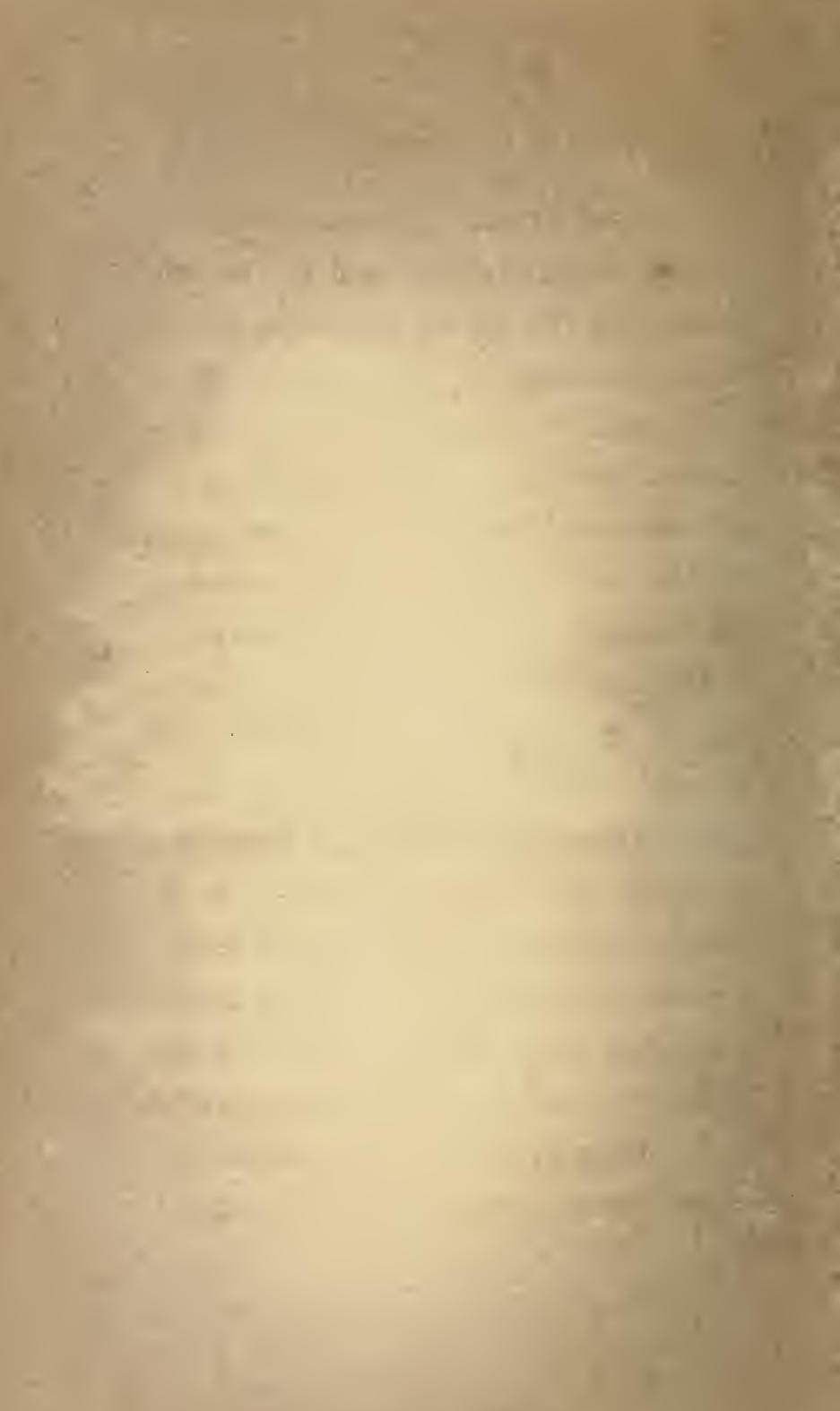


future time. Such a measure would be a grand national object, and nowise unworthy of the wisest statesman, or of the greatest empire.

Manorial rights, entails, and copyholder's privileges, or freeholder's rights of commons, have hitherto been obstacles in the way of appropriating wastes either to the service of the poor, or for contributing towards the exigencies of the state. Parish farms have been tried as a means of employment and for reducing parochial expenses; these in most instances hare failed, merely because no description of arable farming has been profitable for many years last past; and besides, a single farm is too limited a portion of the waste to be of any great avail. But were the wastes gradually and judiciously planted 
with timber trees and coppice, a full provision would in time be created as would certainly operate as a great relief to the future race of rate-payers, as well as furnish winter employment for many of the local poor.

Meteorologists object to the too general clothing the face of the country with wood, lest it should render the climate too moist. This idea is not altogether chimerical. Many countries, as North America for instance, have been rendered much drier and more salubrious since the land has been disforested than they were originally; some of their rivers are even dried up; and it is a consequence which has been observed in other parts of the world. But there is no cause of fear that this arable Is- 
land will ever be so corered with trees as to produce the contrary effect of that which has been experienced in America. 


\section{CHAPTER III.}

ON THE DEFECTS AND NECESSITY OF PRUNING.

The business of raising and nursing young trees,- - the best methods of preparing the ground for their reception when fit to transplant-manner of transplanting - the soils most suitable for each species-together with staking and fencing - are all thoroughly and universally understood. But the only part of the 
woodman's duty which does not appear. to be well defined, or at least not generally agreed upon by practical men, is relative to the necessity of carefully pruning and managing the trees during the first fifteen or twenty years of their growth.

On this very material branch of management many different opinions are held, as well as to the season in which it should be performed, as to the manner in which it should be executed. Some persons imagine that pruning at any stage of the growth is altogether unnecessary, while others maintain the contrary; though the latter have omitted to lay down any practical rules for performing the work except only as regards some of the regular-growing species of the coniferæ;-some foresters adrising 
all the tiers of branches to be constantly, that is, annually cut off, except three or four at the top; while others advise no branch to be dissevered until it is dead, lest the tree should bleed to death.

At the time when very great complaint was made of the great quantities of defective oak timber which was constantly received and rejected in the royal and merchant's dockyards of this country, an urgent inquiry was instituted to discover the probable cause. That this complaint became louder at one time, say about fifty years ago, than it had been previously, may be accounted for by the circumstance of the purreyors having had before that period a greater choice of trees to mark for purchase, and always choosing the soundest-looking sticks they could select, left at last 
full-grown trees, but of inferior character. At this time too there arose an increased demand-greater indeed than could be supplied from either public or private sources, and a scarcity, alrearly alluded to in a former page, was apprehended. Under these circumstances, the purveyors were compelled to have recourse to those trees which they had before refused to buy; and as the price continued to get higher and higher, everything in the shape of an oak tree was eagerly purchased.

In this state of the trade much inferior timber found its way into the dockyards, causing the above-mentioned complaints and inquiries about the cause.

Some persons were of opinion that the defective timber was owing to the 
want of pruning, as ton many of the lower branches were allowed to grow, which very much distorted the grain of the stem, and if any of these branches chanced to die, they in time dropped off, leaving a hollow and rotten scar, which admitted rain and gradually extended the rottenness to the heart of the trunk.

This idea induced many proprietors to become pruners who had done nothing of the kind before; but, fearing to injure the butt, by applying the saw too closely, they cut off the branches at the distance of two or three feet therefrom. This was called snagy-pruning, and was done with the view of preserving the soundness of the trunk; for whether the snaggs lived or died, the butt itself would still remain sound. In this expectation the inventors soon 
found their mistake; many of those unsightly stumps died back, and actually increased the injury to the butt which the pruner had laboured to avert.

The snaggs which had living spray upon them, or produced shoots after they were amputated, continued to live; but whether dead or alive when the tree was felled, their presence still indicated either distortion or dead knots in the body of the tree, and therefore that it was almost useless for planking. [1.]

An improved mode of snagg-pruning has been practised-first, by $\mathrm{Mr}$. Billington in the Forest of Dean, for the purpose of keeping his nurse-trees from spreading injuriously over the better kinds, and by Mr. Blaikie, late landsteward at Holkham in Norfolk, called foreshortening. The object of the latter

D 5 
experienced forester was to prevent the lower branches of hedge-row trees spreading too far over the crops in their shade, and thereby damaging the tenants on his employer's large estate. The lower branches are cut back, but always reserving two or three secondary branchlets on their base, thus keeping the latter alive without risk of their rotting back to injure the butt. [2.]

Other foresters, seeing that a clear and handsome trunk was not obtained by snagg-pruning or foreshortening, concluded that to procure long and straight boles, all the lower branches, of whatever age, should be cut off close to the trunk; they knowing that the wounds, however large, would be in time covered over with new wood and bark, the whole tree would be improved in ap- 
pearance and much more attractive to the eye of a buyer. While prosecuting this plan of pruning,-and in some woods it was done extensively and at a great expense,- the projector forgot that the new wood and bark which covers the scar can never unite with its face so as to produce perfect soundness; and that certainly, when the trees so operated upon came to the sawpit, a defect would be visible at every place whence a branch of any large size had been cut. Experience has proved this fact; and dealers are alive to the circumstance, always cautious of buying out of woods which have been close-pruned, however handsome the butts may appear.

This is an instance that the pruning of forest trees is not yet well understood or practised; and the consequence is, 
that much timber is deteriorated for want of pruning, and great numbers of trees which are healthy are much inpaired in quality by the injudicious manner in which it has been performed.

In order to have a right understanding how far trees are tractable beings, and how far they are under the control of the forester, we must observe what takes place in nature and be guided in our management of them accordingly.

In natural woods we see that where the trees grow up close together, they are individually very tall and branchless, except a few at the top. When such trees are converted to use, they are found of a clear and uniform grain from top to bottom, having few knots, and these only near the pith and very small. But 
trees which grow so near together never attain any considerable diametric bulk; and besides being so crowded, their amount of solid timber collectively is much less than if they had stood farther apart; so that numbers on any given spot never can compensate for the loss of bulk of marketable timber.

On the other hand, where we find trees standing at wide distances apart, (having overpowered and crushed down all competitors around then,) they assume their natural form, and bear widespreading branches, with trunks of corresponding size; containing, together with those of the branches, a vast body of solid timber. This full form and amplitude of the trees is owing to their enjoying full light and air on every side; and this amplitude of a single tree is gained 
in as short a time as would have been required to draw the same up as a slender stripling in the midst of thirty or forty others occupying the same space.

When, however, such trees come to be felled and cut up for use, none but very short lengths of clear-grained timber can be found on the whole trunk; - the bases of every branch cross the longitudinal texture or grain of the wood, and although all these knots may be perfectly sound, such gnarled timber can be applied but to few useful purposes, and, consequently, is always deemed inferior.

Much has been said and written on the value and necessity of growing compass or knee timber for ship-building; and at one time it was deemed impossible to 
build a ship without crooked scantling. But since iron knees liave come into use, and the art of bending timbers into any shape has been practised, natural-grown knees are less in request. Besides, the reports from the dockyards advise every planter to grow clear-grained timber; of crooked stuff they have always more than is wanted.

From the foregoing cbservations concerning the manner of growth of closely and widely standing trees, and of the difference in quality of their timber respectively, it naturally occurs, or must occur to every forester, how desirable it would be to unite the fine quality of the one with the robust or rapid growth of the other.

That such a union of quality with bulk is fairly within the bounds of prac- 
ticability cannot be denied; because there are specimens of forest trees in many different places which exhibit every property that can be desired in trees, whether we consider their value or their beauty. Of these specimens the Woburn beech,* figured and described by $\mathrm{Mr}$. Pontey, may be instanced; and several of the like character, though not so clear in the bole, grow at Shardeloes, the estate of T. T. Drake, Esq., near Amersham in Buckinghamshire. Such fine

* This celebrated tree was a farourite of the grandfather of the present Duke of Bedford. It was, when M. Pontey took a sketch of it, aboint eighty feet in height. The trunk was perfectly round and straight, and measured, from the ground to the base of the branches, exactly fifty feet. The solid contents are not given; but it excels in stately beauty, and if still sound is of great ralue. 
trees, it is evident, have grown up in the company of others, but, from their port or superiority, have become, as M. Pontey says, "favourites," and have always been spared when a fall was made. This growing up surrounded by others soon divested them of their lower branches and gave them length of bole, and being gradually left alone, allowed them to maintain their superiority as well in bulk of stem as in height.

From this account it would appear that to form fine ornamental groves or most valuable woods, the trees should be planted thickly, and when they have attained a sufficient length of bole, thinned gradually till each individual tree enjoys a sufficient share of air and light to bring it to its utmost magnitude and perfection. 
In order that such gradual thinning should be executed regularly, a very ingenious plan has been suggested by a Mr. Laurence, and published in "The Gardener's Magazine." This is performed by first planting the trees in right lines and at equal distances every way. After growing up together till their branches meet, half of the whole plantation is removed; and when those which are left again interfere injuriously with each other, another moiety are felled; and this plan of regular thinning is repeated until the reserved number stand at proper distances. There can be no doubt but that this methodical way of thinning is judicious, in as far as there is no discretion or perhaps erroneous judgment to be exercised by the woodman, and therefore the trees 
are always left at equal distances, which is beneficial to the whole. And if, during this thinning, the principals were kept divested of irregular ramifications of their boles, a very uniform and fine grove of trees would ultimately be the result.

But it must not be forgotten, that in planting too closely at first, the whole plantation is checked: that is, though the trees acquire length, they do not gain bulk of bole in proportion, and time is lost by the growth being retarded from a want of air and light. A tree standing singly, and which has all the benefit of those atmospheric influences, progresses much more luxuriantly than if pent up among others; and if its growth and form be regulated by the pruner during the first fifteen years from the planting, 
the greatest bulk and most valuable quality of timber may conjointly be produced.

It has been asserted, that no pruning at all is required in order to have good timber; indeed, a book has been published expressly to make this declaration! But the author has failed in his proofs: for it is a well-ascertained fact that clear-grained timber cannot be grown unless the tree has had some kind of pruning, either by art or accident.

Accidental pruning is performed by browsing animals, as is so frequently seen in parks and forests. There the trees have usually short butts, and large branchy heads. Or, trees may be made to prune each other by allowing them to grow for many years very close together. 
In the latter case, as has already been observed, the lower boughs quickly perish and drop off by being deprived of air and light. It is doubtless in this way that the fine spars, ladder and scaffold poles imported from the north of Europe and America are grown. The clearness of their grain and freeness from knots show decidedly that they must have grown in very close order. Even in this country, larch, spruce-firs, and other kinds, if allowed to run up closely together, will rise to the height of sixty or serenty feet before they are eight inches diameter at the base, and this where the soil is suitable, in a less period than forty years.

If it be found then that timber of the finest quality is produced by accident, surely the same result may be accom- 
plished by a little labour and the application of skill. And when it is understood how a tree is increased in diameter, and also how. the annual additions of alburnum may be distorted by lateral branches remaining too long where they do harm rather than good, the necessity of timely pruning will be perfectly evident.

As the oak is the most important and most valuable of our forest trees in a national point of view (though owing to its slow growth it is by no means the most profitable), it may be chosen as the object of the following descriptions; and for the sake of better illustration, outlines may first be given of the general forms of the oak as it is met with in a perfectly wild or uncultivated state; secondly, as it is seen in parks or in un- 
inclosed forests ; and lastly, as it may be trained for the purposes of the ship and house builder.

A single oak grown where it has only bushes to contend with, and where no cattle can approach to crop its lower boughs, assumes the form of a vast bush rather than that of a stately tree; its branches stretch out on every side, robbing the central leader, which from its station and erect direction naturally aspires, and by dividing the current of the sap into many channels, checks the upright tendencies of the main stem; the branches become powerful rivals, and maintain a kind of equality as long as the tree lives; and though the solid contents of the whole may be more than equal to what a single stem would contain, yet the 
timber, being so much divided, cannot be converted to any useful purpose with such arlvantage as if connected in one straight trunk. [3.]

Although it is but seldom we see trees exactly of this character, unless on precipitate slopes in unfrequented dells where neither men nor cattle range, yet the sketch is true to nature. It is a form which arises from the constitutional powers of the oak and all other similarly organised trees. That the individuals forming a grove or a wood are each furnished with one or more upright trunks, is rather a consequence of their proximity to each other, than from any inherent property by which the central shoots have a greater ascending tendency than the laterals which are equally exposed to the air and light, 


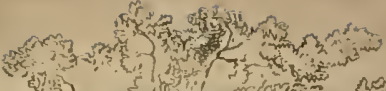
sem $r$ thes

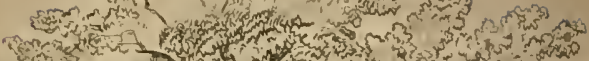
(4)

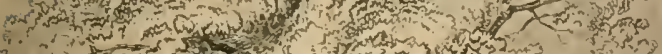

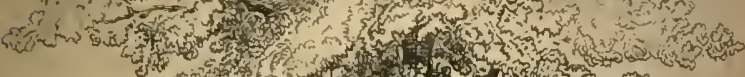

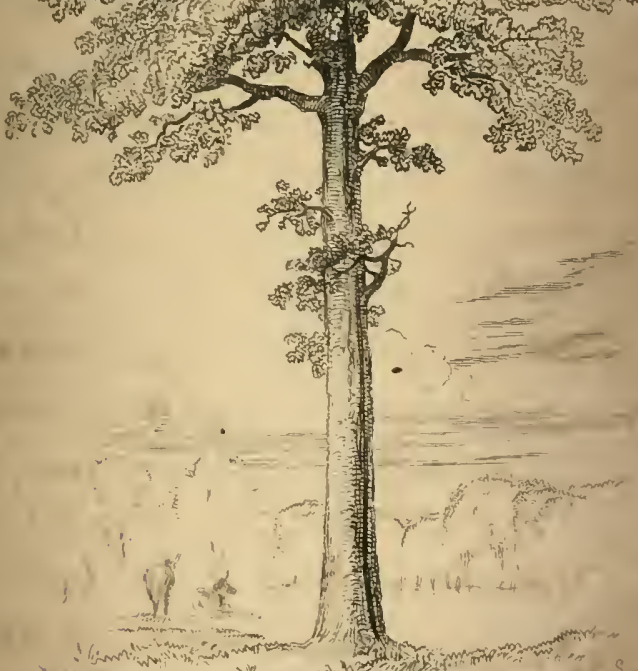

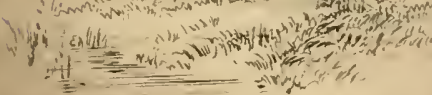



save only from their station, and as recipients of the direct and rertical flow of the sap. This adrantage, however, the central shoots only enjoy during the first stage of their life; because the central shoots which ultimately form the top of the tree are the first to decay, while the lower branches remain long after rerdant and rigorous.

If the same tree stood on a common or in a park, it would take the second form, because its first and lower branches would be constantly foreshortened by the browsing of sheep and other cattle, and could only gain lateral extension after they were above their reach. Thus, a stout butt of clear-grained timber more or less in length would be formed, and bearing a fine head of branches. Sce plate IV. [4.] 
Let us suppose, again, that a similar tree is put under the care of a forester, who resolves by regulating the growth to train it into the finest and most valuable form, securing an erect and straight butt, divested of every branch which by possibility conld deteriorate the quality of the timber, and without checking the growth by extreme mutilation (for in his proceedings both these circumstances must be considered). $\mathrm{He}$ would by an annual examination see whether the leading shoot maintained a due superiority, and that no competitor threatened to attract an undue share of the sap. If any such appearer, he would instantly displace or shorten them, so that they might not attain to more than one inch in cliameter. All other side branches of a less size he would leare, as whether 
they lived or died, they would not prove defects in the wood.

If a tree be consiantly kept pruned according to this rule, it would at last present a form resembling the portrait on the opposite plate. [5.]

The months of April and May are the best seasons for pruning forest trees, becanse the wounds made by the removal of such small branches will be nearly healed orer before the end of summer, and of course no very visible knots or defects will remain in the bole when cut up for use.

This method of pruning necessarily imposes on the forester the duty of an annual review, as the branches will consecutively arrive at the size at which it is advised they should be taken off; but the only difficulty will be, when

E 2 
three or four of the laterals arrive at the prescribed size at the same time. In this case, if the rule be observed, the whole of these three or four branches must be remored at once; which would be, perhaps, too severe a dismemberment of the head, and would probably give a check to the whole system and counteract the very purpose of the pruner. But in such cases, the operator should be content to remove only one or two of the number closely, and foreshorten the others, to prevent their swelling to a larger size than it would be judicious either to leare or take off. These foreshortened branches with their spray would continue to act as necessary parts of the head, and at another pruning might be remored entirely when no longer useful to the system.

That it is absolutely necessary to 
maintain a full head of branches to ensure rapid growth, is perfectly obvious. The head is intimately connected with the root, they being the cause of each other's action; whatever mutilation or injury is suffered by one, the other must suffer, or be paralysed in like measure. There are some exceptions to this rule, as the willow, for example; but among the generality of forest trees it always holds good. An idea was formerly entertained, that robbing a tree of its branches tends to enlarge the butt; but this is so palpable an error, that it requires no refutation. The butt is only enlarged by the number of branches it has produced; nor can there possibly be a large butt unless it has or has had also a large head.

This, it may be objected, is an argument against depriving a tree of any of 
its branches; and so it is if mere bulk of the whole system were the sole object in view; but the intention of the pruner is not to obtain magnitude only, but to concentrate a principal part of the growth into a trunk of the finest and most useful quality.

This is the real and sole use of pruning forest trees, and the business can only be executed with propriety and effect when the trees are young. Pruning an aged tree which has arrived at full form and stature can answer no good purpose; for after an irregular branch has acquired a diameter of from four to six inches, it had better be left where it is; because if cut off, the wound will never be thoroughly healed, and will erer remain a flaw in the timber. So that it is as much the aim of the pruner to prevent the growth of living knots 
which distort the grain, as it is to hinder the formation of lead ones, which deteriorate the wood.

That this must be a certain consequence of removing a large branch, will be best understood by considering, first, how all dicotyledonous stems (that is, stems which are enlarged by annual additions on the outside) acquire diametric bulk; and secondly, how the annual layers of new wood are distorted by branches which have acquired a large size before they have died, or have been pruned off at different stages of the tree's life. This will be best explained and made evident by short descriptions of the phenomena of the growth, and by engraved sections of the various members composing the stem of a tree.

If the stem of a seedling oak be cut transversely after the summer growth is 
over, it will be found to consist of three rery distinct members; namely, pith, wood, and bark. The first is central, and is surrounded by a thin tube of wood called the medullary sheath; which last is covered by an outside coat of green bark also very thin. In the second year the pith remains as at first; a new layer of wood is added on the outside of the first or medullary sheath; and a new layer of bark, called the liber, is at the same time added within the first. A similar increase of wood and bark is in the same manner added in the third and in every succeeding year as long as the tree lives; so that the number of concentric layers of wood, counting from the pith to the interior side of the liber, indicates precisely the age of the tree. A new layer of liber is also annu- 
ally added within the first layer; but they are so closely compressed one upon another that they cannot be distinguished separately without maceration and the assistance of the microscope, except the lime tree and some others, of which the layers of liber are easily separable.

It sometimes happens that in the endeavour to ascertain the age of a fallen tree by counting the number of concentric layers of wood from the centre to the circumference, mistakes are unwittingly made from not considering that many trees have two paroxysms of growth in one summer. This incident is so striking, that these double growths are called the spring and midsummer shoots, and are particularly conspicuous on the oak, the horse-chestnut, and several other trees. Those who are conE 5 
versant with the growth and the manner of the annual increase of a butt, can easily distinguish this apparently double summer growth on a cross section, and therefore are not deceived in estimating the age: whereas if a calculator be ignorant of this circumstance, he will estimate the age of the tree at many more years than he really should do.

The pith is composed of soft cellular matter and destitute of fibres, and appears to be only a temporary organ for the conduction of fluids in the first stage of the life, as it is never increased, and after a score or two of years becomes almost invisible. Pith exists in the stem and branches, but is absent in the roots.

The connected layers of fibrous matter between the pith and the bark is the 
axis of the tree, and aggregately form the columnar body of timber. It is composed of bundles of tough woody threads arranged longitudinally, that is, from the bottom to the top of the stem. The woody fibres are embedded in cellular matter, each cell of which is extensible horizontally between the bundles of fibres; together forming the rascular apparatus of the stem through which the sap and air-ressels pass from the root to the topmost branches.

The pith, as already observed, grows less as it advances in age; but both the wood and bark continue to increase in thickness as long as they retain vitality, as has been already described.

How or whence the new layers of wood and liber derive existence and form, is a question which has not 
hitherto been satisfactorily explained. Some have imagined that they are simple dilatations of either the former year's liber or alburnum; but both these ideas have been proved erroneous by actual experiment. Others have contended that the new accretions are formed by accumulations of what they call perfect sap; that is, sap changed from its thin and crude state as it is receired by the roots, into a richer compound or juice, by the vital chemistry of the plant itself. This opinion is generally received as well by practical as by scientific men; but it is only hypothetical, and far from satisfactory; because it is simply impossible that an organised membrane or any the least portion of organised matter can be generated out of a fluid which is purely homogeneous. 
"But" (it is answered by an arlrocate of the "organisability" of the sap)_"But why not? The cambium is not a simple and homogeneous substance:" granted, because it is in fact the incipient new layers of bark and wood in the act of coming to maturity : "and if in the animal system bone always finds bone in the same blood, and muscle always muscle, so in the regetable system bark may always find bark in the same cambium, and wood always wood. The organised and living molecule abstracts from the alimentary mass such particles as are suited to its own derelopment, and always produces its own type." Now this sentence seems to infer that particles of both wood and bark float in the cambium or alimentary mass, and that they are attracted by 
living molecules of congenial nature to complete their derelopment and typical forms. Unfortunately for this obscure representation, the previously existing layers of bark and wood which are said to be attractive of their congenial "particles" receive no addition to their former bulk; the bark and wood of last year are entirely independent of the like members formed in this.

The fact is, the organisation of every member of a tree has rudimental existence and is developed during the season of growth, not by attracting floating atoms or particles, but by absorption of the elementary food of the plant, supplied from the earth and air; not to create new parts, but merely to amplify them.

The above defence of the organisa- 
bility of the sap is very much akin to the notion of a French naturalist, who endeavoured to accomnt for the production of vegetable membrane on the principle of crystallization: but this, like the kindred doctrine of equivocal generation of animals, was soon exploded as untenable.

In all cases of regetable derelopment we can perceive that there is invariably a rudimental basis whence all subsequent increments spring. Cellular, vascular, and fibrous matter which we see come gradually into view, is only a dilatation or extension of previously existing organic matter. It is thus we see roots and stems elongated, divided, and subdivided; and, at the same time, their several components are engrossed and extended. 
These processes continue for longer or shorter periods according to the natural duration of the plant, or to the climate of which it is a native. The growth of annual plants continues only for a few months-biennials for two summers or for parts of two years, and then cease to grow after producing seeds.

Arborescent perennials are seasonal; that is, growing in summer, and dormant or nearly so in winter; each summer's growtl being distinctly marked, both internally and externally, but with this remarkable difference-that whereas the longitudinal structure is continuous, leaving no notable sign between the growths of consecutire summers, (except on regularly-jointed stems, as the bamboo, or regularly-branching stems, 
as the fir,) the lateral growths of two seasons are plainly visible; adhering to each other, but without interjunction of their respective woody fibres - there being no transrerse fibrous structure in dicotyledonous stems.

Notwithstanding the longitudinal unity of the fibrous bundles which compose and constitute the strength, solidity, and durability of the timber of forest trees in general, there are instances of stems which, when young, have not this continuity of longitudinal structureinterruptions being apparent at every joint. The grape-vine is an instance of this peculiarity; but we know not whether this articulation exists in the old perfect wood.

Nothing shows the necessity of pruning firs more decidedly than the defects 
which beams, girders, \&c. made of that timber are subject to. These defects are not caused by any natural articulations in the stem, but from the regularity of their branching, and proximity of the knots, occasioned by the whorls of branches which have remained too long on the bole. For whatever may be the size of the $\log$, its being studded with large knots renders it extremely suspicious for any purpose of horizontal strength or perpendicular bearing.

It is remarkable, that, notwithstanding the tenacity of the woody layers, whiether singly or aggregately, they are but slightly attached to each other. The alburnum formed last year, and that forming in this, appear to be entirely independent, having no other attachment 
than a thin, fragile layer of cellular matter, acting like cement. It is this want of connexion between the layers which has given rise to an idlea that every laver of alburnum as well as of liber has identity before expansion, and that it has even existence in winter, though almost invisible. In this respect the new alburnum would be only like every other nember of the system, which is expanded from a very small colourless rudiment, to its full size, and colour, and consistence.

It is the alburnum which constantly retains the vital principle, whether it be when only existing as a thin body of lymph, its state in winter, or like pulp or cambium in summer, or as perfect alburnous wood in autumn. While thus changing from its thin colourless 
state in winter to its perfect form and woody consistence in autumn, it is that member of the tree whence all new roots, buds, and shoots proceed. It is that living membrane which heals the wounds and increases the diameter of the roots, stem, and branches: but as soon as the summer growth is orer, the newly-formed wood and liber are deserted by the life, and remain ever after incapable of further increase in bulk, or of ejecting roots or exhibiting buds. The next summer's alburnum exists and is formed on the outside of that of the present summer, not by any interjunction of their parts respectively, but by adhesion only. Year after year the same processes take place, and continue as long as the tree stands.

That the recently-formed layers of 
alburnum and liber continue to act as the conducting apparatus of the juices after they are both deserted by the vital principle, is perfectly evident: but in this they are merely passive, not active agents; they having lost all power of swelling from a smaller to a larger dimension-the only true sign of regetable life. The layer of wood which was formed in the third year of the tree's growth is then as large as it is when the tree has been growing for fifty years. These layers rary in breadth; thin when the tree is very young and very old, and thickest when it is in full vigour, or in those seasons in which the tree makes most progress-that is, in warm moist summers. The layers also vary in thickness in the same season: that sicle of the tree on which there is the greatest 
number of branches and roots has always the thickest layers.

The bark is composed chiefly of loose cellular membrane, connected by a tissue of fibres crossing and inosculating together where they intersect, and which, when freed from the perenchymous and cellular matter, resemble fine gauze. The bark is, however, only an excrementitious prorluct of the tree; and as all new growth is formed within its first outside layers, these are destined to be thrown off piecemeal, or rent perpendicularly, or stretched horizontally without fracture. Some barks are thick and corky, others thin and compact; and. whaterer the consistence of the bark may be, it is often seen that the prerlominating qualities of the juices are always much concentrated in the bark. 
The figure on the opposite plate [6] represents a transverse section of a young oak stem as it appears after the summer growth of the tenth year. The annual layers of wood are traced and numbered; and the perfect or heartwood is distinguished from the white or sap-wood by a deeper shading. We have represented the first four layers as mature, or perfect in hardness and durability in the tenth year; six layers remaining white, or sap-wood. We have found in numberless instances that in every oak tree that is felled there is seldom or never less than sir of the outside layers sap-wood, which are usually hewn or slabbed off before the heartwood is put to use.

Besides the concentric layers which are traced on the figure, convergent right 
lines are also marked. These are called medullary rays by pliysiologists, and are supposed to be ducts for transfusing the sap from the bark to the pith. Others have supposed these radiating lines to be tracts of buds: but this is illusory; because they are not simple lines, but perpendicular partitions of cellular matter, and are not divergent, but convergent in direction, originating at the bark, and not at the pith.

The ten layers of bark are represented by the outer black line; they being too thin to be traced by the pencil, or even identified by the naked eye.

Here it may be observed, that the outer side of each annual layer of wood is represented with a ring of dense cellular membrane, and the inner side is more porous and rascular, containing 
6.

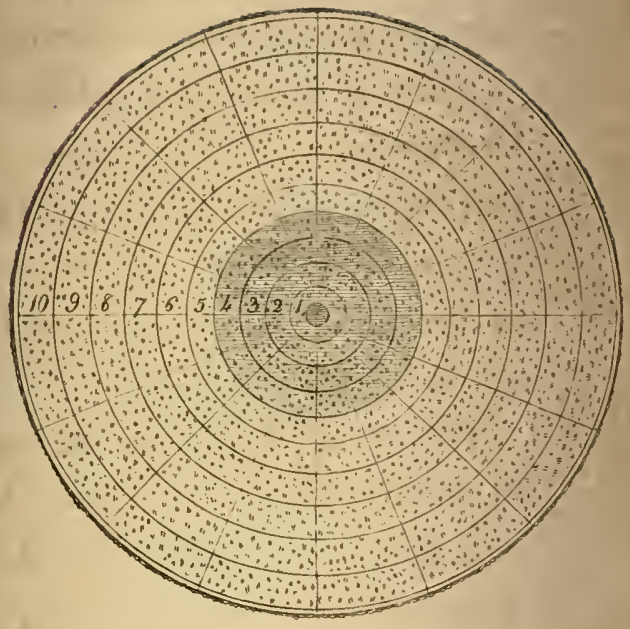




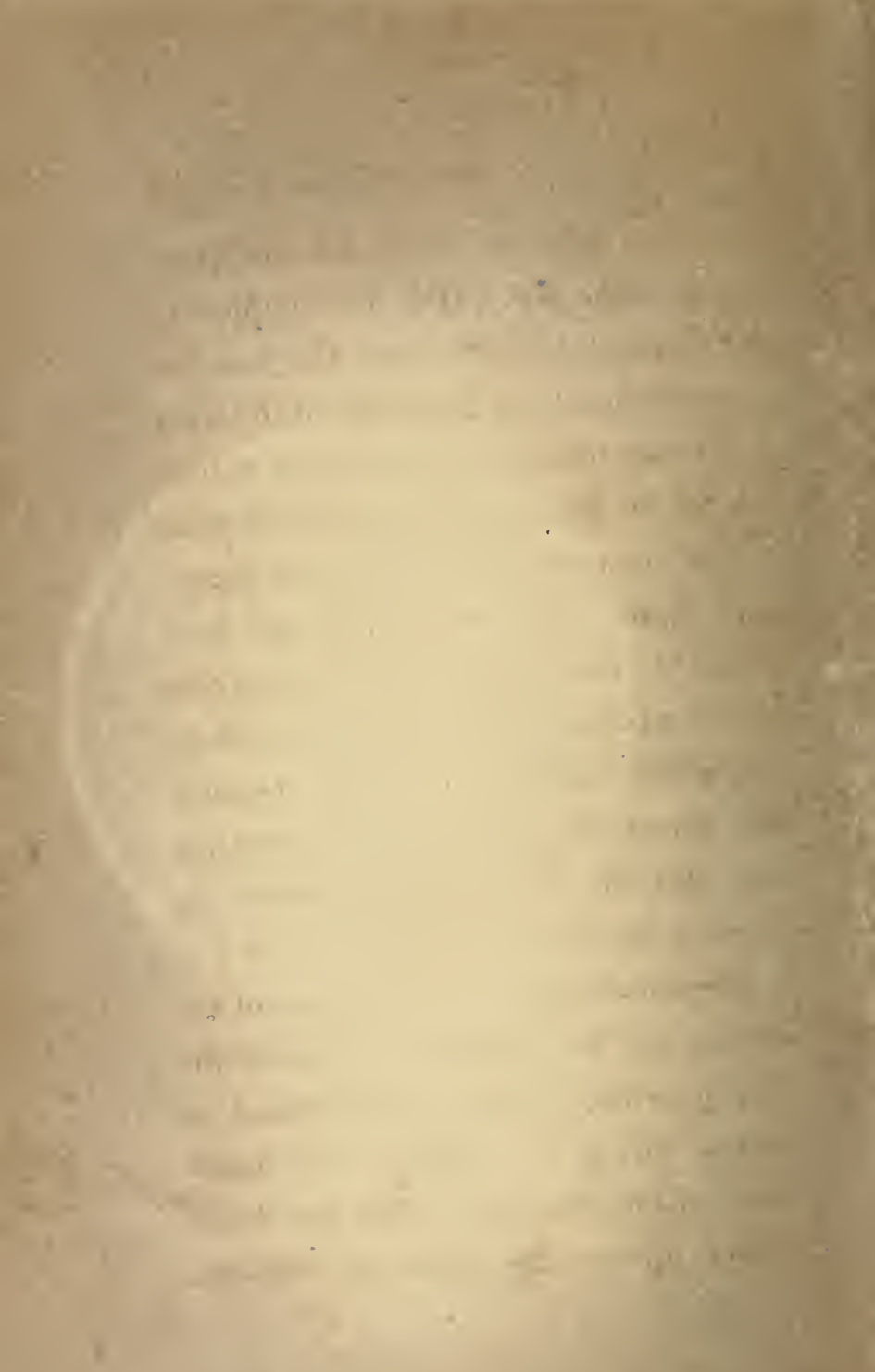

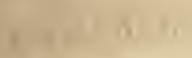

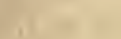

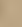

$$
-
$$$$
\text { . }
$$

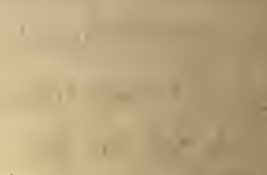

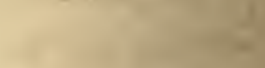

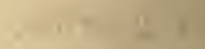

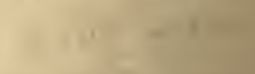
+ 1

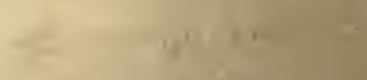


numerous tubes or ducts for the transfusion of the sap. It is the opinion of an eminent botanist, that the vascular constitution of the inner side of the layer acts in the manner or serves as a substitute for the pith to the layer of each year.

The opposite plate shows the imaginary figure of a tree which has been partially pruned; and the accompanying sketch represents a magnified longitudinal section of the same butt, to show the effects of early and late pruning, and also the cross-graining where no pruning has been bestowed. [7.] [8.]

The small defects near the base of the section are the remains of some of the first branches, which were browsed or broken off in the second and fourth years of the tree's life. The two knots higher up are the bases of branches 
pruned closely off about the tenth and fifteenth years. The two next still higher are the remains of two opposite branches which had been cut off after the sixteenth year, at some distance from the butt, one of which died back, and the other continued to survive in consequence of having a branchlet proceeding from it.

Now it is evident from the annexed delineation, that if in the progress of the growth of the butt no brauches had been allowed to remain after they had acquired a diameter of one inch, the butt would have presented an almost uniform and clear-grained body of timber, fit for any purpose of the builder or joiner, cooper or lath-render. The knotty remains of the small spray left on the trunk can do no injury in distorting 
the grain, as they must ever remain at less than an inch in diameter; and being overshaded by the branched head, will imperceptibly disappear.

All the principal branches of a tree originate at the pith; and as they are only divisions of the stem, they are similarly constituted, and are engrossed in the same manner. But secondary branches may be, and often are seen sprouting from the alburnum of aged trees, long after the central pith and axes of wood are rotten and gone.

It is the knowledge of the foregoing descriptions of the growth which directs and sanctions the operations of the pruner in the management of young trees. His especial aim is to obtain the greatest quantity and best quality of timber on the smallest space and in the 
shortest time. And when all the means of judicious planting and proper culture are followed by the necessary pruning, there need be no doubt of success.

The business of thinning and pruning is generally performed at the same time, in order that the poles and loppings may be sorted, numbered, bound, and cleared off together. The supernumeraries are first removed, and the principals are looked orer, and all irregular branches, according to the before-mentioned rule, taken off.

When the pruning cannot be done on foot, a light ladder of about twelve rounds will be required, together with a light keen bill, and two stout turn-saws, one in a common handle, and the other fixed in a stiff pole six or seren feet long. Thus equipped, the pruner will 
be able to form a clear bole of fifteen or sixteen feet high in a few years; and which may be carried higher with longer ladders; but as the business in that case would be attended with both expense and danger, it need seldom be executed.

The securing a clear butt of from fifteen to twenty feet in height is a valuable point gained, and well worth the labour bestowed. Besides, there is a chance that accident may do as much more. 


\section{CHAPTER IV.}

SUITABLE SOILS FOR TREES.

WE cannot help considering it as a wise provision of Nature that trees do not require the richest land. The deep alluvial soils so productive of corn and pasturage are not so well adapted to the growth of trees. These seem to need a more porous surface for the spread of their lateral roots, and in near contact of atmospheric influences, provided they 
have also a substratum of moist clay, or gravel, or chalk, or rock to feed upon. The oak luxuriates on a clay subsoil; the beech on one of chalk : and almost all other forest trees affect a light loam on a gravelly subsoil. Thin moorearthy soil, though from want of depth it is unsuitable for the generality of trees, is not rejected by the Scotch fir, the larch, and several others of that tribe. Bog-earth, or any other very moist soil, is favourable to most of the willows: and deep bog-earth is the natural soil of the alder, and several of the poplars, particularly the white or abele, the aspen, and the black Italian. The first of these arrive at a noble size; containing fire or six loads of timber in the boles, bearing wide-spreading and lofty heads. Unluckily, the timber is inferior, and 
almost always faulty when cut up, owing to thestumps of the fallen branches rotting back into the bole; forming holes which are afterwards inhabited by the nuthatch, the starling, and woodpecker. On very wet useless spots of an estate, where more valuable trees would not succeed, the different species of poplar will soon form a conspicuous feature in a landscape. Some of the American species are highly ornamental, grow rapidly in moist ground, and are well adapted, like their congener the Lombardy, to form screens or sheltering hedges either for buildings or other trees.

Sandy soils are of different qualities, but all may be soon covered with useful trees. The Scotch and stone pines, the pinaster (if rather moist), and the larch, birch, sycamore, and all the other ma- 
ples, will all readily succeed in light sands.

The generality of soils are, however, of a mixed character; and if well drained and trenched, digged, or deeply ploughed, almost any kind of forest tree will succeed thereon, if carefully transplanted at the proper season.

It may be remarked that though some kinds of trees are decidedly aquaticssuch are the alder and some kinds of willows-yet other kinds, which are commonly met with on dry ground, grow much more luxuriantly if planted on the bank of a lake or river. This can only be attributed to their having a more copious supply of moisture in the summer months.

The above, together with the Coniferæ, are the kinds which are commonly F 5 
raised for pleasure or profit in this country. But there are many American trees in our ornamental plantations. Among these may be mentioned the acacia (Robinia pseud-acacia) as highly ornamental in its foliage and flowers, and useful for its extremely hard and durable timber. This tree grows well in any dryish gravelly loam, and should be planted in pretty close order, either by itself or among other kinds. It requires a good deal of attention during the first ten or fifteen years of its growth. It shoots rapidly when young; and the larger shoots being extremely brittle, are liable to be split from the stem by the wind. To prevent this, the side-shoots, and particularly those which rise from the base of the leader in the same summer, should 
be stopped as soon as they are twelve inches in length. This species of pruning will enable the tree to resist the wind until the youthful vigour is over; after which its shoots are no longer liable to be broken.

But few trees of British growth of this kind have yet been offered for sale, very few having arrived at full size since they were first planted in this country. The timber is eagerly sought for by millwrights; the wood being one of the best known for making cogs, wearing well, and as smooth as metal when put to use. This is the locust tree of American builders, and of which it is said, that a rotten gate-post made of locust has never yet been seen.

Of the maple genus we have many sorts from America. They are mostly 
small trees, but ormamental from the great variety of colours of the foliage. Their timber is chiefly used by turners and cabinet-makers. The largest of the genus is the common European sycamore, a free-growing ormamental tree, but producing timber of very inferior quality; and being particularly liable to the worm, it is seldom used in buildings, and only fit for the toy-men.

The lime is another ornamental tree, and, like the horse chestnut, is very proper for park scenery. But neither are British foresters, their timber being of little value, except for the carver, and some very minor purposes.

Of the óak we have many species from America; but none of them are equal in quality to our own naral oak. The Turkey oak is a free-growing and 
FOR TREES.

useful tree, and deserves a place in every plantation. The evergreen oak yields durable timber; but it is a slow grower, and never arrives at very great size. The cork oak is of sinilar cliaracter.

of the beech, there are several varieties: some of them are remarkable for the colour or form of their foliage. One is called the purple; another the coppercoloured: one has cut leares; another is of so dwarfish a liabit, that it only appears, even when full-grown, as a low bush. Indeed, we have now numerous species and varieties of all our hardy trees, as the following particulars show:-

Of the oak the two principal sorts common in British woods are the Quercus robur, supposed to be the old English or naval oak, otherwise called by 
botanists Quercus sessiliflora, or sittingflowered, or stalkless-fruited oak. The other is the Quercus pedunculata, stalkfruited oak, said to be a species, but probably only a variety, as the specific character is not always constant. The habit of the trees is somewhat dissimilar, and may be identified at a distance $b y$ an experienced eye: the branches of the first are more tortuous and abrupt in their outline; while those of the second are more flowing in their spread, and freer in their manner of growth.

Of these there are several acknowledged varieties; such as the Luccombe, which is nearly an evergreen; the variegated-leaved, and the Durmast; which last, however, is considered a distinct species. There are above seventy species of exotic oaks, described chiefly 
as natives of America and the South of Europe, of which we have the following in our ornamental plantations; namely,the Turkey or iron oak, a free-growing and useful tree; the willow-leaved; the white, black, scarlet, and fern-leared species: there are also the Gramuntia, and Catesby's, and several other ornamental sorts obtainable from our public nurseries.

Of the elm, there are six different sorts found hardy enough in Britain. The first is called the Englisin elm; though as it seldom or never ripens seed in this country, it is probably a foreigner, though long naturalized. It is never seen but near or where there have been the habitations of man, and chiefly as arenues or as hedge-row timber; for which latter purpose it is excellently adapted, 
because there is a constant succession of young trees rising from the old roots, provided the old trees have not been propagated by grafting; a common custom in nurseries, suitable enough for avenues, but not for hedge-rows or woods planted for profit, for these should be propagated by layering. We know many hedge-rows of this tree, chiefly near old manor-houses, whence the forefathers of the present owners have drawn immense numbers of full-grown trees without exhausting the stock ever coming forward for the use of the present and future generations. Where once an English elm is established in a favourable situation, it is a difficult matter to get rid of its progeny: on this account the tree is objecterl to in dressed ground, because of its suckers disfiguring the turf. 
The wych, or common broad-leaved native elm, is a large rambling growing tree, yielding coarse but strong useful timber for many out-of-door purposes. Allied to this, botanists have discovered four other sorts; namely, the cork-barked, the smooth, the mountain, and the spreading-flowered; all of which are timber trees, and all are or may be propagated from sced.

There are sereral exotic species which are cultivated and rise to a timber-like bulk; namely, the winged, the pendula, and the white, which are natives of North America ; and there is also what is called the white elm, a native of Hungary. These are usually met with in ornamental plantations. Elms require less pruning than most other forest trees.

Of the common ash, which is by far 
the best of the genus, there are no less than ten varieties, all used as ornamental plants. Of these, one of the most striking is that called the pendulous or weeping ash; though horizontal growing would be a truer description, as its branches are only pendulous by art, that is, by grafting a weeping scion upon a tall stem of the common sort. For assuredly a layer of this variety would spread its branches close to the surface of the ground rather than rise in the air. It is therefore only useful as an ornament.

The only other species said to be natives of England are the various-leaved and warty sorts: both rise to the size of trees; but it is doubtful whether or not they are more than varieties. There are nearly forty other sorts described, mostly 
natives of North America and the South of Europe.

Of the birch we have in cultivation nearly twenty species, only two of which are natives of Britain ; namely, the common white, and the pendulous-branched. Of the first there are three varieties propagated for sale in public nurseries and in the arboretums of curious planters; the second is a much-admired tree in every ornamental plantation.

The only species of alder indigenous to Britain is the A. glutinosa, or clammy alder, an aquatic tree of frequent occurrence. Of this there are five varieties, which differ from the first chiefly in the shape or size of their leaves. Of exotic species and varieties there are sixteen described, the major part of which may be found in public nurseries. 
The genus willow is rery extensive, there being no less than one hundred and sixty-six species already described. Many of them are highly useful plants, and a few are even worth cultivation for their timber. A Lincolnshire proverb declares that "a willow will be worth a horse, before an oak will be worth a saddle." This is an allusion to their rapid growth; for though their timber is light and by no means durable, the quantity produced for shoe-lasts, cuttingboards, a few domestic articles, and even for firewood, compensates the planter. Though the willows are chiefly shrubs, several of them rank as timber trees, particularly the white or Huntingdon species, when planted on rich moist ground, where it becomes a large tree in a very few years. It is not so 
soon liable to rot at the centre as some of the others, and therefore affords boards of good width for many useful purposes. The yellow-branched, the brittle-twigged, and the great roundleaved, rank next to the Huntingdon as trees, and also for coppice. The common osier and several others are cultivated for the basket-makers.

Of the poplar genus we have now a good many rery stately trees, both native and foreign. Of the former we have the abele or white, the snow-white, hoary, aspen, and black; and of the former we have the Athenian and black Italian, both valuable kinds, and well worth the attention of planters. The Lombardy, for its tall conical shape, quick growth, and unrendable quality of its wood, is a unirersal farourite for planting on land na- 
turally moist. Several of the American species attain to a very large size in this country; as the Carolina, the necklacebearing, the large-toothed, the sweetscented, \&c. There are above twenty different species which are hardy enough for our climate, and which serve to diversify our woods, and add to our stock of timber for many useful purposes.

The lime, if not a native, has been naturalized for ages. Four species are said to be found in our woods; namely, the small-leaved, intermediate, common red, and broad-leaved. They are more ornamental than useful timber trees; though their mild, close-grained, light wood is chosen for many purposes-as carving and the like. The flowers are sweet-scented, and their outline being regularly formal, are particularly well 
adapted for beautiful scenery. There are six exotic species in our collections, all of which are hardy.

The horse-chestnut, in its general character as a tree, ranks with the lime. Its timber is inferior; and its value consists in its fine flowers, and majestic port when full grown. There are four species; namely, the smooth-leared, the Ohio, the ruddy, and the pale-flowered: there is also a variety with partycoloured leares. There is a nearly allied genus called Pavia, which has been separated from the horse-chestnuts, on account of their fruit being smooth, instead of prickly like the chestnut. The pavias are smaller trees, but the flowers of some of them are remarkably showy; as red, flesh-coloured, and yellow. 
They, like the chestnuts, are only considered ornamental.

The Spanish, or sweet chestnut, is a valuable timber tree, and one of the best for underwood: it thrives in any gravelly loam. There are fire species of this tree; namely, the common, the black, grey, ash-leaved, and wing-fruited, all trees of considerable stature.

Nearly related to the sweet chestnut is the genus Carya, or hiccory-nut, of which there are ten species, natives of North America. In this country they form elegant trees of middling size, and rery suitable for garden scenery.

In the same natural order with the foregoing nuts, we find the common walnut a valuable timber, as well as a fruit tree. The walnut has naturally a 


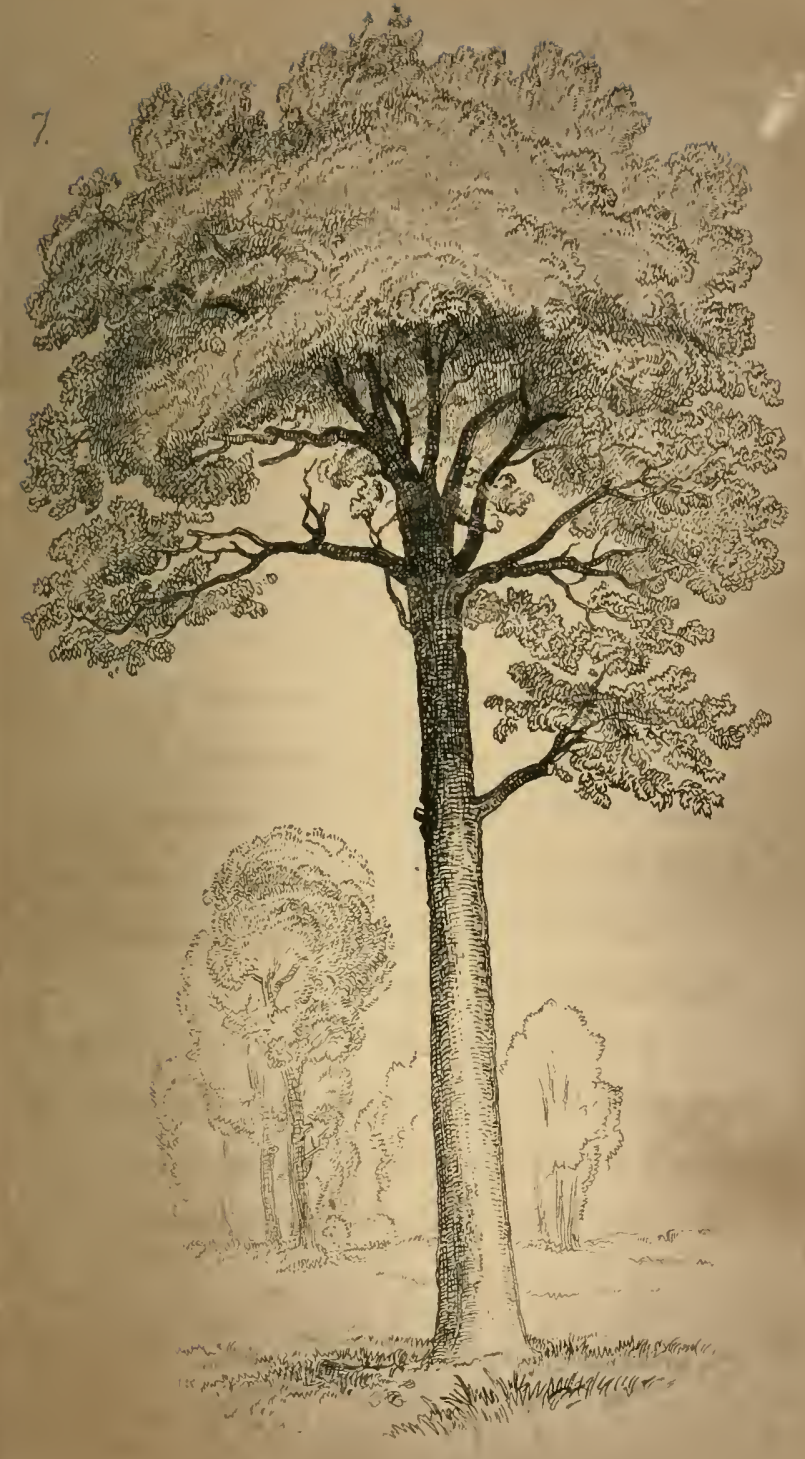


$x^{2}$

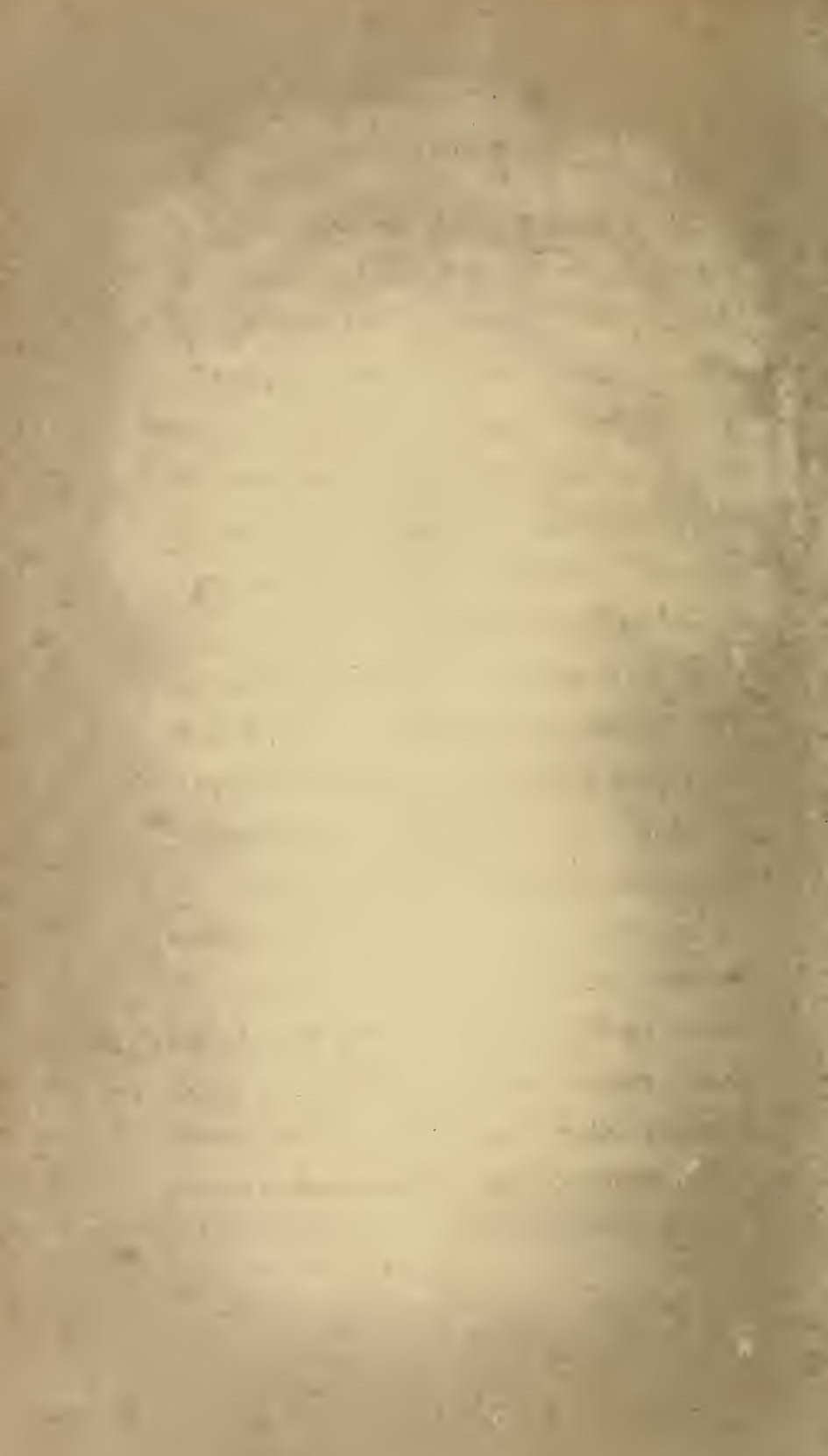


large-spreading head, because it is allowed ample space when planted in orchards; but when placed thickly together among other trees, it rises as quickly and attains as great a height as any other in the forest. Treater as a forest tree solely in consideration of the value of its excellent timber, we have no doubt but that it would turn out as profitably as any other kind whaterer. The walnut affects a dry loamy soil, and, like other trees, requires a little pruning when young, as its lateral shoots are inclined to permanence.

Another fruit tree which furnishes durable timber is the wild cherry. It grows rapidly among others, and attains to a considerable bulk of bole as soon as most other forest trees. The wood is valuable to the cabinet-maker; and 
the heart, if sound, is as durable for gate-posts as the oak itself. It is a tree which should not be rejected by the general planter. Some of the cultivated varieties become immense trees before they fall to decay; the owners being obliged to have fifty-round ladders to gather the fruit.

The platanus of Asia, where it is much regarded for its shade and large size, and the other species from America, hence called the western platanus, are both noble trees, and particularly well adapted for park scenery: but they are not yet ranked as forest trees, their wood being light, and though pretty dense, not so durable as our other more common trees. As, however, they arrive at a large size in a much shorter period than some of our other 
foresters, they deserve notice, as their timber for minor purposes may be equally valuable with those of a more coarse and hardy nature.

One of the most interesting and useful orders of trees is the Coniferæ, or conebearing. This title includes the pines, the firs, larches, cedars, cypresses, arborvitæs, yews, \&c. Of the pines there are above forty described, only one of which is indigenous to Britain, namely, the wood, or Scotch pine, found in original forests in the North of Scotland. Of this tree we have two sorts: one having a rough, longitudinally cracked, persisting bark, with branches rising obliquely upward and aggregately forming a pyramidal head when young; the other having a thinner, smoother bark, successively thrown off in irregu-

$$
\text { G } 2
$$


lar-shaped pieces, with branches less numerous, and stretching out in a nearly horizontal direction, and at last nearly drooping. From this position of the branches they are liable to be split from the bole when loaded with snow or ice in certain states of the weather. Notwithstanding this defect of the form, it is a highly picturesque tree, and moreorer yields the best timber; at least, far superior to that of the other sort, which is much too common in lately-planted woods. This circumstance has attracted the notice of nurserymen, who only now raise seedlings of the better sort.

The other species of pine which have been found to answer best in our plantations, are the pinaster or cluster pine, the stone, the Weymouth, the Cimbra, 
New Jersey, and the Corsican pine or larch. There are above thirty others described, chiefly considered as objects of curiosity rather than useful trees, and therefore only met with in botanical collections.

Of the firs none are natives of Britain, all being found in North America, or on the continent of Europe. Those mostly preferred by the British planter are the silver, the Balm of Gilead, and the different species of spruce firs. Of these last there are four species; namely, the Norway, the white, the red, and the black. The Norway and the white are most prized, because of their rapid and lofty growth. The hemlock spruce arrives at a middling-sized tree in this country, but is a slow grower and only suitable for dressed grounds. There are 
twelve other sorts of firs introduced, but too lately to show what they may ultimately become in the climate of Britain.

Of the larch there are four species; namely, the common white, the Daurian, the black pendulous, and the small coned red. The first is most generally planted, and proves to be one of our most valuable timber trees.

The cedars are mostly ornamental trees; for though that of Lebanon attains to a full size in this country, its timber is of little value to the builder. Several trees of this species were felled off the estate of Moor-park in Hertfordshire, about forty years ago, containing five loads of timber each, and which were purchased by London builders for quartering at no higher a price than they 
gave for the youngest Scotch pines felled in the same park. Another species of this tree has been introduced into this country from Nepaul, called Deodora; and hopes are entertained that it may be naturalized. That beautiful tree, vulgarly called the deciduous cypress, is now a new genus, of which there are two species known as Taxodium disticha and $T$. capensis. The latter is only a shrub; but the former attains to a very large tree.

Of the cypress we have only the common evergreen species, and two varieties: but they do not rank as forest trees, though yielding extremely durable timber.

There are a few inferior foresters, which, though they do not rank as timber trees, deserve to be noticed: one is 
the hornbeam, a middling-sized slowgrowing tree, found wild in many places. 'The trunk, though never large, yields timber of a remarkably tough character, on which account it is useful for many rural purposes, farm implements, \&c.

Of the maple, besides the sycamore, there are two other wild sorts common in this country. 'The wood, both of the roots and stems, is much valued by cabinet-makers. There are numerous species of maple introduced from the South of Europe and North America; but they are only employed as ornamental plants.

The tulip-tree and yellow-flowering Virgilia are two North American olmamental trees; but as they grow 
FOR TREES.

freely in our woods and attain to a timber-like bulk, their wood may be found to be useful for some purposes in this country at present unknown. 


\section{CHAPTER V.}

TREATMENT OF WOUNDED TREES.

Trees are liable to accidents during their growth, by which the soundness of the timber is deteriorated. The branches are shattered by wind; insects destroy the foliage or the bark-sone even devour the pith and solid wood: all which accidents either retard the growth, or injure the timber. When 
a branch is torn off by the wind, a naked wound is the consequence, and the disbarked parts are soon acted on by the weather-decomposition is induced, insects are invited to deposit their eggs in the dead or dying members, and the destruction goes on even into the heart of the tree.

When an accident of this kind happens to a favourite tree, and the wound is not too far from the ground, some topical remedy may be applied:- the ragged edges of the wound may be smoothed, and the naked wound immediately brushed over with a coat of grafting wax, resin or pitch, laid on hot. The use of this or any other application is only to secure the wood from the action of the air, and to disgust the wood-eating insects. Such 
topical remedies, however, can only be practised in few cases; to assist in the preservation of an ornamental tree, for instance; but as a general duty of a forester in extensive woods, the thing is wholly impracticable.

When a branch dies, or is broken off by the wind, the remaining stump or base soon becomes rotten. Certain beetles and flies choose this decaying part to lay their eggs in; these soon become maggots, and attract the green and pied woodpeckers to dig out the larvæ as their natural prey. If the rottenness extends, as it usually does, into the body of the tree, and downward withal, the woodpecker soon perceives this by hammering the bark below the scar with his strong bill; and just before breedingtime, begins to form a round passage 
into the interior, which the bird intends to nestle and breed in. The place of the ailet hole or entrance is chosen with great instinctive skill, as it is invariably just below the protuberance formed round the base of the rotten bough; and this, lest rain should fall or run into the nest. These beautiful birds are wrongfully accused of damaging trees: but it is a false and scandalous charge, as they never wound a sound tree. But as soon as insects have begun their work of destruction, the woodpeckers are promptly in attendance to draw the maggots forth with their long, flexible, barbed tongues.

The pied woodpeckers are called by woodmen jarr-birds, because they occasionally seek their insect prey on the dearl tops of trees: and as the dead wood is thickly perforated with small worm- 
holes, in which various insects lodge, the bird, in order to rouse them from their hiding-places, sits, or rather hangs upon the side of the branch, and with his beak strikes it forcibly and rapidly, producing a jarr which may be heard at the distance of a mile. The alarmed insects sally out only to be clevoured by the cunning disturber. The fact is, these birds are more serviceable than hurtful, and it is a shame to see so many of thëm nailed up at the end of the keeper's lodge, among hawks, polecats, stoats, weazels, and other predacious animals.

High winds cause much damage to trees, not only by breaking off large boughs, but by twisting the boles, and producing what is called wind-shakes. These defects are of two kinds-lon- 
gitudinal rents which extend from the top to the bottom of the butt on one or both sides, and reaching from the pith to, and also through the bark. In the latter case the rent soon becomes visible, either by the oozing of sap, as in the elm, or by the extra swelling of the new alburnum along the opening, and there forming a seam, which remains visible for many years, though the rent in the axis of wood never heals. It is therefore an indication that the tree should be felled. Another windshake is called the cupshake: that is, several of the interior layers of alburnum separate from those in the interior so entirely, that the axis is contained in a series of tubes, and when cut up at the sawpit, they fall to pieces.

These defects, caused by violent winds, happen in consequence of the head of 
branches being unequally balanced; that is, where many more branches grow on one side than there are on the opposite. Such a tree being acted on by lateral gusts of wind, the trunk is twisted repeatedly half-way round, and, of course, disintegration of the longitudinal grain is the consequence.

There are some kinds of forest trees which suffer more from such accidents than others. The elm, if wounded by the roller in parks, or by the wheels of any carriage, or if it loses an arm by decay or by the wind, very seldom heals perfectly. The sap begins to flow from the wound, and is continued at all seasons, and presents a stream of sanious matter reaching from the wound to the ground. Nothing but topical operations, performed in the earliest stage of such 
wounds, can have the least effect. While the gangrene is superficial, it may be cut out by the knife or chisel, and the still healthy parts being anointed with hot pitch or tar, and the cavity filled with grafting clay, may arrest the malady: but after it has assailed the body of wood, there is no available cure. Accidental wounds of the bark are easily cured by keeping them covered with grafting clay till new wood and bark are formed again, which takes place very rapidly provided the wound is carefully and constantly protected against air and light.

Trees are subject to a kind of disease which is denominated "constriction of the bark:" Its effect is keeping the tree in an inactive state, so that it makes no progress in growth; the foliage is dimi- 
nutive, and the shoots short and feeble; and in the case of fruit trees, the crops are scanty and inferior. That forest trees are subject to the like defect, is more than probable: for many stunted specimens are seen in every wood we enter. As the bark, as before mentioned, is an excrementitious part of the plant, Nature intends, that as a new bark and a new layer of wood are every year formed within the outer or first-formed bark, this latter should either be gradually thrown off entirely, as in the platanus, stretched horizontally, as in the beech, or rent lengthwise, as in the oak, to make room for the new growth within. If, however, from any cause, the outer bark becomes unnaturally indurated, so as to lose its power of expansion, the internal growth is confined, and all the functions 
of the tree are checked and paralysed; hence it remains almost stationary, the prey of insects, moss, lichen, \&c., in which state it is said to be hidebound.

The orchardist's remedy is scoring the bark from the top to the bottom of the stem, with the point of a pruning-knife. This, if done about the time the buts begin to burst in the spring, operates as a certain relief, shown by the subsequent swelling of the stem, and an evident renovation of the vigour of the whole system.

This is a manipulation to which forest trees have never, perhaps, been subjected, though long ago recommended by Mr. Pontey; nor have they been deemed worth such manual care. But there can be no doubt that if they suffer from the 
same cause, they may be relieved by the same means. Some practitioners are not content with merely scoring off the bark: they shave off all the dead hardened surface, leaving only two or three of the last layers of liber, which are quite competent to carry on the usual processes of the growth. It is well known that the cork oak is re-invigorated by the periodical removal of its outer layers of bark; and no doubt all other trees which have not a resinous or gummy sap would be assisted by the removal of their dead scabrous covering.

Instances occur in which this remedial practice may be bestowed: young trees of rather large size are sometimes transplanted; these, if they live, (oaks particularly,) remain often for years before they begin to grow away freely, 
and during this pause become covered with parasites. To induce renewed action, no better plan can be tried than scoring and cleaning the bark, as a means of recovery.

It very often happens that trees require the pruning-knife soon after they are transplanted. This becomes necessary from the trees not taking readily to their new place, but remain in a stunted state for a year or two, without making any progress. The best remedy in such cases is to cut them over close to the ground. This will cause the root to throw up one or more strong shoots, and be excited into fresh vigour, yielding such a supply of sap as will cause the shoot or shoots to overtake the other more thrifty trees in a very short time. The removal of a decrepid or languid- 
growing part of a tree prompts a renewal of the vegetative powers, by calling into action new organs which excite each other.

Some species of willow, if allowed to grow up into full stature, gradually lose vigour-become rotten at the core, and shortly fall before the storm; but if repeatedly cut down, live and luxuriate for many years. This fact militates strongly against the doctrine that the leaves are the principal incentives of the growth:- the fact is, they are only auxiliary .

Trees are frequently struck by lightning. It seems that the oak and elm are more attractive of the electric fluid than others, owing perhaps to the solidity of their boles. The former is some- 
times shattered to pieces, the fluid seeming to descend through the rery centre of the axis. On the elm and Scotch fir, the fluid often passes down between the wood and bark, stripping off the latter in long shreds, or rending it open from top to bottom. These partial strokes do not seem to affect the general health of the trees, as they continue to thrive notwithstanding the longitudinal disruption of their bark. Single trees are more liable to be struck than any one surrounded by others. This may be owing to the lightning becoming diffused by numbers in its descent; but a single oak is the most attractive of all others, and the most dangerous to take shelter under in a storm.

Elm and lime trees are liable to be 
damaged and even killed by the larva of the Scolytus destructor, an insect which inserts its eggs into any vitiated part of the bark, and generally near the ground. The larvæ feed on the inner bark and edges of the living membrane, thereby preventing it from spreading over to heal the wound. It is remarkable that the trees no the boulevards of foreign cities, and those on malls and public walks or arenues in this country, suffer more from those insects than trees in the country, or in extensive woods. This may be accounted for, by stating that trees in public walks are more liable to be damaged in the bark than those in the country; and while the woodpeckers have free access to the latter, they are constantly scared away from the former. 
\%.

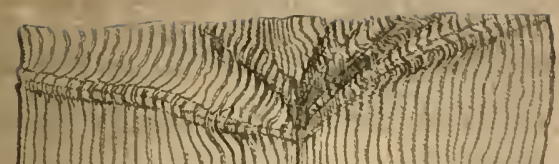

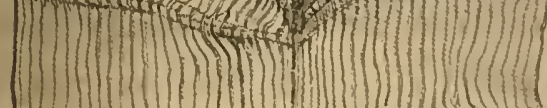

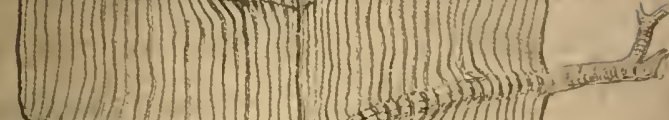

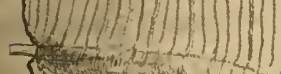

(1) $1(1)$

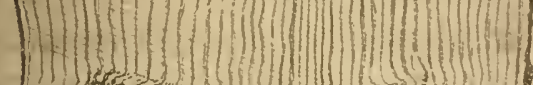

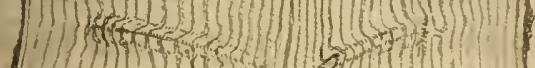
(2) 


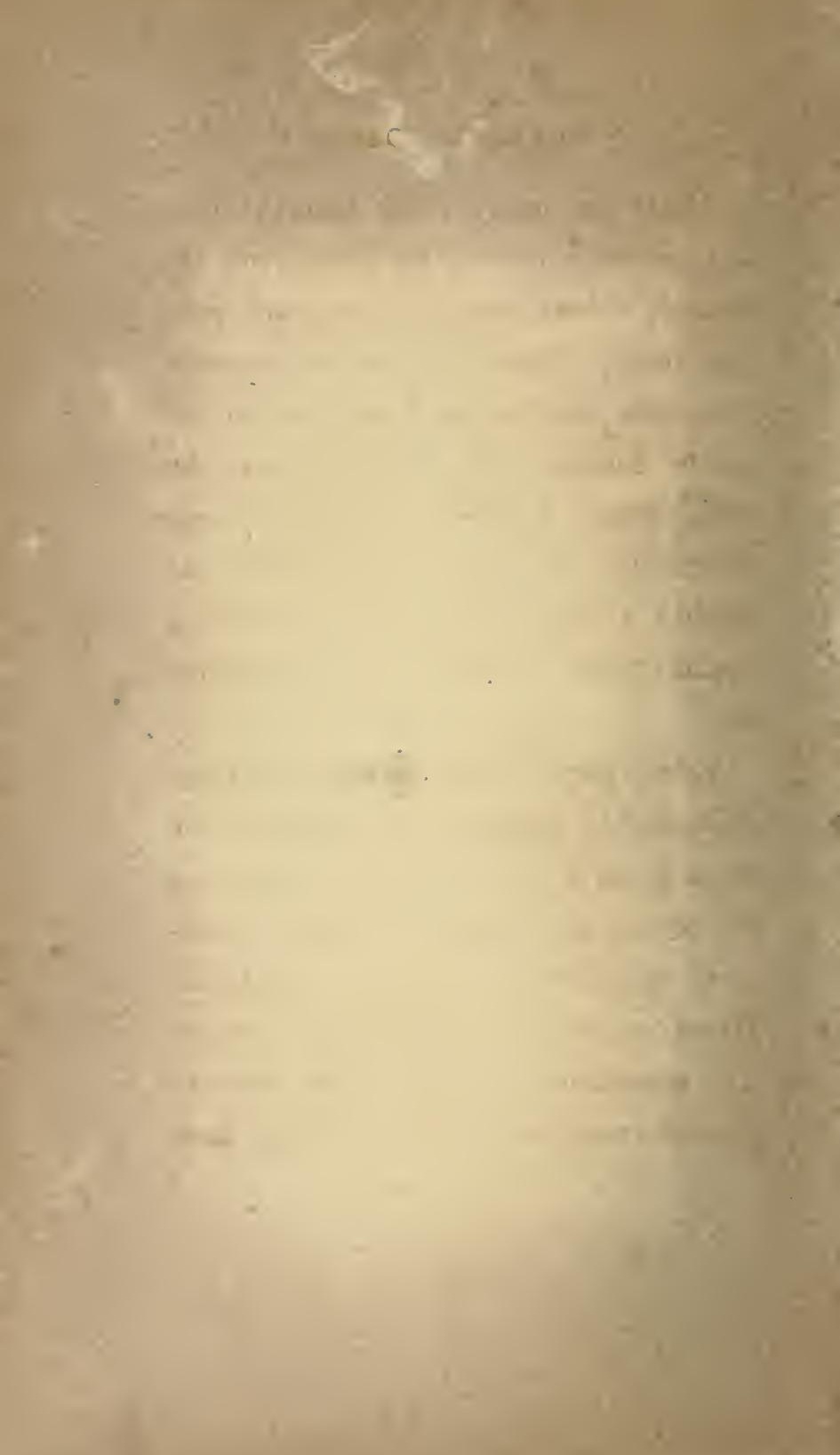


There are many other insects which are injurious to trees by destroying the foliage, young shoots, bark, and even the sound timber of sereral species. But these attacks on forest trees are all out of human power to prevent; for eren when known, the capture and destruction of a few individuals can go but a very little way in decreasing the myriads which wing the summer air.

Trees, particularly the elm, are often disbarked by horses in the winter season when grass is short. Train oil, or coal tar, or any other nauseous liquor, brushed or sprinkled on, acts as a defence. Hares and rabbits, and even field-mice, are sometimes destructive to newlyplanted trees, by gnawing off the bark 

WOUNDED TREES.

near the ground. Traps, dogs, and guns are the most effectual assistants to the foresters in such cases. 


\section{CHAPTER VI.}

\section{QUALITIES OF TIMBER。}

The principal and most valuable qualities of timber are ponderosity, hardness, toughness, and durability.

Ponderosity is a proof that the ligneous structure is not only dense, but that the cellular and vascular tissues are closely compressed, and well filled with juice, either in a watery or resinous, or in a concreted state. The first H 2 
148 QUALITIES OF TIMBER.

is quickly evaporated; the wood shrinks, and the timber is considered inferior, because liable to decay if exposed to the weather. If the sap be resinous, it is but slowly fugitive unless it be exposed to an unusual degree of sun or fire heat. This is very apparent in pine timber, and its so perfect saturation with this kind of sap constitutes its chief value, as imparting to it both weight and durability. The sap of some trees, as the oak for instance, is partly watery and evaporable; but the greater part becomes concreted and remains for ages in the cellular membranes, which it solidifies and preserves, and hence its superior durability.

The hardness of timber depends on the closeness of the ligneous structure; the cells being well charged with con= 
creted sap, and impervious to air or any other fluid.

Toughness arises from the longitudinal strength of the fibres, and the yielding nature of the cellular matter in which the fibres are imbedded. The durability also depends on the size and strength of the fibres individually, and the compact manner in which they are imposed on each other, and all united by a resinous or concreted juice.

All kinds of timber are much heavier when recently cut than when seasoned. This is owing to their being replete with sap in the former condition, and dirested of it in the latter. Some species part with their moisture sooner than others: the willow and poplar when cut into boards are quickly dried; their sap being watery, is exhaled away in a very short 
150 QUALITIES OF TIMBER.

time; but the elm, which has a more glutinous sap, is dissipated so very slowly, that it continues to shrink for twenty years after being used as weatherboarding. Oak and pine timber lose but little of their bulk in seasoning; because they have but little aqueous sap to lose.

All the hardest and most durable kinds of timber used in the arts, as lignum-vitæ, ebony, yew, \&c. are diminutive slow-growing trees. Hence it has been held, that the slower a tree of any kind grows, the harder and more durable must be the timber. This may probably be the case in respect of the Scotch pine on its native mountains in the north of Europe. But in respect of English-grown oak, the very reverse is found to be the case: the quickest grown 
trees are always greatly superior to those of slow growth. A stunted oak produced on a dry hill is always found of a milder grain and less tenacious texture than the more luxuriant trees of the rich valley.

This circumstance has been proved in the dockyards: and hence an argument has been raised, that the best land and most careful preparation of the soil is absolutely necessary in order to raise oak timber of the best quality. For it is quite reasonable to conclude that free and vigorous growth not only amplifies the whole system, but each member is engrossed accordingly. The cellular and vascular fabric will not only be more coarse, but the fibres individually will be enlarged; and on the 
individual and aggregate bulk of these the real strength of the timber depends.

It is the united properties of solidity and longitudinal strength which render free-grown oak so indispensable to the ship and house builder ; its durability in the open air excelling all others, the American acacia, perhaps, excepted. Many inferior kinds of timber, if preserved from the worm and from moisture, continue sound for ages: and the sorts which are usually converted into household furniture may be worn out, but do not fail by decomposition. Some of the foreign kinds of wood, such as lignumvitæ and mahogany, are almost imperishable if kept with care and free from damp: These are durable from the extreme closeness of their grain, and from being always kept dry. 
But absolute dryness has not the same effect on all kinds of timber: some which gradually perish when exposed to the changes of weather, are rendered indestructible by being constantly submerged in water. Of these the beech and alder may be instanced as being remarkably durable as piles and other under-water scantling about wears, mills, bridges, \&c.

But timber is most highly valued that can endure all weathers;-where it is parched by the sun and soaked by the rain-exposed to the alternating temperature of night and day, summer and winter. In such circumstances, the lasting properties of timber for ship-building, fencing, canals, bridges, carriages, \&c., are invaluable. The naval oak of Britain, the teck of India, and the aca- 
154 QUALITIES OF TIMBER.

cia and a few others of America, are all remarkable for their durability and fitness for ship-building, and all other structures constantly exposed to the wèather.

It may just be remarked, that the juices or qualities of the oak tree are fatal to fish. Oak posts used about bridges or wears, or embankments of rivers, will cause all the fish to leave these haunts. And if a tree be blown or felled into a pond, and not removed quickly, every fish, if any, will perish in a few days. And if cows be brought down from a country where no oak grows, and turned into a pasture where these trees are common, they, the cows, will be sure to suffer from the disorder called the red-nater.

Durability, it is evident, as already observed, is owing to the compactness 
and strength of the fibrous components of the wood, and to the preservative qualities of the sap respectively. That of the oak is strongly impregnated with an astringent tanning principle, which, when extracted, is so well known to give durability to whatever vegetable or animal substances are saturated therewith. Besides, there is a ferrugineous quality in oak timber which may be another agent in its preservation. One of the most trying circumstances in which timber of any kind can be placerl, is what is commonly termed "between wind and water." An oaken gate-post nine inches square remains sound for about forty years; but then, or soon after that period, requires spurring; while neither the parts deep in the ground or entirely in the air are much decayed. 
156 QUALITIES OF TIMBER.

Oak beams, and other scantling in buildings, are known to last for several centuries. In some of the old halls and abbeys the oak timbers are still sound. Some of the beams are said to be Spanish chestmut, detectable by leaving no stain on edge-tools employed in trying them. Some builders doubt whether this really be as reported; they conceiving that those timbers which appear to be different, are two kinds of oak rather than that one of them is chestnut. This question is not yet decided; opinions being various and conflicting.

In "A Treatise on the Acacia," by W. Withers, Esq. of Holt, Norfolk, the author gives a statement of the comparative strength of timber, as prored by a gentleman in the Woolwich dockyard; 
QUALITIES OF TIMBER.

-viz. the best oak is 1672 ; acacia, 1867; ash, 2026; beech, 1556; elm, 1013; Riga fir, 1108; Madeira larch, 1000 ; spruce fir, 1474; and teak, 2462. These proofs are obtained by submitting square pieces of exactly the same dimension of the different kinds, to weights laid upon them, while supported by props at each end, in a horizontal position; the weights being gradually added until the piece breaks.

This test proves the strength or toughness of the wood, rather than its durability: though these properties are often, but not always united.

Within these last twenty years very general complaints have been made of the inferiority of oak timber used in the dockyards during that period. It is said that it is less durable than it used to be 
in times past, and much more liable to the dry-rot. Ships built of the very best seasoned timber, and which remained for several years on the stocks, actually required repairs before they were launched! Several new ships which had been but a year or two in commission were condemned as unworthy and broken up.

Many different reasons were assigned as the cause of this sudden decay of what was considered the very best hearty oak. Imperfect seasoning, mentioned as one cause, could not be maintained, as the scantling was cut and exposed to the air for eight or ten years before it was used. Particular orders were issued from the Admiralty relative to this point of preparation of the scantling: in fact, this precaution had been long and uni- 
formly acted on, and still failures occurred where least expected.

Another reason was, that a great quantity of the oak timber used in the dockyards of late years was from trees planted in the seventeenth century, and therefore wanted age to mature and harden the woorl; and moreorer, that trees nursed up on well-prepared ground, thereby insuring rapid growth, must necessarily be inferior in quality to the old and slower grown residents of the natural woods. This reasoning, however, was never supported by actual proof.

But there was yet another idea entertained; which was this, - that there being, as already noticed, two kinds (some botanists liave made them distinct species!) found everywhere in oak 
woods,-namely, Quercus sessiliflora, stemless-flowered oak, and Quercus pedunculata, stem-flowered oak [9] [9], the one was supposed to be much inferior in the durability of its timber to the other; and according as oak scantling was more or less lasting, it was said to be the one or the other. But which of the two was the true British naval oak was not readily decided. Some planters believed, as the last-named was of quicker growth, and ultimately formed the handsomest tree, and also was most frequently met with in woods and plantations, that it was the true British oak. But an opposite opinion has been held; and that is, that the Quercus robur, or navalis, Q. sessilifiora, yields the most durable timber: and if the opinion of one of the most eminent architects in 
the kingdom can have any weight in this question, the fact is really as he states; namely, that the $Q$. sessiliflora is the real British oak.

That such a distinction has not been earlier made, is not much to be wondered at: the botanical distinction, and that only very lately announced, is of no value, as both stalked and stalkless acorns are sometimes found on the same tree. The woodman and carpenter must be allowed to be the only competent judges of this question; and as the architect above alluded to has spent his life among these men, he must be accounted a pretty good authority. It is more than probable, however, that Mr. Loudon, in his Arboretum et Fruticetum Britannicum, lately published, will have set this important question at rest. 
That the Quercus pedunculata is more frequently met with in our plantations, may be accounted for from the greater facility of gathering their acorns than those of the $Q$. sessiliflora; and the former being also generally larger, they are preferred by the pickers when fallen to the ground. Of course they are more generally cultivated in public nurseries, for sale; and hence their greater abundance.

That there are certain districts in this country more famed for fine oak than others, has been discovered by the carpenters in the dockyards. There is, it seems, a tract of land in the counties of Kent and Sussex which yields oak timber of very superior quality; and whether the sticks be of small or large dimensions, the heart-wood is always 
QUALITIES OF TIMBER.

163

found of excellent quality. This is owing to the suitableness of the soil; it being a rich loam upon a subsoil of blue clay, in which the oxide of iron is predominant, and which is supposed to be particularly congenial to the oak. Indeed, it is universally admitted that, as already observed, all clayey subsoils are farourable to the growth of this tree.

The ravages of dry-rot being now much more frequent and extensive than formerly, has induced some persons to imagine that this dreaded fungus $(M e-$ rulius lachrymans) has become everywhere much more prevalent than heretofore. It is questionable, however, whether this fungus seizes perfectly seasoned timber: that it destroys that which was supposed to be tholoughly seasoned, is well known; but 
it is assumed that the merulius is not the cause, but only the companion of the rot. All other fungi are only found on dead or dying animal or vegetable substances; it is their natural office to devour or decompose all putrid or putrifying matter; and therefore, it is argued that there must be some predisposing defect in the timber, before the seizure of the merulius.

But what defect can sound timber be liable to while in the seasoning shed? It is answered, that if a tree be felled when full of newly-absorbed sap, some kind of chemical action takes place therein, producing a diseased state of the timber, and, consequently, an attractive bed for the attack of the fungus. And this attack and previous corruption of the wood has been attributed to the improper time at which oak timber is 
usually felled; namely, in the spring for the sake of the bark, instead of in the winter when the sap is said "to be down." As a remedy for this, it has been advised to strip off the bark in spring while the tree is standing, and fell the tree in the following winter. This has been practised, but with what good result has not generally been made public.

Neither can we conclude that this management is of any real benefit. The removal of the bark suon arrests the growth; but as this cannot be easily removed until the cambium begins to swell and the sap is in full flow, the ob. ject of those who approve of winter-felled timber is defeated. And besides, the body of the tree, and particularly the last two or three layers of alburnum, will continue to inhale moisture from the roots 
throughout the summer, notwithstanding the loss of the bark. It is true that the outer layers of alburnum when thus exposed become, from the summer sun, sooner dried; but these outer layers being what the carpenters call sap-wood, are always rejected and hewn off the hearttimber.

And again, those who imagine that the sap descends to the roots in winter, and therefore that the wood is sapless during that season, must prove two attending circumstances which have never yet, we believe, met the practical eye; namely, that the head of the tree is destititute of sap during winter, and that the roots are surcharged with it in the same season: these circumstances, however, have never been observed. The fact appears to be, that the sap in winter is more coagulated and less fluid 
than in summer; and, consequently, when felled in winter, the sap is very gradually exhaled, and the wood is less subject to rend;-whereas, when felled in summer, the watery sap is quickly exhaled by the heat of the season, and presents many cracks from the sudden shrinking of the rood. That this is the sole adrantage of winter-felling, is provable by the fact that trees having a resinous, and, consesequently, a slowly exhalable sap, may be felled in summer without being liable to the same disruption of the texture as trees having a watery sap.

In treating of the growth and management of forest trees, it is impossible to overlook the ideas commonly entertained respecting the motions of the sap. The old opinion promulgated 
by the earlier physiologists was, that the sap taken up by the roots ascended during summer, and receded into them again in autumn, there to rest till the return of spring.

The ascent was said to be through the tubular stiucture of the wood, and the descent through the lamina, or layers of the bark.

After the circulation of the blood in animals was discovered, a similar movement of the sap was supposed to take place in plants. But as no propelling organ could be found in the latter, like the heart in animals, the notion of a circulation was abandoned; but still the idea of an ascent and descent is maintained.

These counter-currents through the same or contiguous ressels have never been clearly explained; nor can such 


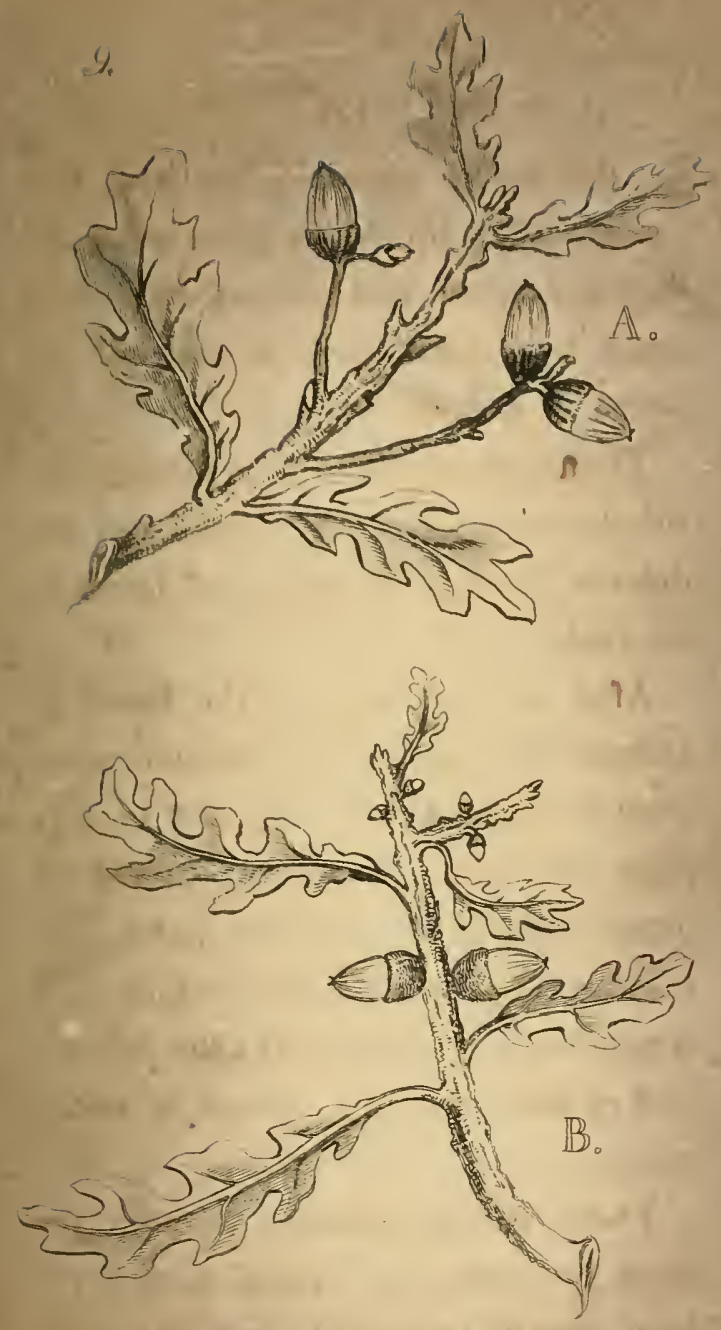


a process be easily conceived. But modern physiologists have discovered, or rather conceived, that the leaves are the returning organs; that simple sap arising from the roots is received into the leaves-is there elaborated-becomes heavier, and obeying the law of gravitation, sinks from the leaves, and forming as it descends the new zones of wood and liber on the branches and stem, and the new layer of wood on the roots.

This is the modern opinion, and is so taught in our universities by the learned professors. It is a point of botanical knowledge which is seemingly "taken for granted," and appears to be received through sheer complaisance, as no proof is given by the propounders, nor required by the students. No one denies the ascent of the sap, because it is self- 
170 QUALITIES OF TIMBER.

evident; and to account for the descent, the most perplexing tests are brought forward to prove the possibility of this invisible process.

The most rational idea, perhaps, concerning the nature and motions of the sap is, that in whatever state it is received into the system by the roots, it becomes assimilated to the essential juices by the natural chemistry of the plant, and in that state is diffusable in all directions through the various membranes; that it is liquefied and expansible by heat, and coagulated by cold; and that it is the vivifying constituent of a plant answering the same purpose in the economy of a vegetable, as the blood does in that of animals.

Whatever may be the real cause that oak timber is less durable than it was 
formerly considered and proved to be, is at present a most interesting question; and so little can builders depend upon its lasting qualities, that chemistry has been called to aid the builder in securing his ground timbers from dry-rot.

The cause of dry-rot is attributed to a fungus of a rery delicate nature; and therefore it was very natural to suppose that it would be either killed or banished by some kind of mineral poison laid upon the scantling intended to be placed where it would be subject to the attack.

It has been long ago obserred that wooden ressels, in which metallic solutions of various kinds were kept, or which were used by the manufacturers of metallic pigments, became almost imperishable; but (as has been observ- 
172 QUALITIES OF TIMBER.

ed by a late writer) "Mr. Kyan was the first person who took advantage of this property and rendered it economically important. He steeps the timber in an aqueous solution of corrosive sublimate; and it is found that this salt, by entering into chemical combination with the perishable juice of the plant, converts it into a substance which not only arrests the malady of the timber which attracts the fungus, but forms a surface on which it cannot grow."

This discovery may be productive of the most beneficial consequences, especially in the nary; but it is hoped that a solution of a less poisonous mineral may be found equally serviceable in preserving timber from dry-rot, and also that some method may be devised of saturating the interior of the scantling as well as the surface. 
I had written thus far when the Prize Essays and Transactions of the Highland and Agricultural Society of Scotland, published in the 39th number of the Quarterly Sournal of Agriculture, came to hand. In this publication I was much gratified to see the opinions of five rery competent judges of the subject on which I was myself engaged, and of course gave the whole a careful perusal; and it is no small satisfaction to me to find that so many of my practical brethren agree with me in all the more important points relative to the management and necessity of pruning forest tirees. The phenomena of the growth, and the good effects of timely pruning, and the bad consequences of neglecting it altogether, described in the sereral essays under notice, compared 
174 QUALITIES OF TIMBER.

with what has been already advanced in the preceding pages, will be found to agree most accurately. We only differ a little about the powers and properties of the sap; but, as different opinions on this point of vegetable physiology do not, nor cannot affect the actual processes of the intelligent pruner, it signifies little how such a point is understood.

There is a little discrepancy of opinion among the essayists, as well as that of their compiler, relative to the proper season at which pruning should be performed; but every one who is acquainted with the manner of the accretion of a dicotyledonous stem must perceive that the commencement of the spring growth-that is, just as the buds begin to burst_-is the only proper season, 
because, as one of the writers says, truly, the wound "begins to heal from the moment it is made ;" and therefore autumn and winter pruning, which exposes the naked wood for sereral months, must be more or less injurious. It must be remembered that the membrane which covers the wound begins to expand at the same time with the buds; and therefore, when a wound is made, the nearer the operation is to the commencement of the growth, either before or after, the sooner the wound is healed.

The time chosen for grafting trees is a practical instance of how soon a wound is healed when made about the time the vital membrane begins to swell; and which operation is quite practical throughout the spring months. Budding is 
176 QUALITIES OF TIMBER.

performed later, lest the buds should burst too soon, and be liable to be killed by the frost of winter: but both operations are successful entirely from the union which is formed between the swelling membranes of the respective parts. Wood and wood, however full of sap, can never unite; neither can bark and bark form a union: it is the living glutinous membrane situated between the wood and the bark which coalesces and forms the junction. 


\section{CHAP'TER VII.}

ON COPPICE WOODS.

Forest trees are not only cultivated for the purpose of the builder; they are also useful and valuable as coppice or underwood. And as underwoor yields an annual revenue, it is, perhaps, in the long-run quite as valuable a possession as a wood of full-grown trees. The slender stems or shoots are useful for many rural and other purposes; from the willow rods for basket-makers, up to the oak poles for fencing. Poles are indispensable to the hop-grower, to the 
hirdle-maker, to the rake, mop, and broom-handle makers, and especially to the hedger and hoop-maker; and together with what are required by the above tradesmen, the refuse is bound up into fagots of different sizes, and for different purposes, as fuel, all of which meet a ready sale.

Experience has determined what kinds of trees are best adapted for underwood. Poles are valued for their length, toughness, and durability; and whether they are five or fifteen feet long, if straight and knotless, the more valuable they are. The ash is perhaps the best, or one of the best, calculated of all others : for, added to its quickness of growth may be reckoned its uniform straightness and toughness. Superior to the ash in durability, and almost equal to 
it in the straightness and number of its shoots, ranks the Spanish or sweet chestnut. This plant is but little known in rural economy, except in some parts of the county of Kent, as proper for coppice; but it deserves every attention of the planter. The white or Huntingdon willow is a quick-growing and profitable sort, both as an inferior timber and as underwood, as well as its congener the crack willow: both yield very fine poles. Birch is a useful underwood plant; it yields poles, stakes, and excellent withes or bands for binding fagots, \&c.; and its spray is the best of all material for making stablebrooms. The common hazel is also a good coppice plant, as it also yields stakes, headers, and withes in abundance. 
Beech and hornbeam coppice is felled periodically, and the produce is used by the charcoal manufacturer and by the brickmaker.

In speaking of coppice, we cannot forget how highly the acacia (Robinia pseud-acacia) has been extolled as a coppice plant by the late $\mathrm{Mr}$. W. Cobbett. He declares that poles of this tree are almost equal in durability to iron. Whether what he recommended and arowed concerning the tree has been put to the proof in this country, we know not; but if only half be true which Mr. Cobbett and the American builders assert of its imperishable properties, it is well deserving of a trial. In ornamental plantations we have long been acquainted with the tree. It thrives well in dry loamy gravels, grows rapirlly when 
young; but when it attains the height of twenty-fire or thirty feet, it becomes stationary, and grows very slowly afterwards. Trees of British growth felled when fifty years old are about a foot in diameter, the bole about twelve feet high, bearing a thinly-branched head, but of a very picturesque character. The timber in colour, solidity, and hardness answers Mr. Cobbett's description; but the parts which we saw converted to use have not been long enough tried to establish their durability as reported by Mr. Cobbett.

Its liability of being broken by the wind when young, as mentioned elsewhere, is against its eligiblity for coppice, unless the trees are planted and allowed to shoot up very closely together; but if its merits of lastingness be as 
reported, its culture as coppice would be of rast benefit to the hop-grower.

Oak coppice occupies large tracts of land, but, from its slower and crooked growth, is less adapted for furnishing poles or other pieces of straight growth; but being allowed to stand longer than other kinds of coppice, some of the principal wavers being left for timber, it yields, when felled, much useful material for fencing, besides the bark, which constistutes a principal part of its value.

The greater portion of coppice wood met with in Britain appears to have been formed by accident rather than by design, and seems rather to be the remains of ancient forests than productions of the planter. Nevertheless, it is quite evident that planted underwood, whether by seed sown or young trees 
planted, turns out ultimately the best and by far the most profitable of all wood-land. In self-formed coppice, there is always much vacant ground between the stools. This circumstance not only reduces the quantity of the crop of poles, but also renders the crop less valuatble, in consequence of so much horizontal growth occurring between the stools, whereby the poles proceeding from their outsides are so crooked as to be fit only for firewood. But when the stools stand near together, every shoot from them rises upright, and they aggregately advance like a crop of corn, equal in size and height; and this more especially when the same kind of tree is chosen, and without intermixture of others.

It is usually damp or inaccessible portions of an estate that are appro- 
priated to the growth of underwood. Low and fenny tracts on the banks of sluggish rivers are generally occupied by willow-holts. The surface is laid into narrow beds by the spade; and one or two ranks of cuttings are dibbed along the beds. The common red ozier is one of the most productive for the basket-maker, for whom the shoots are cut every year.

Where the soil is loamy, but too wet to be kept arable or fit for sound pasture, laying it down in underwood is the best way of disposing of it. If very wet, it may be laid into beds, as is done for willows: and the beds may be more or less in breadth, according to the condition of the soil as to wetness. Whether ash or sweet chestnut be preferred, the plants may be placed in rows 
along the beds as near as three feet from each other, and be allowed to grow up into useful stuff before they are cut for the first time. On such a soil, willow, birch, or oak will thrive equally well.

It is a very common practice to grow timber and underwood on the same spot: and where the trees or groups grow at good distances apart and have their lower branches pruned back, they injure the coppice but very little. A few groups of trees, irregularly disposed, give a coppice a highly interesting aspect, as breaking its monotonous character, and giving it the semblance of forest scenery.

A well-planted and productive piece of underwood has been considered as not unworthy of the pruner's care. 
After a fall, a much greater number of shoots always spring up from the stools than can possibly come to perfection, or continue to live beyond the third year. This is an exhaustion of the stools for no good purpose; and therefore it has been advised that the stools should be looked over after the second year's growth, and divested of all weakly and supernumerary shoots, leaving as many principals only as will suffice for a full crop without crowding so as to injure each other.

This may be thought a tedious and unnecessary business: but the superior stuff which would be produced by such a regulation, would soon convince the forester that he had not laboured in vain-especially if the extra shoots are slipped off; if cut off, the buds at their 


$$
\text { ON COPPICE WOODS. } 187
$$

base quickly sprout again. A gradual thinning of the coppice also allows the option of having the poles of the most profitable size. 


\section{CHAPTER VIII.}

ON PRUNING THE PINE AND FIR TRIBES.

The foregoing observations chiefly relate to the pruning of deciduous forest trees: but it remains to add somewhat on the method of managing the different hardy species of the Coniferæ-that is, the various kinds of fir and pine timber usually cultivated in Britain.

As no kind of timber is more generally useful to the builder, so neither is any other sort so liable to be deteriorated by knots occasioned by the want of 
pruning. Most of the species are very regular in their manner of growth ; gaining altitude by annual gradations of the leading shoot, and, at the same time, producing from three to six branches, issuing from the base of the leader. This aggregation of the branches originates as many knots in the bole, and causes derangement of the longitudinal grain, and consequently reduces its value for every purpose of the builder. The larger these knots are, the less valuable is the timber ; and if a branch dies and remains long attached before it falls off, a dead, or cork knot, is the consequence. As all branches originate at the pith, the sooner they are displaced, either by art or accident, the less is the damage to the wood; and hence the finest $\operatorname{logs}$ of pine and fir are 
drawn from woods where the trees have stood closely together, or have been carefully pruned up during their early growth.

Any individual tree of this tribe, standing singly in an open space, assumes its natural form, and is either lighly ornamental or picturesque, and thickly branched from top to bottom; but such boles are the most inferior of all when brought to the sawpit. The wood is so distorted by large knots, that it is only fit for firewood.

The most beautiful specimens of the Coniferæe are grown on lawns, where they have full air and room to spread; the lower branches resting on the ground, and in which some of the species (as the common spruce, for instance) strike roots, and thence send up new stems. 
In like situations the silver fir and Weymouth pine become magnificent trees; and even the Scotch pine, if dirested of its six or seven lower tiers of branches, becomes at last a highly ornamental object when fully feathered to the ground.

But the finest fir timber grown in this country, or indeed in any other, is produced by close planting in considerable masses-the more extensive the better. The border of this plantation should be formed of several ranks of spruce firs planted at greater distances than those in the interior. This is to encourage more bushy growth; and to ensure and continue a thickened margin, the leading shoots of the first and second ranks on the exterior should be cut off at different heights, to increase and 
thicken the branching below. With such a boundary affording the necessary degree of shelter on every side, the trees within will rise rapidly and equally, and if kept duly pruned will becone valuable butts of timber.

Our knowledge of such kind of woods is drawn from the view of plantations made in different parts of the country about one hundred years back. Where these trees have grown up pretty close together, they have pruned each other, and are now tall and so far valuable trees; but where they hare stood thinly, they are stag-hearled, branched a good way down the trunk, and inferior both in quantity and quality of their convertible bulk. From these plantations of Scotch fir, it rery plainly appears that they should be very gradually and cau- 
s.
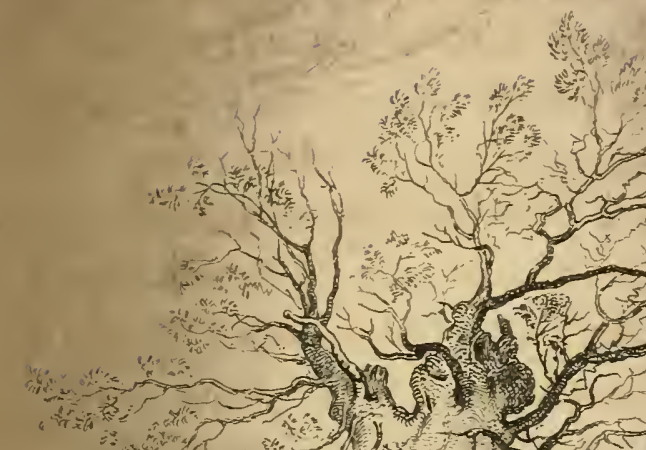

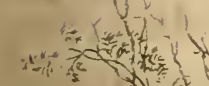
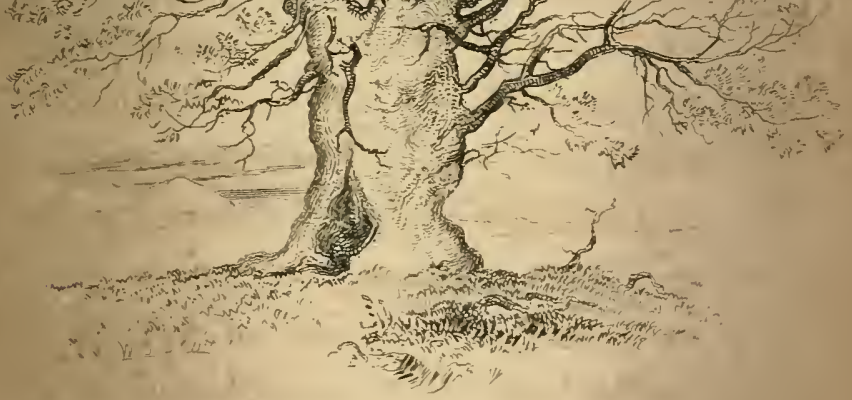


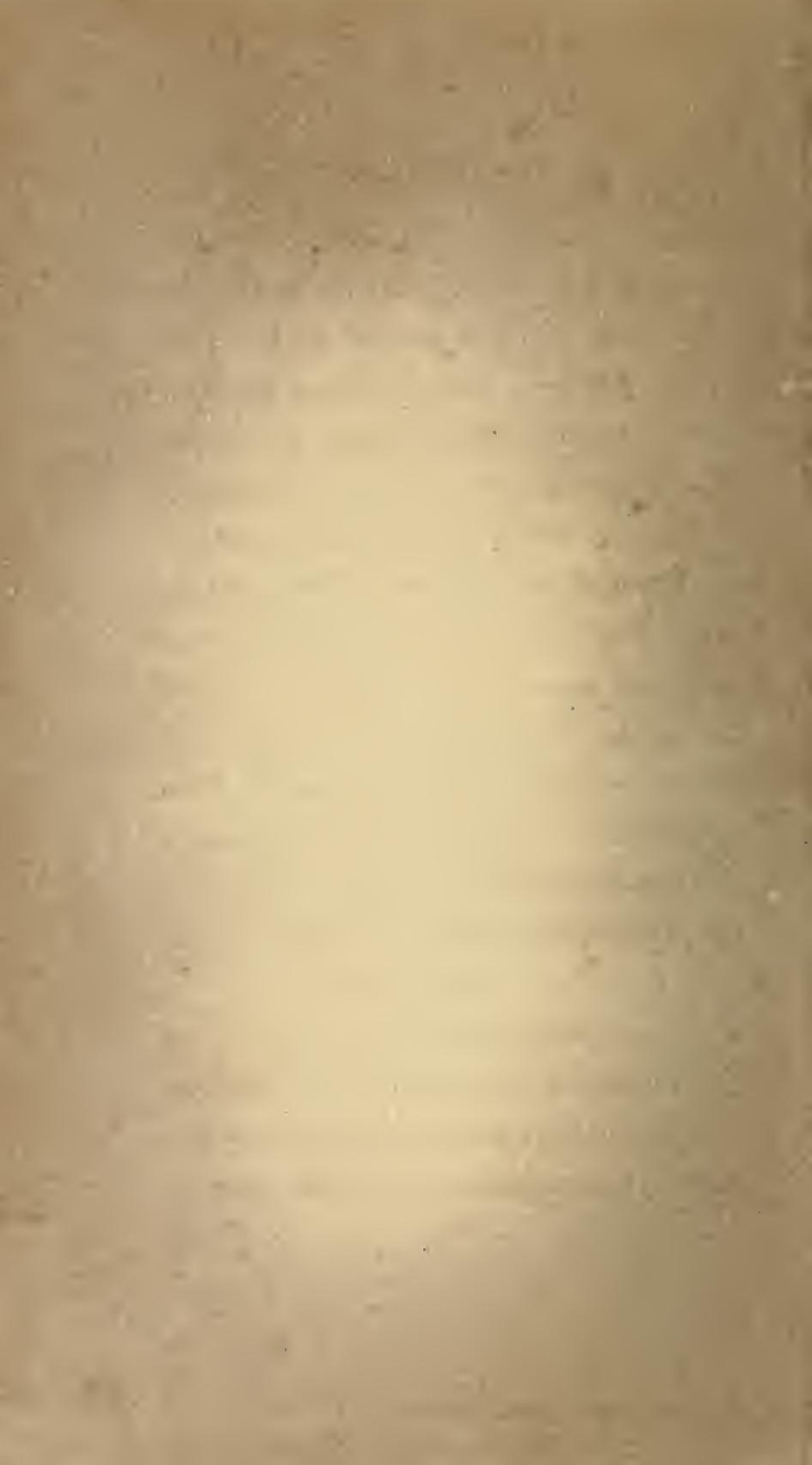


tiously thimned. They suffer from sudden exposure; and we have often seen that where a part of such a plantation has been felled for any particular purpose, the whole began to decline, the exposed trees dying off annually while any of the originals remained.

From this circumstance it would appear that when such a plantation is made as an object of profit, they should either be very sparingly thimned, or allowed to stand till they are all felled together. The shattered remains of a fir plantation are the ugliest objects in a landscape: they seldom live to improve, and are self-condemned.

Many estates have been embellisher by numerous clumps of firs of different kinds; but notwithstanding that they give a dressy appearance to a naked country, 
they are generally condemned as ornamental features, because of their gloomy hue, and overbearing effects on all undergrowths. Some proprietors have endeavoured to supplant the firs by a gradual introduction of deciduous kinds in every vacancy; though the association is not a-pleasing one to the eye of taste, as the foliage of the two do not harmonise. But it is the best plan that can be adopted when firs are intended to be supplanted or surrounded by more beautiful trees.

But to return to the most eligible methor of pruning firs for profit:-and first, it may be observed that as the lower part of the bole is the most valuable portion of the tree, it is this which requires the most attention; and as this is always within convenient 
reach of the pruner, it is inexcusable if neglected. It has already been observed, that every branch leaves a knot in the body of the tree; - that the younger and smaller the branch, the smaller the knot is, and also the nearer the pith. This shows that the earlier the branches are removed, the fewer blemishes will be in the timber; and, consequently, the sooner the business is begun the better.

As soon, therefore, as the trees are fire feet high, the pruning may be commenced by cutting off closely the lowest tier of branches, and also one or two from each of the tiers above. The object of the last manœurre is to prevent too many knots appearing together at the same place in the butt; always accounted a defect to which fir timber,

$$
\text { K } 2
$$


from its manner of growth, is particularly liable. As the branching of firs is in distinct tiers or sets, many foresters have laid down rules for pruning off the sets seriatim : some leave only three tiers to form the head, pruning close off all below; others think three tiers on the head too small a number, and advise four at least to be retained.

It is very certain that much depends on a just method of pruning being bestowed on every forest tree, and particularly firs. The capacity and exertions of the roots are always in proportion to the demands of the head; and if the latter be too much reduced, the roots must receive a check, and remain inactive, in consequence of there not being a full demand upon them. Deprive a fir tree of its head and every 
branch, and the whole system dies. Do the same to deciduous kinds, and they soon will be refurnished with numerous shoots and branches. If a deciduous tree be pruned up to a small head, its sap and vigour is wasted in the production of numerous small shoots from the stem; but if a fir received the like treatment, it would be completely paralysed, if not entirely killed.

It is on this account, therefore, that in pruning firs care must be taken not to check the growth of the tree by immoderate dismemberment, nor allow the timber to be deteriorated by an unnecessary number of branches. It must be admitted that this endeavour to grow the most valuable timber reduces the bulk of the trunk; but without such management it is impossible to grow 
superior deal timber in this country. Yet a clear-grained butt, notwithstanding its want of bulk, will always be of more value than one full of knots, whatever may be its size.

The rule (in pruning a close plantation of firs grown for profit) is to cut off annually every lower tier of branches, so as to leave four or five tiers to form the head. This proportion will induce a necessary action in the head as well as in the roots ; and both progress together, mutually contributing to advance the tree to its natural amplitude. This size of head for trees standing at twelvefeet distances will form a close canopy overhead, and prevent all undergrowth whether of branches on the bole or of inferior plants on the ground. The growth of the trees will be equal, few 
gaining an ascendancy over the others: so that they will be all fellable at the same time.

Some of the other sorts of the Coniferæ grown in this country are mole irregularly branched than the Scotch fir; and though they arrive at a greater bulk of bole, the timber is inferior, and oniy fit for quarters in partitions. If the same pains, however, are bestowed in pruning them when young, their timber is much improved in quality, and fit for many purposes of the joiner, trunk and cabinet maker. Their value as ornamental trees has already been alluded to.

The most ornamental species of the Coniferæ are the cedar of Lebanon, the deciduous cypress, the hemlock spruce, the white spruce, and silver fir; the cembra and Weymouth pines are all 
proper for dressed grounds. The stone pine and pineaster are lumpy-headed trees, and are good for forming skreens or sheltering boundaries and nurses for other more tender plants. But the two most useful species are the Scotch fir and the larch, particularly the latter for growing into profit. This alpine species is extremely hardy, is of quick growth, and succeeds on poor thin soils where scarcely any other trees will grow. Its timber is tough and durable, and ships which have been built of larch timber remain nearly as sound and sea-worthy, as far as present experience goes, as those built of oak. No tree has been more extensively planted than this, particularly in the North of England, Scotland, and Ireland; and which promises to be a source of considerable wealth to 
the owners for ages to come; and if larch timber be found worthy of being used as a substitute for oak in shipbuilding, the tree will be of immense benefit to the nation at large. Larch plantations have been generally successful; but within these last ten years some of these trees have suddenly become subject to a disease so fatal that every tree is ruined by it. This is rottenness at the core- the solid timber being decomposed, and so much so that it may be rubbed into dust with the fingers. This defect has only appeared partially; but whenever it has shown itself, trees of all sizes and ages are infected. In some few instances every tree has failed, so that the whole have been cleared off, root and branch, and the ground replanted with other kinds of trees. 
202 ON PRUNING THE PINE

The attention of the first phytologists, both in England and Scotland, has been directed to this malady, and every means used to discover the cause, with a view to provide a remedy against the attack, but hitherto without any satisfactory result. That the cause is neither in the soil generally, nor in the atmosphere, is evident from its very partial attack of, perhpas, only one in a score; and this only in certain districts, for as yet the disease has only been endemical. Whether it exists in the South of England no reports, as yet, have been made public; but it may exist though not discovered, because there is scarcely any sign that the defect has begun till the tree is felled.

What makes the failure of the larch more remarkable is, in being so different 
from the manner in which congenerous trees usually fail. When a Scotch fir dies, it is the bark and alburnum that first loses vitality, while the heart-wood is as sound as ever; which may be owing to the greater quantity of resinous sap concreted in the centre of the bole. By analogy it might be supposed that the larch is similarly constituted: but in the case under consideration it is quite the reverse; the centre of the larch dies, while the exterior is alive and thriving.

It has been observed that in the rast plantations of this tree at Dunkeld, a seat of the Duke of Athol, the deadhearted trees are mostly found on the wettest parts of the hills; but this observation has not been confirmed by the experience of others who have paid attention to this fatal malady. 
This circumstance has led to the sup. position that the resinous juices of the larch are decomposable or destructible by being combined with some extraneous fluid, the source of which remains undiscorered. We remember the time when the health and thriftiness of almost all the larch trees in the kingdom were checked, and the rery lives of the trees in jeopardy, from the attack of a small mealy coccus or aphis, which in myriads fixed themselves on the young shoots and leaves for two or three years successively, and if they had continued for a year or two longer, would have eventually killed the trees. But the insects disappeared at last, and the trees quickly recovered. So it is to be hoped that the present malady of the larch is only epidemic, and will also soon disappear, 
although the cause of it is much more inexplicable than was the attack of the coccus.

Larches need but little pruning, only requiring to be kept free from dead twigs and boughs, which, if not cleared off the lower part of the butt, injure the grain of the wood. The small twigs die naturally, and most of them drop off themselves; but they should not be allowed to remain after they are dead, because the new layers growing over, and the stumps becoming buried in the new wood, of course occasion flaws in the interior.

It is worth observing, that even dead knots in fir timber are of less consequence in the working up, than are those in other kinds of trees; because the resinous sap surrounds and saturates 
the dead knot, and renders it as firm under the plane, and almost as durable, if unexposed to heat, as the rest of the wood.

The longest-lifed species belonging to the Coniferæ is said to be the deciduous cypress (Taxodium): some of them in their native country are of an immense size, and supposed to have been growing for one thousand years! The majestic firs discovered by Douglass and others in California must also, from their vast size, be very aged trees. The longest-lifed European species is perhaps the common yew; some very aneient specimens being still in exist'ence, of which mention is made in very old records.

It is expected that several of the new foreign species may be so far naturalized 
as to be valuable additions to our groves and woods: but it is doubtful whether they will prove superior as useful timber to the kinds already introduced. But any doubt on this head will in a few years, it is likely, be cleared up. Many collections of the different species of the Coniferæe have lately been planted in Britain, for the express purpose of proving how far they will be useful to the planter. The Pinetums, as they are called, at the Royal Gardens of Kew, at Dropmore, at Woburn Abbey, and other places, are on a great scale, and will in a few years show decidedly which, and how far they deserve attention.

Sereral varieties of the Scotch fir have been introduced from the forests of Germany; and which, as seedlings, pro- 
208 PINE AND FIR, TRIBES.

mise to be of a more robust habit than our natives. This superiority may only arise, perhaps, from the change of seed and soil; but a few years will determine this point. 


\section{CHAPTER IX.}

POLLARD TREES.

Pollard trees are still in many parts of the country considered to be indispensable to the tenants of the land. They are grown in hedge-rows, and consist of oak, elm, or ash, and are lopped periodically, and usually when the hedges are made. On the redundant stuff from the hedge and loppings from the pollards, many farmers solely de- 
pend for poles, stakes, and headers for fencing, and fagots for fuel. Willow pollards are everywhere planted, in meadows, on the banks of rivers and sides of ditches. They yield every five, six, or seven years, considerable numbers of poles and stakes for hirdle-making and fencing; and as pollards, they neither shade much of the land, nor do they require fencing against any kind of cattle.

No greater improvement can be made on a farm on which there is not an acre or two of underwood, than stocking it well with pollard trees, particularly ash and willows. On dry grass-land, ash trees may be planted to rise into pollards, rather than be without poles and stakes for the use of the farm; but if any degree moist, the Huntingdon or crack 
willows are to be preferred, because of their being less destructive to the pasture, and because they are so easily established. Both these willows are readily raised by truncheons: stout full-grown poles are cut into lengths of nine or ten feet; holes are digged to the depth of two feet, in which the truncheons are set, and firmly fixed among the finely-broken soil. A guard, or wreath of thorns, is usually: bound round the stem, to prevent the rubbing of cattle till the truncheons are rooted.

When pollards are lopped, the poles, \&c. should be cut closely and smoothly off; as no prominent stumps should be left to produce the next crop of shoots.

Pollards in hedges are objected to as destructive of the fence; they are best planted on the opposite side of the ditch. 
But every farm should have, at least, one acre of underwood well enclosed, for the express purpose of growing fencing stuff; which is far better than having pollards scattered everywhere orer the fields. 


\section{CHAPTER X.}

LONGEVITY OF TREES.

ThE longevity of trees is a branch of phytological history of which we as yet know little or nothing; although no portion of that history would more redound to the profit of landholders than the knowledge of when a tree is at its best, and just on that stage at which it begins to decay.

Every tree and every part of a tree 
has only a temporary existence: from the moment at which it begins its derelopement, it also begins and continues verging to decay. Whether it be pith, or wood, or bark, all are doomed sooner or later to submit to decomposition, and return to their first elements. The first members which are produced from the seed are also the first to suffer decay. The pith is constantly declining from the first year, until it totally disappears. The bark is the next which surrencers vitality and its connexion with the system to which it belongs. In some cases, as in the vine, it is withered and dead, and thrown off every third or fourth year. The axis of wood is the most durable, and during its state of soundness undergoes several changes: on its first appearance it is as 
a thin transparent lymph called cambium; next it is called alburnum, or white or sap wood; afterwards it gains its greatest degree of hardness, and then it is called perfect or heart wood. In this last state it exists without change for a longer or shorter period of time, accordto the kind of tree, or quality of its concreted sap.

This period being uncertain, is that point concerning which it is so much our interest to have some certain knowledge. But all we as yet know on the subject is very rague. The wood in the generality of trees begins at last to decay at the core, and the decomposition increasing outwards, layer after layer perishes, till a rery thin cylinder of the surface only remains alive.

This natural decay happens sooner in 
some kinds of trees than in others. The willow is, perhaps, one of the shortest lifed trees; rottenness at the core happening very early, say in the sixth or eighth year from the planting. Some of the poplars are also subject to early decay at the heart. The English elm and ash may continue sound for probably fourscore years, and the oak and some of the pine tribe much longer.

It does not appear, however, that each kind of tree of the same age respectirely begins to decay at the same time. For in a fall of trees of the same species, in the same wood, and apparently of the same age, some individuals will be found perfectly sound, and others in a state of decay. Even in a fall of oak of like description, some are found red-hearted, (the first indication 
of radical failure,) while others are still healthy.

It is also well known that the nature of the soil affects the longevity of trees. We often see poplars, ash, \&c. dying at the end of fifteen or twenty years, while the same kinds are thriving vigorously on a different kind of soil. It is these varying circumstances which render the little knowledge we do possess relative to the mature age of trees so perplexing and uncertain.

There are no means of knowing when a tree is about to fail at the core. The defect is invisible, and continues to be so until the interior is in its most valuable part useless. It appears on examination of hollow trees, that the most central roots-that is, those which issue immediately from the under surface of 
the collet or base of the trunk-are the first that decay; and these dying, leave the parts to which they belonged naked and exposed to the damps of the soil, which probably originates the malarly.

Outward signs of this deterioration there are few or none: neither the young shoots nor foliage on the lower parts of the tree are affected by the injury within; in fact, these parts have no connexion with each other. As proof of this, we meet with many old hollow trees, both oak and elm, whose foliage is as fresh as ever. The first and only sign of a tree being defective at the core, is the gradual dying of the topmost branches; but this does not happen until long after destruction has been long going on. As soon, howerer, as such a sign appears, the trce should be felled. 
It is remarkable how long trees, particularly pollards, survive after being entirely destitute of almost the whole of their axis of timber. The annexed sketch is a portrait of a very ancient hedge-row pollard, the whole inside of which is decayed and gone, parts of the cutside only remaining alive to support the attenuated head of spray ; there being only tro or three of the last layers of alburnum (and each of these rery thin) to be found within the bark. Still this mere shell receives from the roots the necessary nutriment, conreys it to the shoots, the leares, and flowers and seeds of every stummer; showing decidedly that the wood is in the course of time deserted by the living principle, but which is always present between the bark and the alburnum as long as any 
portion of these members remain united and attached to a root.

Seeing, then, that the body of timber of every tree has only a temporary existence; that it is always useful for some purpose while going on to the time when decay commences, and of little comparative value afterwards; it should be the study of every forester to mark the trees to come down just before they begin to decay at the heart, were it possible he could by any means obtain such a useful piece of phytological information. For this is the practical point at which we wish to arrive; but, as already observed, we are yet in the dark respecting it, and merely because we have not published records of the exact time of planting or sowing the trees which are now everywhere falling under the 
axe. The life of any one man is too short to enable him to gain experience of the sowing, transplanting, progressive growth, and felling of the same trees: so that the proprietor who fells, and can discover the condition of his trees when down, rarely knows when they were planted - whether in the time of his grand or great-grandfather.

It so happens, however, that since planting has been so prevalent of late years, it is to be hoped accurate records have been kept, from which, at some future time, the lover of trees will be able to state of each kind the age at which they should be felled to the most advantage.

There is an old tradition signifying that the oak exists for three centuries; 
the first increasing, the second stationary, and the third falling to decay. This, perhaps, is only a specious supposition: but it may be, nerertheless, a pretty good practical rule; because an oak which has been growing for a hundred years on a congenial soil may certainly be considered as in its prime; and though it be still increasing in bulk, it would be hazardous to allow it to stand longer. There are, doubtless, many trees above that age which may be still sound; and many that may be deemed equally so will be found faulty when eut down.

It is a great drawback upon the satisfaction arising from the possession of fine old stately trees intended for sale, that notwithstanding their 
portly appearance while standing, they may be found defective when down.

One of the failings of human nature, but which being no vice, is seldom considered either a failing or a misfortune, is what may be called Plito-arborism: that is, a proprietor is so deeply enamoured of his trees, that, though spoiling each other, and many of the principals verging to decay, he cannot find in his heart to condemn them to the axe and put them in his pocket. Thus, many fine trees-indeed extensive woods, are suffered to stand till they are of little value; and, what adds to so serious a loss, is their preventing the gradual rise of young trees to take their place. 
A grove, or hanging wood-that is, a wooded hill which slopes towards the eye and is entirely ornamental-should certainly be thinned with caution; but trees planted as a source of profit deserve no such tenderness; for as soon as they will pay for their occupation of the land, they should be sold to the best bidder.

In the absence of a knowledge of when a tree is about to fail, a very safe rule may be subnitted to the forester, which if attended to in general, no risk will be incurred in having faulty timber left on his hands. When a healthy oak is twenty-four inches diameter at three feet from the ground-ash and elm, larch and Scotch fir are twenty inches diameter at the same height, they may 
LONGEVITY OF TREES.

22.5

certainly be considered as in their prime, and fit for every purpose of the builder. 


\title{
CHAPTER XI.
}

\author{
MISCELLANEOUS.
}

Felcing timber is variously performed: small trees-that is, such as are less than ten inches diameter-are usually chopped down with the axe; but if much larger, it is a bad practice, as not less than a foot of the best of the butt is wasted.

Some writers recommend felling the 
trees by grubbing up the roots, and for the following reasons : a greater length of the bole is obtained, and the roots being got out of the ground at once, saves the labour of grubbing the roots afterwards. But this is a tedious and laborious plan; for the lateral roots must first be laid bare and cut away, and to get at those which trend downwards is attended with the greatest difficulty. The woodman has no power to throw the tree as he may wish, and all the time the workmen are in danger from the uncertainty when or where the tree may fall. Besides, this method is only eligible where the trees stand singly: among others, it is impossible to fell by grubbing without doing much damage to the surrounding trees. And as to splitting up the root more readily when 
lying loose is a mistake; they being much easier got to pieces while in the ground by the usual labour of the rootgrubber。

Felling with the saw is by much the most expeditious and workmanlike method: for by this practice the woodman can throw the tree in any direction with the greatest accuracy. Very little of the useful timber is lost, if the spurs be hewn down level with the surface to form a horizontal plane for the saw to traverse on.

A triangular notch called the fall is made with the axe on that side of the base, and at right angles to the line along which the tree is intended to be laid. The saw is entered on the opposite side to the fall; and when it is worked far enough inwards, a thin wedge 
is entered behind the saw and driven tight to keep the tree steady. Sometimes two wedges are used for this purpose, and which ultimately, when the saw is got to within an inch of the fall, are driven till the tree falls.

The only skill required of the woodman in this mode of falling is, in fixing on the place and cutting the fall in the proper direction. He is guided by having a sufficient opening to receive the head, so that it may fall clear of the neighbouring trees; and he has also to consider whether the head of branches be equally balanced: because if there be many more branches on one side than there are on the other, they, the majority, will swing the tree out of the intended direction in its fall.

Such information is only useful to 
those who are macquainted with the business of felling; but in every part of a wooded country there are men bred to the business of felling timber and underwood, bark peeling, \&c. and who are usually paid by the day. 


\section{FENCING.}

The success of all young plantations of forest trees depends mainly on the efficient manner in which they are fenced. This is so important a part of the proceedings, that it ought to be (after the draining is completed, if such also be necessary) the very first step that should be executed. A deep ditch and hawthorn hedge carefully planted behind, is the best fence for a plantation ; because the hedge grows up with the trees, and 
gives a necessary shelter as well as protection. Posts and rails, or a dead hedge, are often added to serve as a temporary protection until the hedge gets up, which even on good ground does not happen in a shorter period than seven years.

We have often seen plantations of many acres properly and expensively executed, but which being imperfectly fenced, fall a prey to a drove of cattle from sheer neglect. Nor can there be any thing more provoking to an owner than to see the children of his hopes destroyed through a principle of false economy, and only discovered when too late. In all such attempts, there is nothing like doing everything as effectually as possible at first: half measures are rarely successful, especially in such affairs as 
depend for a prosperous issue on a favourable commencement.

Underwoods or coppice are, in the first year after a fall, in the same predicament as a young plantation, and require as much care in the means of defence. On such portions of property the inroads of cattle do immense mischief in a very few hours; and therefore the fencing should always be maintained as completely as possible.

For the protection of single trees, there are many different plans; the square or triangular cradles being the most common. When single trees are planted in pastures, some kind of protection is indispensable; for every new object placed where cattle are, is sure to attract their curiosity, and of which they will certainly make a rubbing-post. 
'The defence, whaterer it is, must therefore be strong enough to withstand this rubbing; otherwise the cradle, tree and all, will be destroyed.

$\mathrm{Mr}$. Pontey, who is certainly one of our best practical writers on arboriculture, but who has umnecessarily swelled, and, in fact, disfigured his excellent instructions by a great deal of severe though pertinent criticism, was perfectly well acquainted with and a close observer of regetable phenomena, although not a profound physiologist. It is remarkable, however, that the want of this portion of knowledge does not in the least vitiate his practical instructions; for they are all perfectly consistent with everything that is known respecting both the physical members and vegetative powers of plants. 
His instructions are not confined to the pruning of trees raised for profit only; he gives directions for pruning ornamental trees also. But this is so nearly allied to the old custom of clipping trees and shrubs into regular shapes, or forms of animals, or architectural objects, that it is only an attempt to revive a ridiculous custom long since exploded. Everybody possessing the least share of legitimate taste must agree that it is impossible to improve by art the natural forms of trees: for whenever a rash hand is put forth to improve a natural form, a fanciful nondescript will certainly be the result.

$\mathrm{Mr}$. Pontey, it is true, only supposes that a rotund lumpy-hearled tree, occupying a station where it is too conspicuous, may have its outline varied by 
disbranching; or that a regular-growing species may be made more picturesque by dismemberment. But all attempts to create picturesque effects, either by the mutilation of natural forms, or by the partial destruction of artificial ones, can yield no real satisfaction to the eye of taste. Such effects can only be caused by the lapse of time or by natural accidents, and, as such, can only attract admiration; but, whatever they may be in themselves, they are not objects for imitation. The irregular disposition of natural forms is allowable for the sake of variety and intricacy; but the mutilation or distortion of them is bad taste.

In the preceding pages, the manner of the growth of dicotyledonous or exo- 
genous stems has been described; but no information has been given why they are so called, or that it is a botanical term used to distinguish them from other stems, which are called monocotyledonous or indogenous.

The first are known by rising from the seed bearing two or more seminal or seed-leaves, called by botanists cotyledons; the second, by the seedling being furnished with only one seed-leaf or cotyledon: the first are exogenousthat is, have the annual additions to the diametric bulk imposed on the outside of that of the last year; the second are inclogenous - that is, all new growth arises from the centre of the stem, and at once gaining altitude and diametric bulk by a central movement and expansion. 
This portion of botanical knowledge is of no use to the British planter, because we have no monocotyledonous trees in our forests. And in tropical forests it is only the singular family of palms which deserve this character. These in certain parts of South America and the East Indies are prevalent, and form extensive and lofty woods; and though their timber is extremely porous and coarse, it is remarkably strong and durable. For the purpose of the builder, the palms are particularly convenient; as they are easily split into quartering, and moreover have not branches, and, consequently, have no knots to weaken their longitudinal structure.

The banboo is another tropical tree belonging to the class $\boldsymbol{M}$ onocotyledoner: in fact, it is only a tree-grass: but its 
hollow jointed stems are remarkably tough and durable, and attain to a great height, and are as useful to the tropical joiner and cabinet-maker as the palms are to the carpenter.

As already observed, we have no hardy trees belonging to this class in Britain. The only genera are herbs; amongst which, asparagus, the leek, the onion, and several bulbous and tuberous flowering plants, are the most common. 

Just Published, price $\mathrm{I}_{\mathrm{B} .}$,

JOHNSON AND SHAW'S FARMERS' ALMANAC FOR 1854.

Bound and Interleaved, as a FARMERS' DIARY, price 2s.

WORKS ON AGRICULTURE,

\&c., \&c.,

PUBLISHED B Y

JAMES RIDGWAY,

169 , P I C CA D I L L Y,

TO ВВ HAD АT THE

SMITHFIELD CATTLE SHOW. STAND No. 44 . 


\section{IMPOR'TAN'T WORKS ON AGRICULTURE, \&c.}

\section{PUBLISHED BY JAMES RIDGWAY, 169, PICCADILLY;}

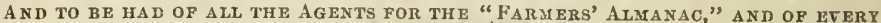
COUNTRY BOOKSELLER IN EVERY MARKET TOWN.

** The three first are excellent Elementary Works for Agricultural and other Schoola, for whon they may be had at 9a. per dozen. They are therefore earueatly recommended to tbe notice of Clerky. mez, and the Directora of Agricultural Estahliabmenta.

\section{I.-AGRICULTURAL CHEMISTRY FOR YOUNG FARMERS.}

By CUTHBERT W. JOHNSON, Esq., F.R.S. 12mo. 1s. 4th Edition.

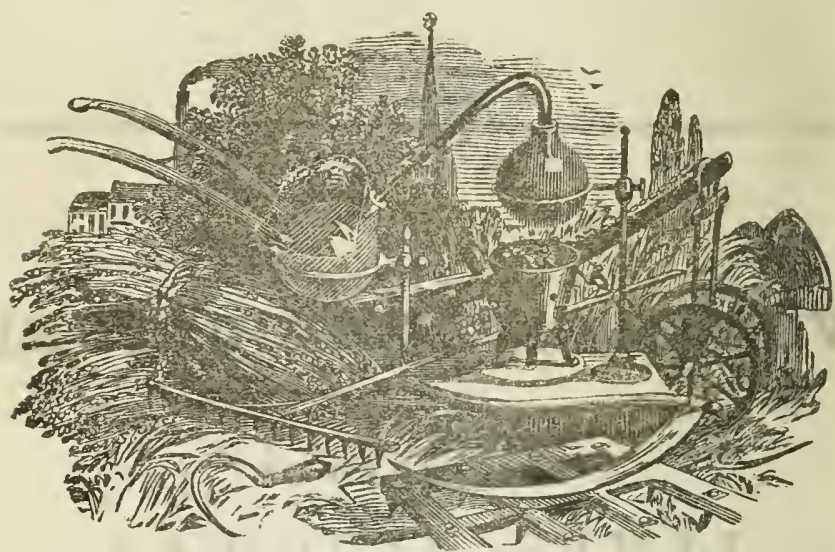

"A paluable littls work, in which the rudiments / derstand, he is referred to the appendix, where the of agricultural chemistry are made familiar enough difficulty is renoved." - Brit. Farmera' Magtor ang capacity Each section is preceded by a "Thia easey we would recommend every farme few questions and answera relating to the subject to read." - Banbury Guardian. "A ahort and treated upon; and in case the reader may meet with clasaified digeat of the realta of Agricultural Cheany chemical term, which he may not clearly un- miatry."-Sussex Advertiser.

AND BY THE SAMB AUTHOR,

II.-THE COTTAGE FARMERS' ASSISTANT IN THE CULTIVATION OF HIS LAND, AND BOOK OF THE HOUSEHOLD. 12mo. 1s. 4th Edition.

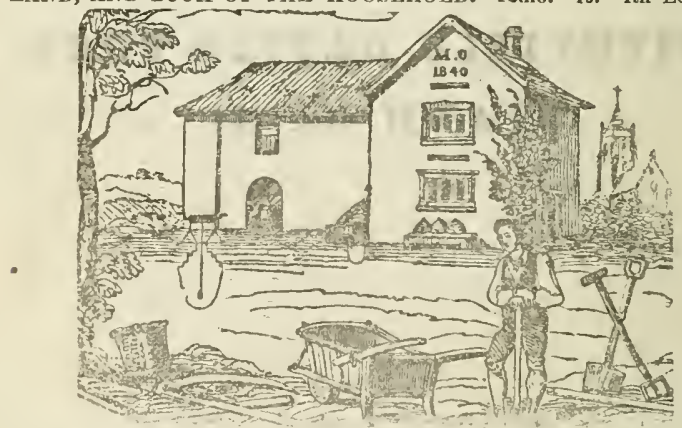

"A Pnluable manual of Lilliputian Furming, ohowing how much mag be made of a little land well tilled. We wish we could reprint the whole, but the work is very cheap. Buy it, landlords, sud give it to gour tenanto; tenants, and giveit to your
labourers."-Brit. Farm. Mag. "Wa have not met for many a day with 60 portable, clieap, and complete a guide hook for the eotteger." -Mark Lane Expreas. 
II1.-A CALEXIDAR FOR YOUYG FARMERS. 1:mo. 1s.

- This contains directions, with copious notes, for the business of the Farm during each nonth of the year.

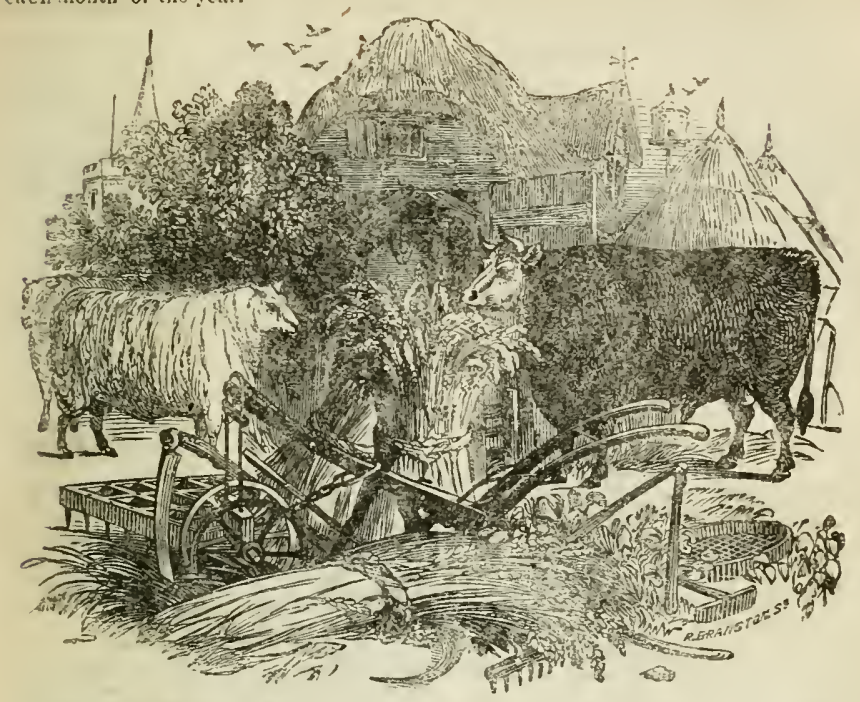

1F. -THE FARMERS' EXCYCLOP.EDIA AND DICTIOYARY OF RURAL AFFAIRS. One thick volume. 8ro. $\mathfrak{2}_{2} 10$ s.

Y.-THE FARMERS' MEDICAL DICTIONARY FOR THE DISEASES OF ANIMALS. Price 6s.

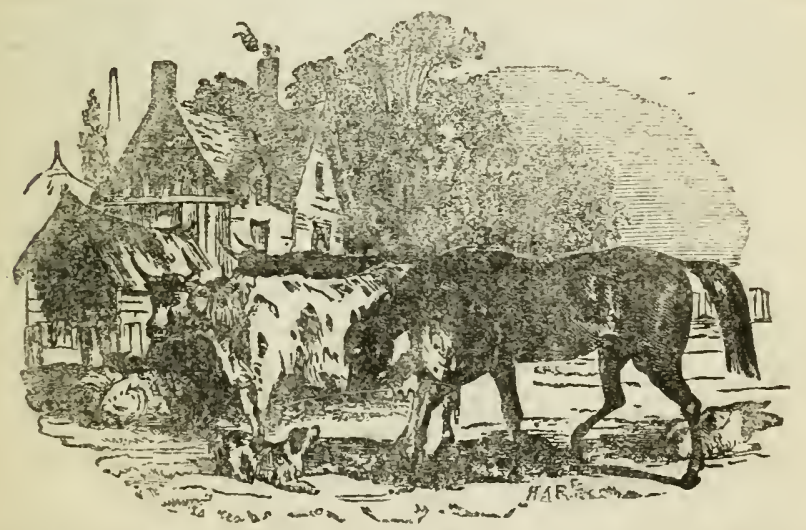

\footnotetext{
"Thi is a very nseful work. It containg a great fully emploged in an extensire practice in the sontb virety of recipes for the cure of the diseases of $\mid$ of England." -Gardeners' Chronicle. "A capital domistic animals, which bave long been success.
} 


\section{Just Published, price Is. Cd., bound in Cloth, the Thirteenth Edition of}

\section{VI.-THE ENGLISH RURAL SPELLING-BOOK,}

irith Easy and Progressive Lessons; intended as an Introduction to the S; elling and Reading of the English Language, and to the First Principles of the Practical and Scientitic Cultivation of the Suil.

\section{By CUTHBERT W. JOHNSON, Esq., F.R.S.}

Illuatrated Alphabet

Common Letterz

Syllables of Twu Letters

Lessun in Wurds of Two Letter's

Words of Three Letters Sentences io Words of

Two or Three Leiters

Words of Two, Three, and Four Letterz

Lessons in Words of One Syllshle, similar in sound

Leasous in Wrorla of One Syllatile, on the uge of $E$ finn]

Lesaong ia Words of One Syllitilo

The Garden

The Cow

The Frtting Pig

The Horse

Bees

The Gate and Fence

The Little Gardener

Worda of One Syllable

Short Sentence日 in

Twords of One Sylla ble

The Plough-Boy

The Little Milk-Miad

The Mill-Maid's Story

The Cow-Boy

The Little Workwoman

F orda of Two Syllablea accented on the First syllable

Good A ir

Weeds

Good Wattr

TAELE OF CONTENTS.

Hoeing

Dirging

Ruking

Plantirus

Potatues

Cabbares

WItent

Take care of the Crumba

A Stiteh in Tint

Conduct is Fate

IIt who will thrire must riae at Five

Idlc People taks the most P:iris

The Ubud Farmer

Trords of Two Syllables, accented on the Second Syllunle

The Doy and the Shadow The Rewnrd of Inhurosnity

A vold Bad Company

Ind ustry and I llemess

Words of Three Syllables, accented ois the First Syllab!e

Be up and doins

The Bull and the Frog Ter Rules for Observancein Ordinary Life

Words of Three Syllables, accented on the Second syllable

The Druver

Gentlenesa to Dumb Anmals

Words of Three Syllables, accented on the Last Syllable

Words of Three Sylla- bleg, pronounced as

Two, ard accented on the First Syllable

The Cotturer's Cuw

The Horge

The Food of the Cow

The Food of the liurse

The Slueep

The Shepherd Ruy

The Dog

The Pig

The Fuod of the Pine

The Barn Duor Fuwl

The Turkey

The Goose

The Duck

Worle of Fuur sylla. bles, accented os the Furst Syliable

Words of Fuur Syliahlea, accessted on the Second syllstle

Travellers see atrange Sirhts

Words of Four Syllables, accented on the Secuud, aud pronounc ed as 'Tliree

Travels round the School-room

Words of Six Syllables

of what use are Worms?

Where do Butterfies come trom?

Proper Names which oc cur in the Holy Bible

Proper Names met with in Modern and $\mathrm{Aa}$ cient Geography

Proper Names occurring in Grecian and $R_{0-}$ man Ilistory

Peracverance

Words sotmnuijug nearly the same, but different in Spelling aud Significestion

Be IIonest in all Thing Of Letters

of Accent and E:1. phagis

Of Capital Letters

Of' Stups and Marks

of Reading

Rules for spelling

Foreign Words atad

Phrages

Latin Words and Phrazes

Common A bbreviation. The Church Catechiam A Catechism of Public Duties

What to do in cases o Danger

\section{Prayers}

Advice to Young Beginnera

Remember

Our Duily Wants

Geography

The Globe

A atronomy

Poetry

A pricultural Chemistr

Chronological Table

Arithmetical Tables

Laroe Hand

Running Hand

Black Letter.

\section{PUBLIC NOTICES.}

"The importance of early preparing youth for the duties which they may lave to fulfil in after life, no one will perhaps be willing to deny. And yet the attempt to commence the aolid toundation of this with the first rudinents of their education has never, till this work appeared, been attempted in a way auitable to the use of all classea. Ot all the employments of mankind, that of eultivating the soil, either in the field or in the garden, is a purauit the most univeraally interesting and refresh. ing. All those wlin have written upon education have seemingly fult the truth of this, nnd have alluded, in some way or other, to the general advantage and pleasure derived from auch purauits. IIrs. A ns. ten long since, when pointing oat the ends of a grood education, described the reaulte of thus early trainin the routhful mind to the exercise and eajoy. ment of the gentle and kindly aympathies, the serse of aelf-respect, and of the respect of fellowmen; the free exercise of the intellectual faculties, the rratification of a curioaity that "grows by what it feeds on, the power of regulatius the habits and busineas of life as as to extract the greatest pasaible portion of comfort out of amall mesns, the refining and tranguillising enjogment of the bentiful in nature and art, and the kindred perceptiun of the beanty and utility of virtue, the strengthening conscionaness of duty fulfilled, and, abuve all, 'the pesce which paseth all understunding.' And when spealsing of the education the best adapted for the wolking classes, MTr. Baptist Noel remarked, that although education is 'nut meant to raise tlie working classes above their coudition, it may greatly multiply the comfort exchanging light, clesn, and cheerful cottages for comfortless cellars; it may give them hetter clothes, better food, and better health; it may deck their windows with finer flowers, apresd cleaner linen on their tables, and adorn their divellingas witis more conrenient furniture.' Such objects the author of the valuable little work which we are now reviewing has very successfully assiated. It is the first great step, we think, in the right path, and will do more to discard from our modern schools the antiquated barbsrissng and imbecilities of by gone generations of 'schoolmasters-like Vyse, Fen. ning, and Mavor-thar say school-buok that has yet appeared. We cheerfully and heartily coxmend it to the perusal of the parent and the teached of youth, not one of whom, we think, will consider that we are wrong in asserting that this "Rural Spelling-book" is by far the best of any that has yet made it a appearance." - The Globe, Oct.29, 18.16

"This," remarks Dr. Lindley (Gardeners" Chronicle for 1816, p. 375 ), "ia an adaptation of the common apelling-book to the special purpose of teaching the rural population uaeful truths while they are passing through the birst process of instruction. As compared with Fenning'a basbarous spelling-book, that now before $u \&$ is im. measurably its superior; and it is not gaying too much to add, that while it ia equal to the last edition of Mavor, it is advantageougly diatinguiahed, even from that, by the usefulness of the aub. jects from which the lessons are taken. To teach children their duty as aervanta or masters, the naturg of the implemeuts, and other familiar ob. jects that aurround them, general fundamental w? ich they enjoy in it. It may preserve them from truths in natural hiatory, good moral maxims ap- 
plicable to the otate of life to which country children eepecially are called; these and similar subjects are what Mr. Jobnson aubstitntes for idle toriee about Mlise Rose being a good cbild, and bow Charles went ont to walk, and all such rem. nants of the days that are gone. We need not aay that wa think his plan a great improvement, and that it is well suited to the inatruction of the raral population."

"The work is very carefully and neatly got up, well printed, and illustrated with very excellent rood engravinga of many of our domeaticated animale, forming in thia reapect a contrast with the worka commonly put in the handa of children. It contains a great deal of useful information, and may be peruaed with advantage by for advanced pupila." -Quar. Jour. of Ag. and Trana. High. Soc, 1846, p. 157 .

"A book peculiarly adapted to the instraction of the cbildren in our village and country achoola. By its nse, the mind of the child will be atored with facts and principles, which will be of grent value to him a he advancea in life, by fitting him for intelligently discharging the duties of his station."-Bell'a Weekly Messenger.

"This work," adds the Editor of the Mark Lane
Exprese, May 25, 1846, "io likely, we think, to ac complish much good in training the youthful mind to an eurly acquaintance with the firat rudiments of the cultivation of the soil. We recommend its perual, therefore, more especially to the farmer, the gardener, the landonner, aod to all who are interested in the welfare of tha risiag generation."

"The author," adda the Ellitor of the Bedford Timea, June 27, 1846, " has carried out his object" admirably. Ilis work is illustrated in a very au perior manner. The animals therein figured an gome wbich hare obtained prizes, and are consi dered almost perfect in form. We have pleasun in recommesding thia cheap little work as bein admirably adepted for youth in the agriculture districts. It is just the apelling-book a farma should put into the hands of his children, and sc that bis labourers' children have it alao."

"It containg more than the average informatio of spelling-books; those portions relating to geography, astronomy, and agricultural chemistry appear to us to be particularly good, and is ad. mirably adapted for country acbools." - Nurfulk Chronicle, Auguat 1,1846.

Just published, price 1s. Ed., bound in cloth,

\section{VII.-THE READER:}

INTENDED TO CONYEY ISEFUL FACTS IN EARLY THEMES FOR CHILDREY.

"The same objects which the author of facts, when teaching even vers small words this little work endearoured to promote in and sentences, keeping constantly in view the 'Rural Spelling Book,' he has steadily the works of God in the phenomena of daily aimed to pursue in the following pages, viz., life, and of the animal and vegetable creato inculcate useful every-day principles and tion."-(Author's Prefacc).

TABLE OF CONTENTS.

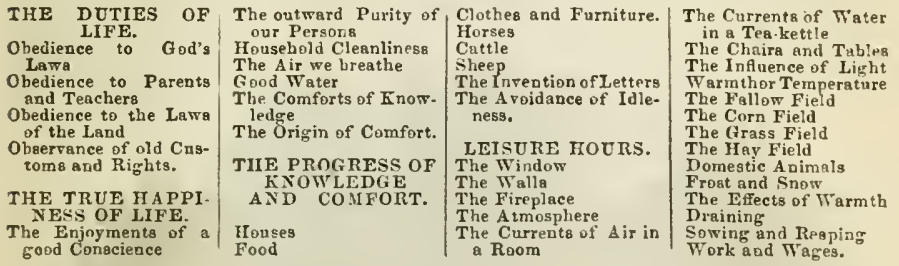

BY TIIE SAME ACFHOR,

VIII.-ON SALTPETRE AND YITRATE OF SODA AS FERTILIZERS.

8vo. 2s.

IX.-ON GYPSUM AS A FERTILIZER.

8 ro. 2s.

X.-UN MANURES APPLICABLE BY THE DRILL.

8vo. 2s.

XI.-ON THE USE OF CRUSHED BONES AS A MANURE. Svo. 3rd Edition. Isi

XII.-ON INCREASING THE DEPTH OF SOILS.

8vo. Is. $6 d$.

XIII-ON INCREASING THE DEMAND FOR AGRICULTURAL LABOUR.

8vo. 1s. 6 d. 


\title{
XIV.-ON THE ADVANTAGES OF RAILIVAYS TO AGRI- CULTURE.
}

2nd Edition. 8vo, 1s. 6d.

\section{XV.-ON THE USES OF SALT FOR AGRICULTURAL PURPOSES.}

3rd Edition. 8ro. 5s.

\section{XVI,-OBSERVATIONS ON THE EMPLOYMENT OF SALT IN AGRICULTURE AND HORTICULTURE.}

13th Edition. 8vo. Is.

\section{XVII,-ON GUANO AS A MANURE,}

\author{
8ro. 1s. 6 d.
}

\section{XVIII.-THE FARMERS' ALMANAC AND CALENDAR,}

For $1841,1842,1843,1844.1845,1846,1847,1848,1849,1830,1851,1852,1853,1854,200$ pp., 1 s., and bound in clotl and interleaved $2 \mathrm{~s}$. Continued Annually. Also, Vol. 1, containing $1811,1842,1843$, and 1844. $12 \mathrm{mo}$., bound in cloth, 4s. $6 \mathrm{~d}$. Vol. 2, containing 1845 and $1846,2 s .6$ d. Vol. 3 , containing 1847 and 1848, 2s. 6 d. Vol. 4 , containing 1849 and 1850, 2s. 6d. Vol, 5, containing 1850 and 1851,2 s. 6 d. And Vol. 6 , containing 1853 and $1 \geq 54,2$ s. $6 \mathrm{~d}$.

By CUTHBERT W. JOH.Tson, Esq., F.R.S., Editor of the Farmers' Encyclopædia, AND

WILLIA M SHAW, Esq.

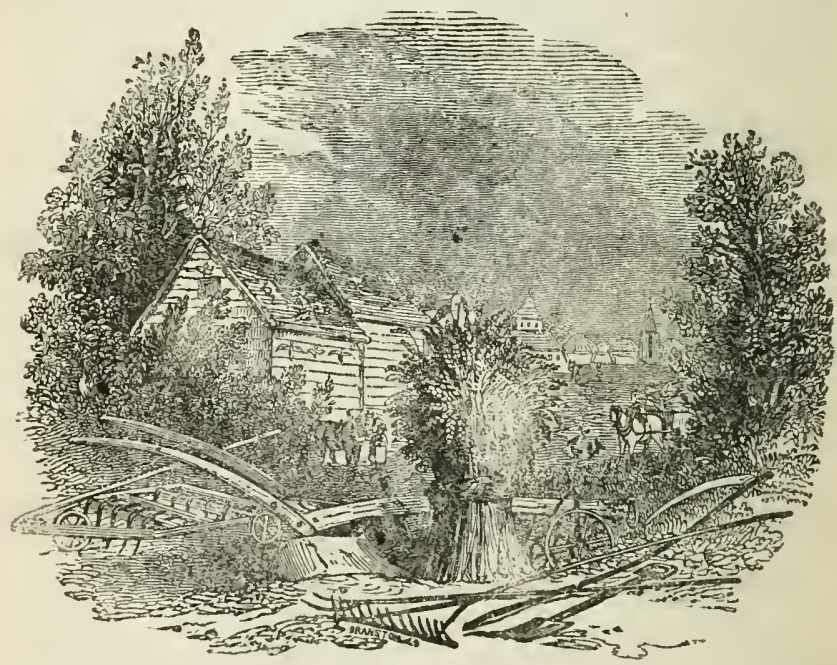

The ALNANAC for 1855 will be published | advertising sheets must be sent by the first on November 1. All adrertisements for its of October, to Mr. RIDGWaY, Piccadilly. 


\section{XIX.-THE PRINCIPLES OF AGRICULTURE.}

By ALBERT D. TIIAER.

Translated by WILLIAM SH.AW, Esq., and CUTHBERT W. JOHNSON, Esq., F.R.S.

In 2 rols. Price 25 s.

AGRICULTURAL IMPROVEMENTs. - It is / sary capital, which should be fixcd at a cerquite oit of the question to expect that the tain sum; and that the farmer should pay farmer will undertake those more extensive. him interest for it, at the rate of ten per imprarements which tend to produce a per-| cent, during the remainder of his lease. manent increase in the value of the land. Nevertheless, the opportunity of making them occurs so often, and the advantage attending them is so obvious, that both parties ought to be disposed to favour the adoption. It might be laid down as a rule, that the landlord should furnish the neces-

Under such an arrangement, the farmer would never propose any improvement, of the utility of which he was not rell convinced; and the landlord would only have to consider whethcr the improvements were likely to be permanently beneficial to the estate. - Tol, i., p. 51 .

\section{XX.-ON THE COTTAGES OF AGRICULTURAL LABOURERS;}

With Economical Working Plans, and Estinuates for their Improred Construction.

By CUTHDERT $\pi$. JOH.NSON, Esq.,

A $: D$

EDWARD CRESY, Esq., Areliteet and Ciril Engineer.

Price 1s, Gd.

"We have much pleasure in inriting the atten- | power of a labonriog man to erect a cottage for tion of our readera to this excellently conceived pamphlet. The anthora, who are practical men, thoroughly conversant with the subject, bnse their artuments upon well authenticated facta, and their recommendations upon admitted natural laws. The chief object of the suthors appears to be the improvement of the moral and phyaical condition nf the agricultural labourer, and we are aatiafied that time will ahow they have not devoted their attention to thia object in vain."-Bell's Messenger, Sept., 1847.

'A very ureful publication, which we heartily recommend to every proprietor of Innded estates. It would form an admirable book for a paroehial ing particnlar methods of carrring them out." himselt on the principles laid down, it ropld be in hia power to clens, drain, and otherwise improve the one which he inhabits. In addition to aound practical advice of this nature, the writers have given very lncid information respect. ing the erection of cobb and pise buildings as practised in Devoushire and on the Continent. The hook also cotains reference to works on Agri. culture and Cottage Building, which woild form useful additions to all clirch and parish librariea.'

-Indian Newa, July 22, 1847. thes $\rightarrow$ sis 'This is a amall pamphlet on a most important subject, adrocating correct principles, and exhibicGardener's Chronicle, Sept. 4, 1847 .

\section{XXI.-THE IMPLEMENTS OF AGRICUL'UUR.}

By J. ALLEN RANSOME.

फith Engravings, in 1 rol., royal 8vo. 9s.

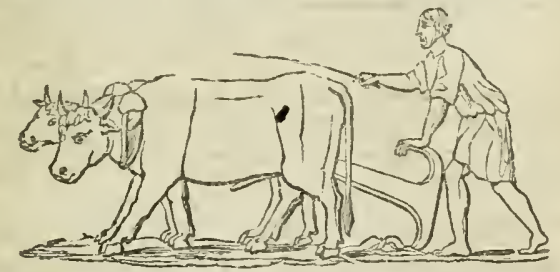

"Thia excellent work will find its way into the library of every farmer." - Mark Lane Exprea. "This is a work possessing no mean pretensions to public favour: the well-known talents of ite anthor, in faet, are the best guarantee that it is replete witi sound practical information. It contains $\mathrm{a}$ well written history of ngricultural implements in past and present nae, with copious comments upon their practical utility, enabling the inquirer to arrive at a correct knowledge of their merits. The rolume contains many well executed wood engravings of every kind of implement. It ia a work that hus long been wanted, and it will find its way inte the hands of every prnetical man. We hardly know which to approve most - the voluable information which it contaies, the result of most laborious research; or

the candonr of the respected anthor, and freedom from a jealons spirit, in dealing with the inventions and improvements of lis competitors. It is a worl which will long redound to the credit of the great firm of Ransome \& Co,, in which the author is a pnrtner."-Ipswich Jonrnal. "From no hands could anch a work have better emanated." -Norwich Mercury. "The intereat of such a not confined to those concerned in the cultivation of land-readers of all claspes may derive information, and information of interest too, from this volume." - Norfolk Chronicle. "Upwards of 160 hirst-rate angrarings of implements are intersnersed throyghout the book. We hartily recommend it." -Brit. Parm. Mrys. "A work ahounding in use. ful practical unatter." - Farmera' Magazine. 


\section{XXI.-ON AGRICULTURAL FERTILIZERS.}

By CUTHBERT W. JOHNSON, Esq., F.R.S.

Third Edition. Price 8 s.

Being a complete History of the various KIN vS oF MANURE, with a Description of the Jand to which each is adapted, and the best means of application.

\section{XXIII.-THE NATURE AND PROPERTY OF SOILS,}

And the best Means of permanently increasing their Productiveness; and on tlie Rent and Profits of Agriculture, with a full Account and Plan of the Proceedings at Whitfield Example Farm, \&c. By JoHn MIORTON. Price I0s. Fourth Edition, enlarged.

New Edition. Now ready, with many Coloured Plates, after Nature, price 30 ,, cloth boards, forming 1 vol., 8vo.,

\section{XXIV.-SINCLAIR ON THE GRASSES;}

To which is added, for the first time, THE WEEDS OF AGRICULTURE.

By Mr. SINCLAIR and Mr. HOULDITCH.

This desirable rolume coutains an Account | mous expense, and during a series of years, of all the Experiments tried at Woburn Abbey by Mr. Sinclair, uncter the direction of His Grace the Duke of Bedford, at an enoras to the mutritious qualities of each particular grass, and showing to what kind of Soil and Purpose each is best adapted.

XXV.-ON THE ADVANTAGES OF BONES AS A MANURE. Price 2s.

\section{XXVI.-ON MANGEL-IVURZEL AS A FALLOW CROP.} Price 6d.

\section{XXVII. - A POPULAR TREATISE ON AGRICULTURAL CHEMISTRY.}

Intended for the use of the Practical Farmer. Dy Charles Squarey. Price 5s.

"The writer of this little work has succeeded, popular work has our himhest commendation, with great skill and ability, in simplifying a sub. ject generally considered too ahstrise for a larce portion of the agricultura] body. *** * Thia

\section{XXVIII.-MAIN'S YOUNG FARMERS' MANUAL.}

Showing the Practice and Principles of Ag- information on the first principles of Agririculture as applicable to Turnip Land Farms. 'culture is an object, and those nore aclPrice 6s. Second Fdition.

"This most useful little book should be many useful hints." carefully perused by every person to whom

\section{XXIX.-MAIN'S PLANTER AND PRUNER'S ASSISTANT.}

Giving every possible Instruction for the planting, Rearing, Pruning, and general Uanagement of every kind of Forest Tree; witl Practical Hints on the clioice of Soil, situation, \&c. Illustrated with many explanatory Plates. Price 6s. Second Edition.
"A most important work, and wortliy every landowner's attention, and would le ad rantageously placed in the hands of every Bailift' and Woodman in the kingdom."

\section{XXX.-REMARKS AND SUGGESTIONS ON THE SYSTEM} OF FARMING ADAPTED TO THE CLIMITF AND SOIL OF THE COUNTY OF CARMARTHEN. 


\section{XXXI.-ON THE IMPROVEMENT OF LAND AS AN} INVESTMENT FOR CAPITAL.

By Joshua Trinuer, F.G.S., Author of Practical Geology and Mincralogy, Practical Cliemistry for Furmers and Laudowners, \&c. \&c. Price ls.

\section{XXXII.-A LECTURE ON THE SCIENCE AND APPLICATION OF MANURES.}

By the Rer. A. Huxtable, Rector of Sutton Waldron, Dorset. Sirth Edition, will a Preface, ls.

\section{SXXIII.-ON LAND DRAINING AND IRRIGATION;}

And on the Application of Drainage Water as a Motive Power to Machinery, for Agricultural Purposes.

By E. Leader Wrlirass, C.E.; Acting Engineer to the Severn Company. Price Is. 6 l.

\section{XXXIV.-AN ESSAY ON TROPICAL AGRICULTURE.}

By Lovell Philips, M.D. Price 3 s.

\section{XXXV.-ELLIOT'S FARMERS' ACCOUNT BOOK.}

Being the result of many years' extensive Illustrated by a Micliaelmas Valuation, practice. By Double Entry in one book. and a Wcekly Account. Price 16s. for one The arrangements are clear and concise, printed and ruled ready for filling up, under the heads of Day Labour, Task Labour, Bills, Debts, Owing and Owed, Live Stock, Green Crops, Corn, Hay, and Straw, Rent, year, and $9 \mathrm{~s}$. for a half sear.

"No farmer desirous of knowing the exact state of his expenses, ouglit to be withcut this work.",

Taxes, Cash, \&c.

In 247 closely printed octavo pages, Second Edition, price 2s, 6d., XXXVI.-KEY TO AGRICULTURAL PROSPERITY.-STATE AND PROSPECTS OF BRITISH AGRICULTURE.

Being a Compendium of the Fvidence/. "Only let Mr. Iutt's pamphlet find its way given before a Commitee of the House of into the farmer's houses of England, Scotland, and Commons, appointed in 1836, to inquire into Ireland, and the delusion of a quarter of a century Commons, appointed in 1836, to inquire into will vanish in another year from all capable and Agricultural Distress, with a few Introduc- dispassionate minds." "New Monthly Magazine. tory Observations. By Wizlias HUTT, "We trust it will be extensively circulaled Esq., M.P.

\section{XXXVII,-TIE, FLAX INDUSTRY;}

Its Importance and Progress: also its Cul- Flax Society, and a word on Chevalier tivation and $\mathrm{M}$ anagement, and Instructions in the various Belgian Methods of Growing and Preparing it for Market, with Extracts
from the Annual Reports of the Rosal Irish
land. Price 5s. from the Annual Reports of the Rosal Irish land. Price 5s.

\section{XXXVIII.-ON FARM BUILDINGS.}

With a Few Okservations on the State of Agriculture in the County of Kent. By TIsconnt Torringtox. Price 5s. Second Edition.

\section{XXXIX.-THE TURNIP FLY: THE MEANS OF ITS PREVENTION.}

Founded on retur'ns from upwards of One Hundred Gentlemen, farming in England and Wales. Price 2s. 6d. 


\section{XL.-THE MODERN DAIRY AND COWKEEPER.}

By CUTHBERT W. JOHNSON, Esq., F.R.S.

\begin{tabular}{|c|c|c|c|}
\hline $\begin{array}{l}\text { lie Cors-her Breed and } \\
\text { Points } \\
\text { he Treatment of a Cuw } \\
\text { leanliness }\end{array}$ & $\begin{array}{l}\text { Food } \\
\text { Land required for } \\
\text { Dizeases of Mfilking } \\
\text { The Suckling Calf }\end{array}$ & $\begin{array}{l}\text { The Dairy } \\
\text { The Cowhonse } \\
\text { Milk and Butter }\end{array}$ & $\begin{array}{l}\text { Cheese Making-in Che- } \\
\text { shire, Stilton Cheese, } \\
\text { \&c., \&c. }\end{array}$ \\
\hline
\end{tabular}
The Suckling Calf

"Mr. Cuthbert W. Jolnson, the author of this little work, is so welj known in the agricultural world, that the bare mention of his name is a suffcient guarantee for the practical value of the contents of the volume. Mr. Johnaon at no time hesitatea to afford a respectful attention to any new sugrgestions for improvement in the various departments uf agricultural science and art, but he at the same time gives more especial heed to his own, and the experience of otlier men of real judmment and discretion, and his writings may therefore at any time be depended upon as records

of priziples which have been duly tested, and not of untried theory. To the "Modern Dairy and Cowkeener' these remarks are in every respect applicable; and the Engligh farmers and house. keepers, for whom it is written, may place inaplicit confidence in the instructions it supplies. The yrincipal heads which Mr. Johnsonthere discuszes are the breed and points of the Cow; her treat ment as to cleanliness, food, and diseases; the sucking calf; the dairy, and cheese-making. The book is illustrated by some finely executed portraits."-Norfolk News, Aug. 17th, 1850.

\section{XLI.-HODGES ON DRAINING.}

The Use and Advantages of Pearson's Draining Plough. By Trosras LAT Hodges, Esq., M.P. Price 1s.

\section{XLII.-ON UNDER-DRAINING WET AND COLD LANDS.}

By Robert Green, Farmer. Price 3s. 6d.

\section{XLIII.-A SYSTEM FOR. MANAGING HEAVY AND WET} LANDS IVITHOUT SUMMER FALLOWS.

Under which a considerable Farm in Hert- | tracts from some Letters written by the Earl fordshire is kept perfectly clean, and made of Thanet, proving the infallibility of the productive. By Thoss Greg, Esq. Fourth plan, as presented to the Board of AgriculFdition. With an Appendix, pointing out ture, and now published at their request. how the infant Turnip may be protected Price 3s. 6d., with Plates.

from Insects. To which are added, Ex-

\section{XLIV.FINLAYSON'S BRITISH FARMER AND PLOUGH- MAN'S GUIDE.}

Post 8vo. Second Edition. Price 9s.

\section{XLV.-ON IMPROVED SHORT-HORNS, AND THEIR PRE- TENSIONS STATED.}

By the Rev. Henry Berry. Price 3s. 6d.

\section{XLVI.-THE FARM-SCHOOL SYSTEM OF THE CONTINENT,}

And its Applicability to the Preventive and Reformatory Education of Pauper and Criminal Children in England and Wales.

By Josepri Flatcher, Esq., Barrister-at-Law, Her Majesty's Inspector of Schoo's, Honorary Secretary to the Statistical Society of London, Scc. Price ls.

Price 1s.,

XLVII.-A REPORT ON FEEDING STOCK WITH PREPARED FOOD.

By Josepu MLARHaLt.

\section{Price Is., \\ XLVIII.-CHEESE COLOURING.}

An Essay showing the Inutility and Mischiof of the Practice, and Advising its Disuse in the Dairy.

Price One Slitling,

XLIX.-PERUVIAN AND BOLIVIAN GUANO;

With Practical Instructions for its Use, and Trstimonials of its Properties and Results. 


\section{Price Three Shillings, \\ L. - PRACTICAL OBSERVATIONS ON THE IMPROVE- MENT OF BRITISH FINE WOOL, \\ And the National Advantages of the Arable System of Sheep Husbandrs.}

By J.K. TRIMMER.

LI. - A WORD IN SEASON; OR, HOW THE CORN GROWER MAY YET GROW RICH, AND HIS LABOURER HAPPY.

Addressed to the Stout British Farmer. Twelfth Edition; with a few Hints about ROUT CROPS. Price is.

With full Directions for enrrying out the plan of Growing Wheat.

Price Sixpence.

LII.-TEN MINU'IES' ADVICE TO LABOURERS.

Sixth Edition, with Additions.

LIII. - AN ATTEMPT TO ESTIMATE THE EFFECTS OF PROTECTING DUTIES ON THE PROFITS OF AGRICULTURE.

(Important Pamphlet.)

By Johw Mortox, F.G.S., Joshua Timmer, F.G.S. Price 2s.; and Supplement, Is.

LIV.- IVARNES ON THE CULTIVATION OF FLAX. THE FATTENING OF CATTLE WITH NATIVE PRODUCE; BOX-FEEDING; ON SUMMER GRAZING.

Second Edition. 7s. 6d.

\section{LV.-BAXTER'S LIBRARY OF AGRICULTURE.}

\section{Fourtl Edition.}

Contairing Farming - Breeding-Grazing-Dairy Management-Gardening and Rura] Affairs, and every Modern Improvement in Husbandry.

Price 2s. 6d.,

LVI.-HEWETT DAVIS'S FARMING ESSAYS.

CONTEXTS-

On Selecting a Farm

Farm Leases and 'Tenant's Fights

Artifieial Manures

rlick and Thin Soring

Spring Park Farming
Agriculture, Ancient and Modern

Deep Drainage of Arab'e Land

General Direetions for Draining

Kohl Rabi and French sheep

LVII. - A PRACTICAl, TREATISE, EXPLAINING THE ART AND MYSTERY OF BREWING PORTER, ALE, TWOPENNY, AND TABLE-BEER.

Intended to reduce the Fxpenses of Families.

By Sayuel Childs, Common Brewer.

Fourteenth Edition, Is.

* Upwards of Twenty Thousand of this little Tract hare been sold.

Seventh Edition. 1s.

LVIII.-THE PRESENT PRICES.

By the Rev, A. Huxtable, A.MI. 
Just published, the Thirteenth Edition of

\section{LIX.-WARREN'S FARMER'S ACCOUNT BOOK,}

Introduced at the Grand Agricultura] / sanction of the most scientific AgricultuMeetings at Cambridge, Livernool, Bristol, $\left\{\begin{array}{l}\text { rists, who aftirm it to be the most simplificd } \\ \text { rime }\end{array}\right.$ and Derby, and sanctioned by the principal and yet correct Account Book extant: and Agricultural Gentlemen and Farmers.

Nothing is calculated to prove the value of any work equal to a rapid sale. This Account Book has now reached the Thirtenenth EDItion; and during the publication the Publisher has received the by a small portion of their daily attention, their accounts are so correctly and methodically arranged as to ascertain, at a minute's notice, the produce of every article of Live and Dead Stock, and also the various expenses of their farm.

\section{LX.-FARMER'S ACCOUNT BOOKS.}

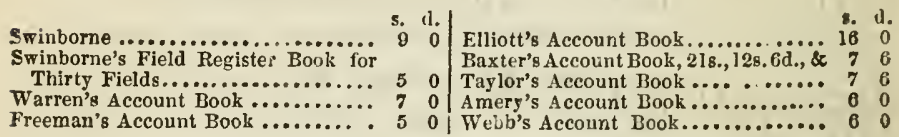

Price 3s. 6d.

LXI.-PRIZE ESSAY ON LINCOLNSHIRE EARMING.

By J. A. CLARKE.

\section{LXII.-PRACTICAL OBSERVATIONS ON THE CULTURE OF BEET ROOT.}

By James Reeve. Price ls.

LXIII.-PLOUGHING BY STEAM.

By LoRd WILLNGGB Dr ERrsat. Price 2s. 6 d.

\section{LXIV. - JOURNAL OF THE ROYAL AGRICULTURAL SOCIETY OF ENGLAND}

FROM TIE COMMENCEMENT.

Price $3 \mathrm{~s}$. 6d.

LXV. - THE COMPOSITION OF HYDROGEN AND THE NON-DECOMPOSITION OF WATER DEMONSTRATED.

By W. F. Stevenson, F.R.S., F.S.A.

Second Edition, revised, with Important Additions.

In 2 vols., witl Plates, price 30s., New Edition.

DARTILI'S FNGLISH RACE-HORSE.

LXVI.-A TREATISE ON THE CARE, TREATMENT, AND TRAINING OF 'THE ENGLISH RACE-HORSE;

Witl Important Details applicable to bettering the condition of Ilorses in genera]. By R. DARvilu, V.S. to the Seventh Hussarg.

"Never before was such a book written in nny languare, so replete with those minute but indis. pensable particulars of practice, and by a writer Who has personally performed his part throughout the whole of the practice. This is the true book

of reference for erery stud and training proom, and every jockey."-Vide Lawrence on the Horse, p. 297 ; ulso, The Sporting Magazine and British Farmer's Magazine. 


\section{SPLENDID BOTA NICAL WORKS}

\section{NOW PUBLISHING BY RIDGWAY.}

\section{LXVII.-DR. LINDLEY'S SERTUM ORCHIDEUM,}

A Wreath of the most beautiful Orchilaccous Flowers, complete in $10 \mathrm{Parts}$, at $25 \mathrm{~s}$. each, splendidly coloured.

$\because$ An early application is respectfully solicited for the few remaining unsold copıcs,

the Work cannot be reprinted.

\section{LXVIII.-LADIES' BOTANY.}

By Dr. Lryder, Editor of the "Botanical Register," "Fossil Flura of Great Britain," \&c. Fourth Edition. 2 vols. 810., with numerous plates, fincly coloured. $25 \mathrm{~s}$. each rol. coloured, and 16s. plain.

"We consider it quite needless to recommend this work; it must find its way into the library of erery lady, and it ought to be in the coat pocket of every young gardencr."-Gardener'a Magarine.
"Let it be known-let it be introduced nto erery library, reading-room, and seminary throughout Britain; let it become the clasa-book of bo. tanical study."-Horticultural leegiater.

N.B.-An Abridgment of this beautiful Work, illustrated with Wood-cuts, for the use of Schools and Young persons in general, is now ready for delivery. Price 6s. bound in cloth.

To Amateurs of Flowers. In I vol., 2nd Edit. price 6s., coloured, in cloth,

\section{LXIX.-THE FLORIST CULTIYATOR;}

Or, Plain Directions for the Management of $\mid$ which is added, the Monthly Operation usual the principal Florist Flowers, Shrubs, \&c., for the Flower Garden, Shrubbery, and adapted to the Flower Garden, Shrubbery, Green-house. The whole arranged on a plan and Green-house; with select Lists of the different from any work hitherto published. finest Roses, Geraniums, Carnations, Pinks, By Thomas WirLats, Esq., Amateur Cul Auriculas, Polyanthuses, Tulips, Dahlias, tivator.

Heartsease, Cistus, or Rock Rose, \&c. To

In 3 vols., with 230 Copper-plate Engravings, price $£ 6$ 12s., LXX.-THE FOSSIL FLORA OF GREAT BRITAIN;

Or, Figures and Descriptions of the Veget-|F.R.S. L.S and G.S., \&c., \&c., and WiLable Remains found in a Fossil State in Lias HuTtox, F.G.S., \&c.

this Country. By JoHN LrNder, Ph. D.,

\section{LXXI.-BOTANY ABRIDGED.}

For the Use of Schools and Young Persons. Illustrated with numerous besutiful Wrood Cuts, \&c.

By Professor Limdley. Price 6s.

\section{LXXII.-SWEET'S HORTUS BRITANNICUS.}

Second Elition; one large rolume, 8ro, E1s., bound in cloth.

A Catalogue of all Plants known, cultivated in the Gardens, or indigenous to Great Britain, arranged according to the natural order to which they belong, with the addition of the Linnxan Class and Order to each genus, and the Colour of the Flowers; the whole brought down to the present time. By GEORGE DON, F.L.S.

P.S.-The only complete Catalogue of Plants without Supplements.

It certainly is the most complete and useful catslogue that hss yet oppesred, as, in one line, it gives the aystematic and English uames, where deacribed, of what country it is a native, the year introduced, the months when in flower, whether hardy or tender, its duration, and reference to the books in which, it is figured; snd where any names have been lately changed, a synonyme ia given in italics, to show what it is changed from. It also contains nearly double the number of plants contained in any other catalogue that we plants conso that, on the whole, we believe it could not have been more complete. In our opinion, the arrange. ment according to the natural syatem is far preferable to that of an artificial one, particularly for cultivators; and on this account the present work ahould be in the hand of all gardenera and cultivs. tora of plants; and the reference to the figureswill also render it very useful to the botsnist." - Gen tleman'a Mfugraine. 
Sixth Edition, in one large 8 vo volume, 16s. cloth boards,

\section{LXXIII._SWEET'S BO'TANICAL CULTIVATOR; OR, HOT- HOUSE AND GREEN-HOUSE MANUAL.}

Giving full Practical Instructions for the management of all the Plants cultivated in the Hothouses, Green-houses, Frames, and Borders, in the Gardens of Great Britain; with Plain Directions for the Management of Bulbs and Plants in Rooms, \&c. By ROBERT SwEET, F.L.S.

"Indeed, what Mr. Sweet has said on the culture of bulbs and epiphytes, in the last edition of his 'Botanical ' Cultivator,' may be conaidered aa the ultimatum on this suluject for the British gardener." -Gardenera' Magazine.

* * This Edition corresponds with the new edition of "Sweet's Hortus Britannicus," and contains, for the first time, Genus "Orchidaceæ."

Dedicated to the Patrons and Patronesses of Village Schools.

\section{LXXIII.-A CATECHISM OF GARDENING.}

Intended for the Use of Viltage Schools and Cottages, containing Plain and Brief Directions for cultivating every kind of Vegetable in common use.

By an Old Practrtioxer. Second Edition, enlarged. Price Is. 6d.

6i This is a chesp little work, and far better adapted for its arotred purpose than any of the tracts which have preceded it. The small type and closely printed pare of the Catechism ahow that the Anthor is perfectly serious in his wish to extend a knowledge of IIorticulture to the bum- blest classes of Society."-Loudon's Garlener" Magazine.

"This ia not only a useful, hut a cheap publication, and excellently adapted for ita purpose.' -Analyst.

In 8ro., with Plates and Plans, 6s., or 9s. finely coloured,

\section{LXXIV.-THE LANDSCAPE GARDENER;}

Comprising the History and Principles of Tasteful Horticulture. By the Rev. Prebendary DENIIS.

"But taste, like erery other quality of the mind, may be nurtured into excellence; and Mr. Dennis has ahown himself well qualified for the task of unfolding it; and, to use the phrage of the celebrated Landscape Gardener of the last century, with whose name he is familiar-making the moat of its capability." - Horticultural Journal.
"The present work ahounds with original obserration, and is well worthy of a place by the side of the most esteemed publications on the principle of Landscape Gardening.-Horticultural Journal recond notice."

\section{LXXV.-THE FRUI'T GROWER'S INSTRUCTOR.}

By G. BuIss, Nurseryman.

A Practical Treatise on the Management of Fruit Trees, from the Nursery to Maturity; with directions for the erection of Forcinghouses, Frames, \&c.; and Lists of all the best Fruits, adapted both for Forcing and the Open Ground, showing the most improved methods of every kind of Cultivation.

"The directions for the management of the apple are excellent, as far as they go; and among the uatructions for forcing there are many things that a gardener will do well to attend to carefully, for in thore parts of the work the real experience of a good enltivator is manifest." -Gardeners' Chron. "In the 'Fruit Grower'a Instructor' the author delivers the result of his own practice, and his nrellacquired reputation is an ample guarantee for the reliance that may be placed upon his judgment and experience. The directions for building hot-houses are extremely judicious; much original information is given upon a subject on which such information was much called for; it will not, therefore, fail to attract the attention it deserves."-Gardeners' Gaz.

\section{Price One Shilling,}

\section{LXXVI.-PERSONAL SAFETY FROM LIGHTNING, \&c.}

Directions for ensuring Tersonal Safety during storms of Thunder and Lightning; and for the right application of Conductors to Houses and other Buildings. By JoHN LEIGH, Jun., Esq. Third Edition.
"The whole of the little tract being of that plain, sensible, and accurate character, as partica. larly to eulinhten not only the ignorant peasant, but the public in general, as to the best ascertained means of escaping destruction, or damage, from thunder storms."-Monthly Reviow, Mayl. 


\section{LXXYII.-THE SPEECHES OF THE RIGHT HON. GEORGE CANNING,}

Corrected and revised by himself, with Menoirs of his Life; illustrated by a fine Purtrait, Fac-similes of his Hand Writing, a Plate exhibitive of his mode of correcting and revising his speeches, \&c., in two important passages in the celebrated one on Portugal. 6 rols. 8 ro. 3rd Edition. $£ 312 \mathrm{~s}$.
The late Richt Hon. IV. Huskirson, in a Lette to the Eititor, alludine to the Work, gays, "It is a Work which is destined tu convey to posterity the remains of his splendid talents as an oratorto exhibit his principles as a atatesman-and to show with what energy and ouccess he carried those principles into execution as a Minister if the Crown."

\section{LXXVIII.-LORD COLLINGIVOOD'S MEMOIRS AND COR- RESPONDENCE, PUBLIC AND PRITATE.}

By G. L. Newnhas Collixgwood, Esq., F.R.S. Fifth Edition. 2 vols. 12mo., with Aduitional Letters.

"The portrait of one English wortlyy more is "Having thus referred to Lord Collingrood" now secured to posterity."-Quarterly Keriew. "We do not know when we bave met with so delightful a book as this, or one with which we are so well pleased with ourselves for being deits moral beauty."-Edinburgh Review.

Life, 1 may be allowed to say, that the publication of that rolume is indeed a national good $;$ it ought to be in every afficer's cabin, and in every statesman's cabinet." - Southeg'a Life of Lord Nelson, New Edition, p. 319.

New Edition, in 4 vols. Price $f 22 s$.

\section{LXXIX.-THE SPEECHES OF THE HONOURABLE THOMAS ERSKINE,}

(AFTERWARDS LORU ERSKINE),

When at the Bar, on Subjects connected with the Liberty of the Press, and against Constructive Treason. 4 rols. 8vo. With a Portrait and Preface by the Right Hon. Lord Biougham.
"Wo take the opinion of the coutry and I every part of the world, where the language is understood, to be that of the most unbounded admiration of these exquisite specimens of Judicial Oratory, and of a preat obligation to the Edicir of the collection."-Edin. Review, vol. xix.

\section{THE NEW PARLIAMENT.}

Price 3s.

\section{LXXX. -THE PARLIAMENTARY MANUAL FOR THE YEAR 1854 ;}

Containing the present and last Parliaments, | Parliaments. Also, a List of the Changes authentic results of the various Polls in in Administration, from the CommmenceEngland, Wales, Scotland, and Ireland; ment of the present Century; a Summal'y and a Summary of the Act 2 William IV., Account of the Duties of the great Officers cap. 45. To Amend the Representation of of State; a Tahle of the Duration of the the People in England and Wales: with several Parliaments, from Henry VIII. to Forms of Lists and Notices, applicable to the Piesent Time; a List of those places Counties, Cities, Boroughs, \&c. To which which formerly sent Members to Parliament; are prefixed a List of the Present and Past | and a complete Abstract of the Election Laws.

Third Edition, with a Plate and two Diagrams. 1s. or ls, 6d, bound and gilt,

\section{LXXXI.-WHAT IS A COMET, PAPA?}

Or, a Fantiliar Description of Comets; more Heavenly Bodies. By Rosina MARIA particularly Halley's Comet. 'To which is ZORNLIN. prefixed a Concise Account of the other

Or, The Two Alinanacs; containing more Inquiries in Astronomy. Plate and Diagrams. 1s., or is. 6 d. bound and coloured.

MR. RIDGWAY has on Sale a large supply of Torks on MODERN AGRICULTURAL IMPROVEM ENT.

- Various Works on MODEL COTTAGES for AgRIColteral LABourers, and AGRICULTURAL BUILDINGs', \&c., \&c., \&c. 
Also to be had of RIDGWAY.

YOUATT'S COMPLETE GRAZIER............................. 0180

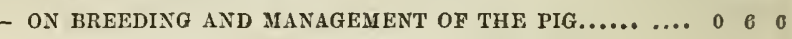

- ON SHEEP..................................... $08{ }^{2} \quad 0$

- ON CATTLE....................................... 080

- ON THE HORSE ................................... 0100

STEPHENS' BOOK OF THE FARM. 2 Vols., and Edition .............. 300 LOW'S PRACTICAL AGRICULTURE......................... I 1 c

MANAGEMENT OF LANDED PROPERTY.................. 1 l 0

BAYLDON ON VALUING RENTS, \&c., \&c. ...................... 0 lo 6

CAIRD'S ACCOUNT OF ENGLISH AGRICULTURE.................. 0140

STEWART'S STABLE ECONOMY............................ 0 \% 6

STEPHEXS ON IRRIGATION AND DRAINING .................. 0 \% 8

TULL'S HUSBANDRY. Preface by WM. COBBETT ................... 0150

BROWN'S FORESTER ................................... 1 10 .

BRITISH HUSBANDRY. 2 Vols. With C. W. Jounsox's Supplement..... 0160

THE FARMER'S MIONTHLY MAGAZINE ....................... 020

THE BRITISH FARMER'S QUARTERLY MAGAZINE............... 0 \% 0

THF HIGHLAND SOCIETY'S QUARTERLY JOURNAL OF AGRICULTURE 0 S 8

BLOWN'S FARMER'S ANNUAL ACCOUNT BOOK ................ 0 6 6

RHAM'S DICTIONARY OF THE FARM ........................ 046

London : Printed by Rogerson \& TuxForD, 246, Strand. 



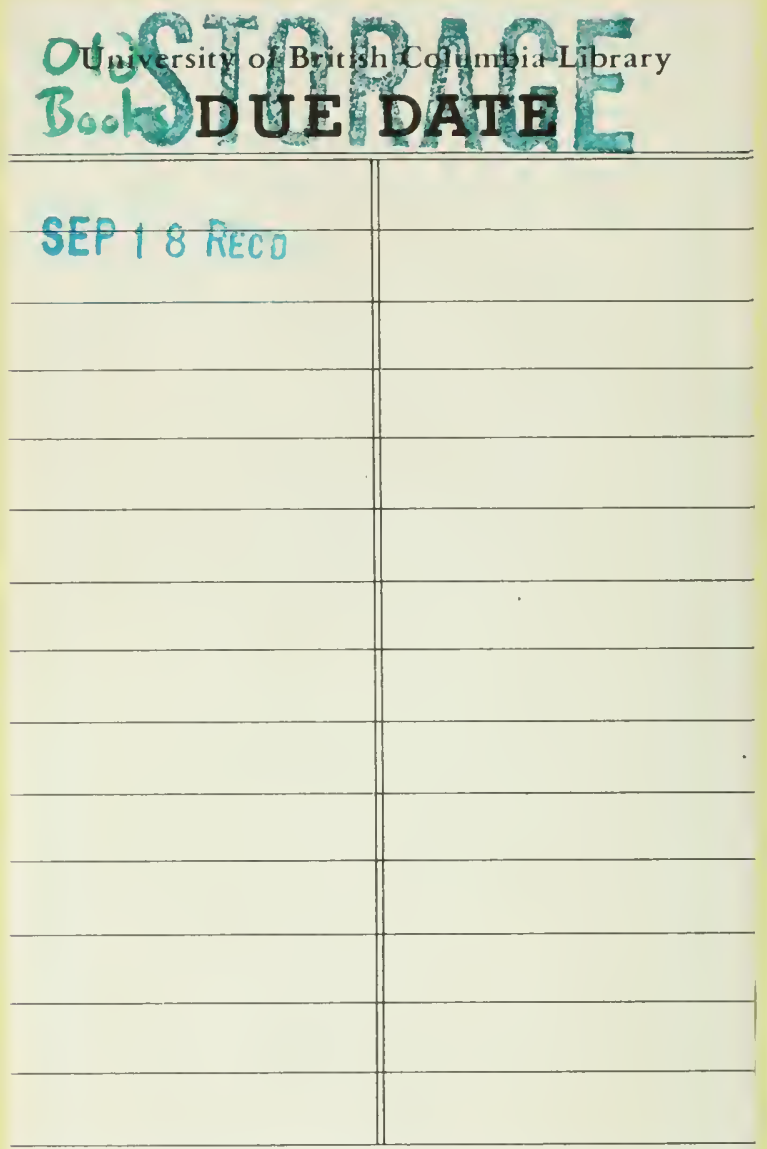

FORM 310 
